Florida International University

FIU Digital Commons

$11-14-2019$

\title{
How Does the Work of the Negro Youth Study (1937-1941) Fit into the History of the Social Sciences?
}

Randall Haines Kaufman

rkauf001@fiu.edu

Follow this and additional works at: https://digitalcommons.fiu.edu/etd

Part of the Scholarship of Teaching and Learning Commons

\section{Recommended Citation}

Kaufman, Randall Haines, "How Does the Work of the Negro Youth Study (1937-1941) Fit into the History of the Social Sciences?" (2019). FIU Electronic Theses and Dissertations. 4314.

https://digitalcommons.fiu.edu/etd/4314

This work is brought to you for free and open access by the University Graduate School at FIU Digital Commons. It has been accepted for inclusion in FIU Electronic Theses and Dissertations by an authorized administrator of FIU Digital Commons. For more information, please contact dcc@fiu.edu. 


\title{
FLORIDA INTERNTIONAL UNIVERSITY
}

Miami, Florida

HOW DOES THE WORK OF THE NEGRO YOUTH STUDY (1937-1941) FIT INTO THE HISTORY OF THE SOCIAL SCIENCES?

\author{
A dissertation in partial fulfillment of the \\ requirements for the degree of \\ DOCTOR OF PHILOSOPHY
}

in

HIGHER EDUCATION

by

Randall Haines Kaufman

2019 
To: $\quad$ Dean Michael R. Heithaus

College of Arts, Sciences, and Education

This dissertation written by Randall Haines Kaufman, and entitled How Does the Work of the Negro Youth Study (1937-1941) Fit into the History of the Social Sciences?, having been approved in respect to style and intellectual content, is referred to you for judgment.

We have read this dissertation and recommend that it be approved.

Norma Goonen

Kenneth Lipartito

Daniel Saunders

Benjamin Baez, Major Professor

Date of Defense: November 14, 2019

The dissertation of Randall Haines Kaufman is approved.

Dean Michael R. Heithaus College of Arts, Sciences and Education

Andrés G. Gil

Vice President for Research and Economic Development and Dean of the University Graduate School

Florida International University, 2019 
(C) Copyright 2019 by Randall Haines Kaufman

All rights reserved. 


\section{DEDICATION}

I dedicate this dissertation to my parents (z"l) who are not able to see the end of my 43-year odyssey - A Sheynem Dank! They charged me to change the world by challenging injustice and standing with those who are standing alone. I hope they would have been proud of my work. To Efrat Saraf Lavi who endured the last 10 years of this odyssey by being there for me every day - Toda Raba! 


\section{ACKNOWLEDGMENTS}

I want to thank Benjamin Baez and Kenneth Lipartito who shepherded my crooked path to finishing what should have been finished so many years ago. Norma Goonen, Daniel Saunders, Linda Bliss, and the faculty of the Departments of Education and History at Florida International University that brought their disciplines alive while always inching me forward. And thanks to Jeffrey Demsky, my Landsman from Long Island, who kept me on task and always said what had to be said.

To my Miami Dade College-Homestead Campus family: Jeanne Jacobs, my boss and friend; faculty; staff; administrators; and the library staff, a heartfelt thanks for being by my side for 15 years. I would like to especially thank Magdalena Lamarre, Meghan Clovis, Jeffery Miranda, Simeon Richardson, and Jairo Ledesma for being the sisters and brothers I did not know I had, and for their comments throughout the writing of this

dissertation. Together, the Homestead Campus' support and inspiration kept hope alive as they never wavered in the knowledge that I would complete my dissertation.

Finally, Dr. Deborah Sills (z"l), professor of Religious Studies, University of California Santa Barbara, who left us many years ago. She once reached out to an older, undergraduate who was struggling both academically and personally by simply telling him to "do history." It was an intervention that started me on an amazing journey. Thank you, Dr. Sills, as you proved that interventions do save the world one student at a time! 


\title{
ABSTRACT OF THE DISSERTATION
}

\section{HOW DOES THE WORK OF THE NEGRO YOUTH STUDY (1937-1941) FIT INTO}

\section{THE HISTORY OF THE SOCIAL SCIENCES?}

\author{
by
}

\author{
Randall Haines Kaufman
}

Florida International University, 2019

\author{
Miami, Florida
}

Professor Benjamin Baez, Major Professor

Through a historical analysis ${ }^{1}$ this dissertation addresses how the work of the Negro $^{2}$ Youth Study (NYS) fits into the historical development of sociology during the early Civil Rights Movement (CRM). Secondarily, the dissertation addresses the silence surrounding NYS and its place in Black Sociology.

As the Depression deepened, educators worried about another lost generation of young Americans. ${ }^{3}$ In response, The American Youth Commission in 1935, followed by

\footnotetext{
${ }^{1}$ N.K. Denzin and Y.S. Lincoln (Eds.), "Introduction: The Discipline and Practice of Qualitative Research" in 2005 The SAGE Handbook of Qualitative Research ( ${ }^{\text {rd }}$ ed.), SAGE: Thousand Oaks, CA, p. 1-4.

Yevhen Baranchenko, et al., "A Case Study of Inward Erasmus Student Mobility in Ukraine: Changing the Nature from Intrinsic to Instrumental.” European Conference on Research Methodology for Business and Management Studies, Academic Conferences International Limited, June 2014, 38.

${ }^{2}$ For purposes of this dissertation, the words "Negro," "Colored," and "Black" shall be used for selfidentified proper names and titles associated with studies, programs, and initiatives undertaken in the period under investigation. The terms were, in their respective historical periods, the primary or secondarily acceptable terms for African Americans. During the preparation of this dissertation, a debate has onceagain arisen, in the African American community, with respect to the use of the term "Black." The debates concerning "Negro" versus "Colored," "Black' versus "Afro American," and "Afro American" versus "African American" have a 100-year history and suggest that each generation has and will continue to describe themselves.

${ }^{3}$ Edmund De Augustine Brunner, Working with Rural Youth: Prepared for The American Youth Commission, American Council on Education, Washington, D.C., (1942), 1.
} 
the NYS in 1937, sought solutions. In particular, the NYS represents a moment in social sciences, started in the nineteenth century, or a moment when social sciences become a tool in the CRM.

Little known, the efforts of the NYS demonstrated the damage to personality that segregation and racism caused to African American children. This archival investigation offers the methods of the NYS to address issues such as, retention, family outreach, diversity, and working with African American students. While the NYS was a comprehensive investigation on the psychological and societal damage caused by racism, the study effectively cataloged African Americans' efforts to gain educational access. Before Brown v. Board of Education (1954), the NYS demonstrated the potential effectiveness of sociology as a weapon in the CRM.

Ultimately, a direct link to the Supreme Court's 1954 Brown decision could not be established. The lack of scholarly comments in the literature was real but masked by higher organization structures within the parent organization of the NYS. The NYS, as part of the history of Black Sociology, is apparent and consistent with the ideas of W.E.B. Du Bois. The ability of the NYS to demonstrate, before the Clark Doll Experiments, that young children are well aware of racial differences, not only prefigured Clarks' work but demonstrates the growing efforts to show the debilitating effects of racial segregation with evidence from the social sciences.

For educators and for society struggling to end racism and insure equitable and quality education to all children, the results of the NYS from 1941 suggest that these issues are deeply rooted in America and fundamentally need to be addressed at the level of each individual child. 
TABLE OF CONTENTS

CHAPTER

PAGE

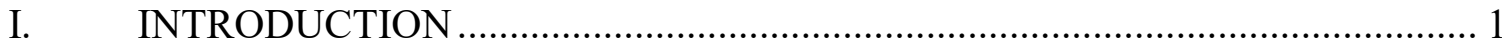

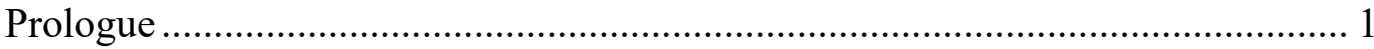

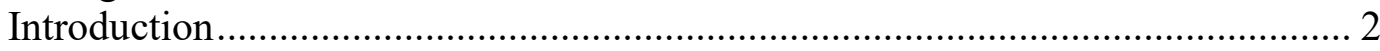

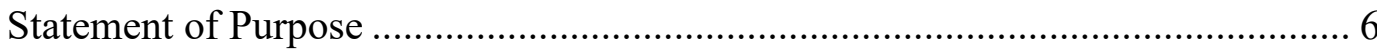

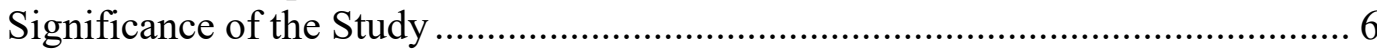

Research Question .................................................................................... 7

Research Design......................................................................................... 7

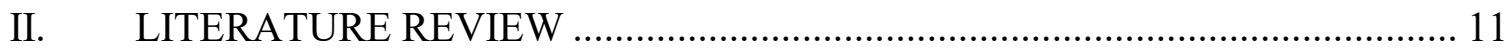

African American Education .................................................................... 13

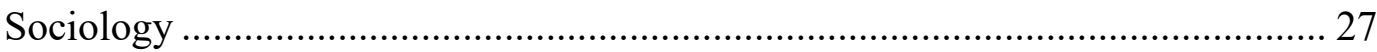

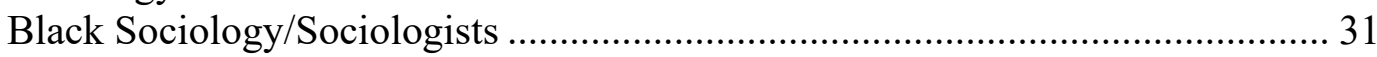

History of Social Psychology ............................................................................ 32

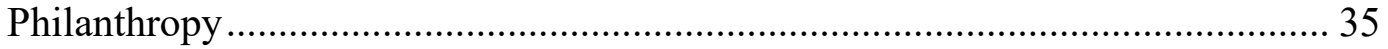

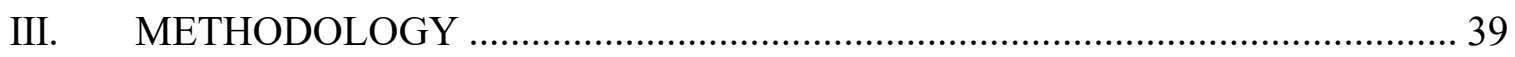

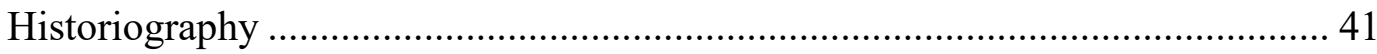

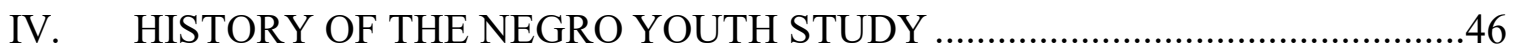

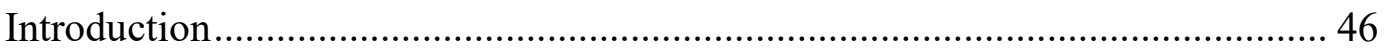

The Great Depression and Rising Social Concerns for American Youth

Youth Disenfranchisement........................................................................... 51

Analyzing the Origins, Ambitions, and Outcomes of the Negro

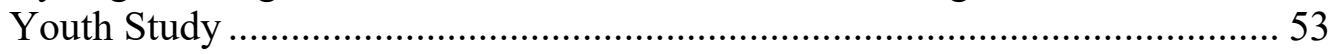

A Defining Moment: Assessing W.E.B. Du Bois' Relationship to

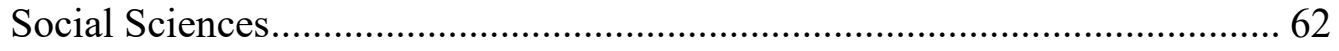

Rockefeller's General Education Board: Resurrecting Traditions of

American Progressivism in the Postwar World ............................................... 65

Promoting New Agendas and Methods: Gunnar Myrdal and the

Social Sciences of the Late 1930s and Early 1940s................................................. 67

First Traces of the Negro Youth Study ............................................................... 71

To What Noble End Do We Work? Growing Concerns about the Negro

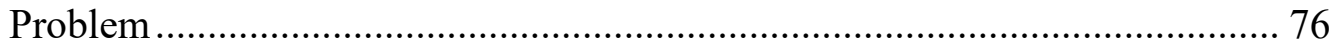

Asking Questions is the First Step to Finding Solutions: The

Negro Youth Study Begins ................................................................. 78

Codifying the Message: President Franklin Roosevelt's Support for Ending Social Inequalities................................................................ 79

Transitioning Efforts from Rhetoric to Reality: Negro Youth

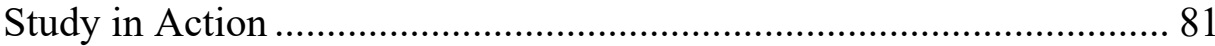

Surveying the Fruits of the Harvest: The Negro Youth Study

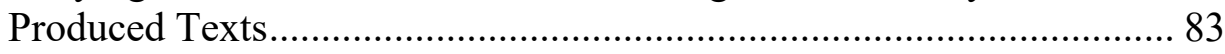


Recognizing Results: How to Situate Documents Produced by the Negro Youth Study

Settling Upon Answers: Considering the Contributions of the

Negro Youth Study

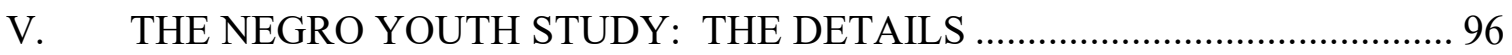

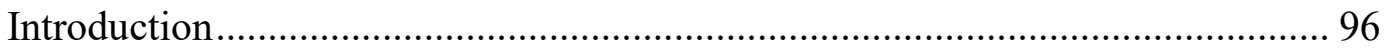

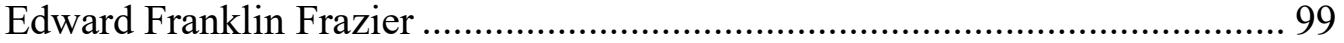

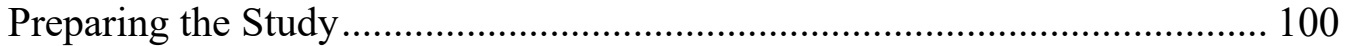

Academic Review and Discussions ........................................................... 103

Manuscript Preparation ......................................................................... 105

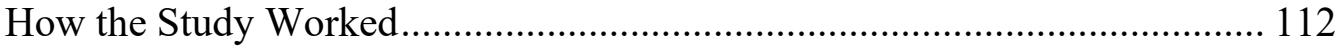

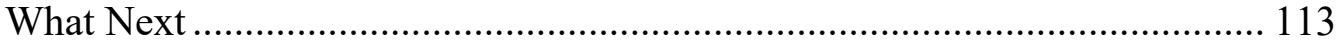

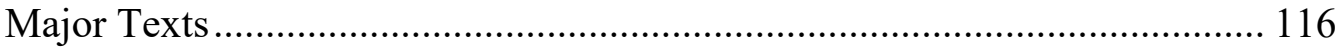

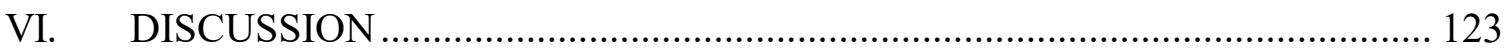

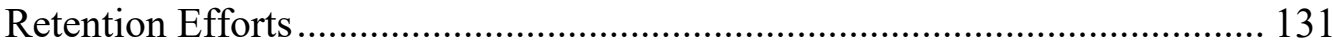

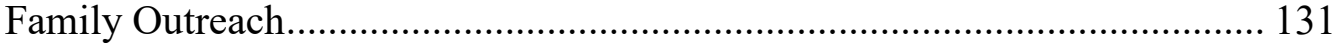

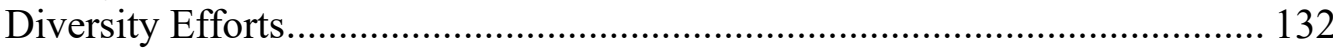

Obstacles Faced by African American Students......................................... 132

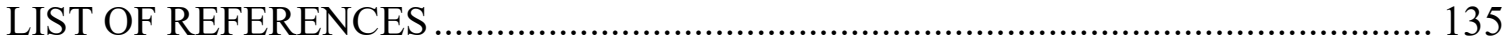

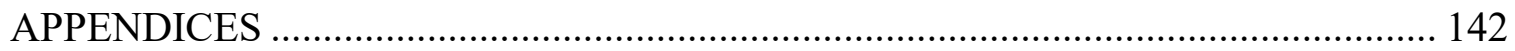

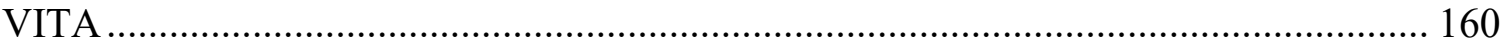




\section{ABBREVIATIONS AND ANACRONYMS}

ACE American Council on Education

AERA American Educational Research Association

AYC American Youth Commission

CCC Civilian Conservation Corps

CRM Civil Rights Movement

GEB General Education Board

HBCU Historically Black Colleges and Universities

JSTOR Journal Storage

LDF Legal Defense Fund

NAACP National Association for the Advancement of Colored People

NYPD New York Police Department

NYS Negro Youth Study 


\section{CHAPTER I}

\section{INTRODUCTION}

\section{Prologue}

Returning from World War I victorious, after having serving their country, African

American soldiers again had to come to terms with the racial realities in Jim Crow

America. They expected their sacrifices were not in vain and that the nation would

reward them with racial and social equality. For some veterans, the racial realities were

somewhat less odious in the 1920s in a decade that became synonymous with the Harlem

Renaissance, ${ }^{4}$ the New Negro, ${ }^{5}$ and Racial Uplift. ${ }^{6}$ Though a great a moment for African

American success, it was short-lived and the promises of a new world, following the

\footnotetext{
${ }^{4}$ The Great Migration sent to Harlem some of the greatest minds and brightest talents of the day, an astonishing array of African American artists and scholars. Between the end of World War I and the mid-1930s, they produced one of the most significant eras of cultural expression in the nation's history-The Harlem Renaissance. Alain Locke, became known as the "dean" of the Renaissance, describing it as a "spiritual coming of age" in which African Americans transformed "social disillusionment to race pride."
}

The Harlem Renaissance encompassed poetry and prose, painting and sculpture, jazz, swing, opera and dance. What united these diverse art forms was their realist's presentation of what it means to be African American in America, what writer Langston Hughes called an "expression of our individual dark-skinned selves," as well as a new militancy in asserting their civil and political rights. (National Museum of African American History, "A New African American Identity: The Harlem Renaissance, https://nmaahc.si.edu/blog-post/new-african-american-identit-harlem-renaissance, 2-3).

${ }^{5}$ The term "The New Negro," was coined by Alain Locke (1856-1954). In 1925, Locke edited a special edition of the magazine, Survey Graphic, devoted exclusively to the life of Harlem. He later expanded it into the anthology, The New Negro. That anthology became the manifesto of the Harlem Renaissance, or as some critics prefer to call it, the New Negro Movement. In The New Negro, Locke captures the hope and optimism of a people who have discovered "a new vision of opportunity." (National Humanities Center Resource Toolbox: The Making of African American Identity: Vol. III, 1917-1968, 1-2).

${ }^{6}$ The belief that educated, elite African American have a duty and responsibility for the welfare of African Americans remains major framework among African Americans for understanding the challenges facing them. The persistence of racial stereotypes and prejudice reinforces the perception among many African Americans that racist attitudes must be countered by positive images and exemplary behavior by African Americans (Kevin K. Gaines, "Racial Uplift Ideology in the Era of "the Negro Problem," in Freedom's Story: Teaching African American Literature and History, Washington, D.C.: National Humanities Center, 2019), 1. 
horrors and sacrifices of WWI and built on the older promises of Reconstruction, were not fulfilled. A fire was kindled in African Americans that it was time to be allowed finally to become full citizens of the United States. For African Americans, the hoped-for changes in America ended when the stock market crashed in 1929, and it became clear that the lights were quickly going out across America. By almost every measure, African Americans would suffer the greatest hardships of any group, and their handicaps were made heavier by their minority status.

\section{Introduction}

"We cannot always build a future for our youth, but we can always build our youth for the future." - Franklin D. Roosevelt ${ }^{7}$

From its beginnings in the late nineteenth century, sociology would shift from a focus on victims of social change to a focus on understanding the processes affecting society and race. ${ }^{8}$ With the Brown v. Board of Education ${ }^{9}$ decision of 1954, the social sciences, and more specifically, sociology became an established component of the Civil Rights Movement (CRM). ${ }^{10}$ The present dissertation focuses on how the Negro Youth Study (NYS) and the changing role of the social sciences, particularly sociology, situate in the CRM. ${ }^{11}$

\footnotetext{
${ }^{7}$ Address at the University of Pennsylvania, September 20, 1940. Box 54, Franklin D. Roosevelt, Master Speech File, 1898-1945. Retrieved, 17 October 2019, http://www.fdrlibrary.marist.edu/archives/collections/franklin/?p=collections/findingaid\&id=582\&rootcont entid=246681\&q=u+of+pennsylvania\#id248079.

${ }^{8}$ Jack David Eller, Social Science and Historical Perspective: Society, Science, and Ways of Knowing (New York: Routledge, 2017), 17; Gina Philogène, Racial Identity in Context: The Legacy of Kenneth B. Clark (Washington, DC: American Psychological Association, 2014), 3-4.

${ }^{9}$ Brown v. Education, 347 U.S. 483, 494 (1954).

${ }^{10}$ Philogène, $4-5$.
} 
As sociology matured from its pre-WWI roots in Antebellum racism and eugenics, the American Council on Education (ACE) ${ }^{12}$ organized the NYS in 1937. The four-year NYS represents one of the most extensive sociological studies on the personality development and social conditions of African American children, involving multiple projects reaching across the United States, resulting in four books chronicling and cataloging the work of a large number of researchers and their staff. In 1937, the NYS was the largest study conducted by the ACE in its history, generating over fifty thousand documents housed in several university archives. The inclusion of African American scholars such as Edward. Franklin Frazier, Charles Johnson, and Ralph Bunche rivaled the concurrent work of Gunnar Myrdal and his An American Dilemma: The Negro Problem and Modern Democracy (1944). ${ }^{13}$ Myrdal's work was broad in scope and

\footnotetext{
${ }^{11}$ Mary O. Furner, Advocacy and Objectivity: A Crisis in the Professionalism of American Social Sciences 1865-1905 (Lexington, KY: University of Press of Kentucky, 1975), 2.
}

\begin{abstract}
${ }^{12}$ Since its founding, ACE has played a major role in shaping K-12 and higher education in the United States. ACE advocated programs, advocated for legislation and undertook initiatives that have formed the postsecondary landscape in the United States over the past century. The Council has been an advocate for the importance of diverse campuses and expanding the higher education leadership pipeline to underrepresented groups while easing the pathways to a degree for post-traditional students, minorities, women, and members of the military and veterans.
\end{abstract}

ACE has been at the forefront of the fight for educational equity and access. This began as early as 1938 when ACE started investigating the effects of racism on African American children, worried by multiple reports multiple reports on equal opportunity in education. ("Our History: A History of Leading the Way," American Council on Education, https://www.acenet.edu/About/Pages/history.aspx).

${ }^{13}$ In 1944 Gunnar Myrdal, a Swedish economist, published his massive study of black-White relations. A huge collaborative effort, sponsored and financed by the Carnegie Corporation, Myrdal's book became an instant classic. No mere book, it constituted a historic event. Helen and Robert S. Lynd, the noted coauthors of Middletown, called Myrdal study "the most penetrating and important book on contemporary American civilization that has ever been written."

Although Myrdal's book contained more than 1500 pages filled with vast amounts of data and numerous hypotheses, one simple, pervasive theme unified the huge tome. Myrdal asserted that White Americans experience a troubling dilemma because of a discrepancy between the hallowed "American Creed," whereby they think, talk, and act under the influence of egalitarian and Christian precepts, and the 
massive in content and the NYS also had national coverage but focused exclusively on the damage racial segregation had on African American children. The NYS was conducted at a time of tremendous change and became a pivotal player in the history of sociology and part of what would come to be called "black sociology."

During the early years of the black sociology, African American sociologists were on separate trajectories in race research from their White colleagues, beginning with William Edward Burghardt Bois and his work at the Atlanta Sociological Laboratory/Conference Series. ${ }^{14}$ For sixteen years, Du Bois laid down some of the foundations of American sociology while creating black sociology, ${ }^{15}$ and ensured that the study of race and racism was a part of sociology's core. ${ }^{16}$ His work on race, extended by other scholars, created an academic discipline that has become not only a foundation of the social sciences, but also educational research and the CRM. ${ }^{17}$ The power of that work would be manifested in 1954 .

In 1954, the National Association for the Advancement of Colored People's (NAACP) Legal Defense and Educational Fund (LDF) was continuing a recently

\footnotetext{
oppressive way they treated African Americans. Myrdal predicted that this moral dilemma, heightened by the democratic rhetoric of World War II and certain other social trends, would soon force "fundamental change in American Race relations" and end America's greatest scandal (David W. Southern, Gunnar Myrdal and Black-White Relations: The Use and Abuse off An American Dilemma, 1944-1969 (Baton Rouge, Louisiana: Louisiana State University Press, 1994, xiii).

${ }^{14}$ Eller, 171.

${ }^{15}$ Earl Wright, II and Thomas C. Calhoun, "Jim Crown Sociology: Toward an Understanding of the Origin and Principles of Black Sociology via the Atlanta Sociological Laboratory," Sociological Focus 39, no. 1, (2006): 5-6.

${ }^{16}$ Wright and Calhoun, 7.

${ }^{17}$ See pages 62-78 in Aldon D. Morris, The Scholar Denied: WEB Du Bois and the Birth of Modern Sociology (2015) for the work of Monroe Work, Richard R. Wright Jr., and George Edmund Haynes.
} 
developed strategy in its battle against racial segregation. The strategy was to challenge segregation in public schools using social science research in the courts up to and including the Supreme Court. The research, anchored in sociology, arrived at the Supreme Court in Brown, reflecting almost sixty years of sociological research on racism. ${ }^{18}$ Ironically, sociology had just, twenty-five years before, been anchored in the Antebellum racial status quo and Eugenics. Howard Winant wrote that at the turn of the twentieth century, sociology was immersed in fears of "Race-war," migration, fertility, breeding, and human genetics. ${ }^{19}$ James McKee highlighted scholarly articles in the American Journal of Sociology, where researchers were writing on "civilization and savagery" and "advanced and backward races." McKee saw many sociologists as believing those of African origins were descended from a "savage culture."20

Although little remembered, the NYS also played an essential role in establishing debates in contemporary educational research studies. Carla Monroe's study of “colorizing" educational research intersects with this legacy, as does Linda Tillman's work on developing culturally-sensitive research approaches. Given the scale of the NYS, its use of sociology to highlight the way race manifested itself in the United States, and its explicit attempt to shape social policy, a history of this forgotten project is necessary to better understand the role of social sciences in the CRM.

\footnotetext{
${ }^{18}$ John Phillip Jackson Jr., “The Transformation of Social Science into 'Modern Authority' in Brown v. Board of Education, 1945-1957” (Ph.D. dissertation, University of Minnesota, 1996), 1.

${ }^{19}$ Howard Winant, "The Dark Side of the Force: One Hundred Years of the Sociology of Race," in Sociology in America: A History, ed. Craig C. Calhoun (Chicago: University of Chicago Press, 2007), p.536.

${ }^{20}$ James McKee, Sociology and the Race Problem: The Failure of a Perspective (Urbana: University of Illinois Press, 1993), 29.
} 


\section{Statement of Purpose}

The present dissertation, I used historical research and methods to recover a story about the NYS illustrates its key—-though now forgotten-role in shaping the social sciences' impact on the history of race and the CRM in the United States. African American scholars, namely Edward Franklin Frazier and Charles S. Johnson, key researchers in the NYS, who played an earlier an important role in establishing the quantitative foundations for public school integration than the literature credits. Also, within the history of the social sciences, the little-remembered NYS also played an essential role in the development of black sociology. Working with the literature of the social sciences confirmed the role that sociology, especially black sociology, occupied during the early and mid-twentieth century, setting the ground for current scholars like Michael Eric Dyson. ${ }^{21}$ The present dissertations contribution to the fields of history and education it elevating silent account of the NYS. The data that I researched, analyzed, and present here are archival but also sociological, geared toward fostering deeper understandings within the dominant White community of African Americans' social challenges.

\section{Significance of the Study}

My study suggested that understand the historical place of what should have been a major study in the CRM, which used the social sciences to promote racial equity. The NYS may, however, represent further an important inflection point where social science research became a major tool in the fight to promote American social justice. For

\footnotetext{
${ }^{21}$ Richard Robins, "Charles S. Johnson," in Black Sociologists: Historical and Contemporary Perspectives, eds. James E. Blackwell and Morris Janowitz (Chicago: University of Chicago Press, 1974), 70.
} 
example, Daniel Patrick Moynihan, who wrote the influential The Negro Family: The Case For National Action (1965), marshaled his statistics from Frazier's NYS research.

The NYS was a prolonged study of racial dynamics in the United States, providing a unique snapshot of how sociological insights helped propose effective remedies to racial inequities in education. It serves as an example of how sociology became a major part of the CRM. Today, the role of sociology in addressing racial problems and in policy recommendations is unquestioned. The absence of the NYS in our histories of race is, therefore, essential to understand. This research also has direct significance to several pressing issues in higher education today.

\section{Research Question}

My study focused primarily on how the Negro Youth Study reflects a changing sociology in relation to the study of race. I also sought to understand why such a largescale study as the NYS continues to receive little scholarly attention. The primary question in this histography, therefore, was: How does the Negro Youth Study fit into the historical development of the social sciences during the early civil rights movement? The secondary question for which this historiography sought an answer is: Why has there been a historical silence in relation to the Negro Youth Study and its place in the black sociology which emerged at that time?

\section{Research Design}

I conducted a historiography drawing together primary sources from various archives mostly housed at universities. The most important primary source was, of course, the NYS itself. I reviewed all reports associated with the study and analyzed scholarly reviews of secondary sources from the research literature, as well as newspaper 
articles published in major African American and White newspapers. Primary sorting of documents consisted of electronic and physical, hand searches using the following overarching terms:

- "Negro Youth Studies"

- "Youth Studies"

- "American Youth Commission"

- "American Council on Education"

- "Negro Education"

- "Race Relations"

Secondly, I focused on individual documents concerning the NYS.

My decision to apply historical methods to a study focused on educational developments reflects its inherent breadth. Historians claim interpretative license to survey broad periods and sources in search of patterns of causality and result. While this subjectivity may produce unease, the same flexibility also has positive effects as it encourages original research and interpretations. ${ }^{22}$ Assimilating new research, read through a contemporary lens and filtered through sociological literature, my study addresses gaps of knowledge about the NYS and CRM.

In history, a primary source refers mostly to archival material. The foundation of this current dissertation is necessarily archive-based as the historical actors, NYS test subjects, and contemporary observers are no longer with us. The archival material provided the rationale, objectives, and results of the NYS while laying the basis for assessing its success within the historical trajectory of sociology and the CRM. ${ }^{23} \mathrm{I}$ reviewed the following archives

\footnotetext{
${ }^{22}$ John. L. Rury, "Historical Research in Education," in Judith Greene, ed. Handbook of Contemporary Methods in Education Research (Abingdon, UK: Routledge, 2006), 323.

${ }^{23}$ Rury, 325.
} 
- American Council of Education/Negro Youth Studies (Hoover Archives at Stanford University)

- E. Franklin Frazier Papers (Howard University Archives)

- Charles Johnson Papers (Fisk University Archives)

- General Education Board (Rockefeller Archives)

Because I argue the NYS reflects a key moment in the development of sociology's current role in race relations and policy, secondary sources were necessary. The books and journals already referenced in this dissertation provided a start. Additionally, the reactions, responses, and opinions of African American and White communities ultimately determined the place, value, and influence of the NYS. Thus, newspapers and magazines - both White and African American outlets-were pivotal in interpreting, disseminating, and evaluating the work of the NYS and of the social sciences more generally. ${ }^{24}$

In this historical review, the background history and historical context of the dissertation covers long periods in broad strokes. Those strokes seemingly left large gaps in the historiography and timeline. However, the nature of the activities in the development of sociology, psychology, and CRM were not continuous or contiguous. The apparent flurry of activities interspersed with periods of silence reflect the reality of the various professional disciplines and private efforts in civil rights not operating in a unified effort and often unaware of the actions of others.

To place the NYS in its historical location, historiography served as a means to assess the evidence secured from primary and secondary sources. Because historians must offer explanations that are mainly their own, individual interpretive frameworks

\footnotetext{
${ }^{24}$ Rury, 324.
} 
invariably frame the inquiry process with evidence usually dictating limits of interpretive license. ${ }^{25}$ To frame the scholarly arguments around the research questions, an understanding of the literature and scholarly interpretations and debates is necessary. As this discussion spans both education and history, the literature review encompasses an element of breadth where a dissertation typically requires a narrower focus. Ranging from sociology to social psychology to philanthropy, in chapter two I explore both disciplines while acknowledging the discovery of materials not well known to scholars and the general public. The general literature surrounding the NYS and its parent organization, the American Council on Education, are well known and frame the literature review. It is within this framework that I address the research questions, and the archival material may be better understood.

${ }^{25}$ Rury, 327. 


\section{CHAPTER II}

\section{LITERATURE REVIEW}

The actions, results, and historical placement of the NYS can be understood as an implementation of a series of nation-wide community studies grounded in the practical application of sociology and social psychology. As the work of the NYS represents the application of various academic disciplines beyond sociology and social psychology, a literature review of the NYS must also bring into discussion the intersection of secondary disciplines, including the history of African American education, philanthropy, and historiography.

There has been one published dissertation and one master's thesis containing secondary interests in the NYS. In searching the dailies of the historical period under study, I located four New York Times articles. Journal articles, while offering slightly better coverage, do not suggest the work of the NYS has generated great interest among educators, academics, or the general public. Of greater interest to historians have been the Depression itself and the two events framing the work of the NYS, the Harlem Renaissance and the Brown decision. The lack of interest becomes obvious in a gross survey of the three specific phrase searches ("American Council on Education," "American Youth Commission," and "Negro Youth Study") from ten databases reflecting both the academic and general reading literature with no time constraint. The NYS was in six published works, the AYC in over six hundred works, and the ACE in over thirty thousand (see Appendix A). Similar results occurred among African American newspapers, with four articles for the NYS, sixty for the AYC, and the ACE with over $425 .{ }^{26}$ 
At first glance, the NYS appears almost completely hidden in the White and African American literature. However, there is overlap between the citing of the work of the NYS and the AYC. Some of the most important work of the NYS has been cited frequently as having come from the AYC. Though the AYC represents the higher/parental organizational structure for the NYS, the lack of direct citing of the NYS as the source of its own work illustrates the documented historical silence of the NYS.

An example of this historical silence is Earl Richard Moses's 1948 dissertation on the "Migrant Negro Youth: A Study of Culture Conflicts and Patterns of Accommodation Among Negro Youth." In the bibliography, there were ten works listed under "Studies of Negro Youth" created by scholars working in the NYS ${ }^{27}$ Moses listed all ten as AYS publications. Moses's dissertation was finished just five years after the NYS concluded, but Moses did not cite the NYS. Almost every citation, both in the mass media and academic literature, has cited the AYS, the parent organization, in place of the NYS. African American newspapers at the time similarly cited the AYS in their reporting of the work of the NYS in the form of biographies of local African Americans. One outlier in this respect was a congratulatory article in the newspaper The Kansas American in 1941, which acknowledged and delineated the completion and works of the NYS. ${ }^{28}$

\footnotetext{
${ }^{26}$ Electronic searches were performed July 25, 2018 in PsycINFO (1806-2011), PubMed (1946-2011); and Web of Science (Science Citation Index Expanded, 1899-2011; Social Sciences Citation Index, 1900-2011; Arts and Humanities Citation Index, 1975-2011).

${ }^{27}$ Earl Richard Moses, "Migrant Negro Youth: A Study of Culture Conflicts and Patterns of Accommodation Among Negro Youth" (Ph.D. dissertation, University of Pennsylvania, 1948), 269.

28 “The Negro Youth Study Completed,” Kansas American, November 14, 1941 (vol. 8, no. 1), 10.
} 
Though there is a dearth of secondary literature directly focused on the NYS, the NYS does arise in literature on the AYC, ACE, and CRM, albeit in a limited fashion. Within this literature, the NYS is almost always subsumed under its parent organization; the AYC. As such, in this review, I illustrate the multidimensional importance of the NYS in the history of sociology during the CRM. I demonstrate how, historically, the roles of sociology, psychology, and philanthropy have intertwined with the actions, results, and purpose of the NYS, as well as its place in the CRM. The literature may be minimal; however, its review helps to understand the context while offering scholarly opinions of the world in which the NYS operated.

\section{African American Education}

In a great many instances, the school buildings now in use of the colored children are in a poor state of repair. Generally, many are poorly lighted and heated, and in many instances are too small to give adequate accommodations to pupils. Very few rural colored schools are equipped with modern single desks. Little or no provision is made for teaching health and sanitation. ${ }^{29}$

By the end of the nineteenth century, state constitutions had mandated legal segregation, among other marginalization laws making clear that White and African American children would have separate social and educational experiences. In 1875, the

Alabama Constitution ensured as such:

Article XIII Section 1. The general assembly shall establish, organize, and maintain a system of public schools throughout the state, for the equal benefit of the children thereof between the ages of seven and twenty-one years; but separate schools shall be provided for the children of citizens of African descent. ${ }^{30}$

\footnotetext{
${ }^{29}$ Vanessa Siddle Walker, Their Highest Potential: An African American School Community in the Segregated South (Chapel Hill: The University of North Carolina Press, 1996), 2.

${ }^{30}$ Sharon Gay Pierson, Laboratory of Learning: HBCU Laboratory Schools and Alabama State College Lab High in the Era of Jim Crow (New York: Peter Lang Publishing, 2014), 17.
} 
By 1905, local and state legislators across the South had emasculated the fourteenth and fifteenth amendments, and "the great rollback of Black reconstruction took place." 31 The South grudgingly accepted that a system of education that emphasized manual labor and practical skill should enable Whites to position African Americans as an economic asset to exploit while controlling this workforce. ${ }^{32}$

Despite de jure segregation and the latter setback of Plessy v. Ferguson, ${ }^{33}$ Reconstruction, and Jim Crow legal decisions, by 1883, Pierson suggested African Americans were pressing ahead and actively seeking to educate themselves. The result was the creation of common schools in every county of every Southern state. Successes began as early as Emancipation, as African Americans carefully collaborated with White educational leaders and philanthropic organizations, making great strides and growing from thirty-two African American colleges and universities in the South by 1890 to a total of forty-one by 1913. Pierson noted most were "colleges and universities in name only."34 In demonstrating the social pressures facing African American schools, Pierson produced the 1916 report, The Social Studies in Secondary Education: A Six-Year Program Adapted Both to the 6-3-3 and 8-4 Plans of Organization and Report of the Committee on Social Studies of the Commission on the Reorganization of Secondary Education of the National Education Association (1916), commonly known as the Jesse Jones Report. ${ }^{35}$

\footnotetext{
${ }^{31}$ Pierson, $17-18$.

${ }^{32}$ Pierson, 19.

${ }^{33}$ Plessy v. Ferguson, 163, U.S. 537 (1896).

${ }^{34}$ Pierson
} 
The Jones Report, conducted for the U.S. Bureau of Education, offered one of the first significant statistical analyses on African American education that prefigured the NYS. While collecting a tremendous amount of statistical data, the report reflected the programs of Booker T. Washington and his views on industrial education. The Jones Report identified twenty-three Southern cities with a population of twenty thousand or more had not one African American public high school. This meant forty-eight thousand African American students in the Southern states had no access to public high school. The Jones Report was widely accepted by segregationists and Whites who favored industrial education for African Americans. Pierson's work documented the disparity in spending for public schools, facilities, and quality of the teachers in public African American schools. ${ }^{36}$

Response to the Jones Report was swift and mixed within African American academic ranks. Charles Johnson, Sociology Chairman at Fisk University, affirmed Jones's substantial contributions, noting the double cultural standard in both education and social life while highlighting the way to new dreams was through "the bitter remnants of a sluggish past." ${ }^{, 37}$ At Howard University, D.O.W. Holmes, a professor of education who later became the dean of the College of Education, also praised Jones, acknowledging the fraud the report exposed. Contrasting the seemingly positive praise

\footnotetext{
35 "The Social Studies in Secondary Education: A Six-Year Program Adapted Both to the 6-3-3 and 8-4 Plans of Organization and Report of thee Committee on Social Studies of the Commission on the Reorganization of Secondary Education of the National Education Association," National Council for the Social Studies (Washington, D. C.: Office of Educational Research and Improvement, 1916).

${ }^{36}$ Pierson, 21-22.

${ }^{37}$ Pierson, 26.
} 
for the Jones report, Carter G. Woodson, noted historian and founder of The Journal of Negro History (1916), had nothing positive to say and found the Jones Report narrow minded, short sighted, and undermining of African American efforts in the fight against racial injustice. ${ }^{38}$

The Jones report was reprinted in 1969 by the Negro Universities Press, an important publisher of historical documents concerning the history of the CRM. ${ }^{39}$ Like the NYS, the Jones Report contained a wealth of demographic, statistical, and census data understood in light of the criticisms of the same data. The Jones report opened with a "letter of transmittal" by the Secretary of the Department of the Interior, Bureau of Education. Secretary Philander Priestly Claxton quoted a statement sent by the University Commission on the Southern Race Questions representing state universities of eleven Southern states, expressing his belief in the problem of racial segregation in education:

The South cannot realize its destiny if one-third of her population is underdeveloped and insufficient. For our common welfare, we must strive to cure disease wherever we find it, strengthen whatever is weak, and develop all that is undeveloped. The inadequate provision for the education of the Negro is more than injustice to him; it is an injury to the White man. ${ }^{40}$

The Jones Report was immersed in the period when the United States acquired colonies in the Spanish-American War. The question of race in the report, seen as "encircling the world at this time," ${ }^{41}$ saw the American population as entering more and

\footnotetext{
${ }^{38}$ Pierson, 26-27.

${ }^{39}$ Department of the Interior: Bureau of Education, "Negro Education: A Study of the Private and Higher Schools for Colored People in the United States, New York: Negro Universities Press, 1969, p. ix.

${ }^{40}$ Department of the Interior, Bureau of Education, "Negro Education," p. ix-x.

${ }^{41}$ Jones Report, 1.
} 
more into problems of race and nation. For the sociologists, the conditions for African

Americans was clear:

The opportunity to serve so clear, the responsibility to assist so certain, and the necessity of solution so absolute as in the case of the black people who in field and shop and home are in daily contact with White people. How is American democracy to meet this test of its wisdom and idealism? ${ }^{42}$

While the Jones Report carefully treaded some of the political realities of the period, namely racism and Eugenics, it did not hold back on the inadequacies of facilities and teachers in African American schools:

Inadequacy is the outstanding characteristics of every type and grade of education for Negroes in the United States. Though the facilities for all types and grades of education are strikingly inadequate, a large number of colored leaders have been much more eager for the literary and collegiate type of school than for teacher-training, agricultural, or industrial instructions. ${ }^{43}$

The Jones Report's scathing data on the economic situation of African Americans aligned with the earlier work of Du Bois and his efforts with the NAACP as the editor of Crisis. ${ }^{44}$ Patricia Sullivan saw the NAACP's work on segregation beginning concurrently with its fight against lynching. As the NAACP's media arm, Crisis immediately became an important component of the CRM. In the first issue in 1910, Du Bois argued the trend toward separate schools in the North undermined a primary purpose of public education: to advance human contact, acquaintanceship, and sympathy, while obstructing African American advancement. It was "an argument against democracy and an attempt to shift

\footnotetext{
${ }^{42}$ Jones Report, 1-2.

${ }^{43}$ Jones Report, 9.

${ }^{44}$ Alvis V. Adair, Desegregation: The Illusion of Black Progress (New York: University Press of America, 1984), 36-38.
} 
public responsibility from the shoulders of the public" to African Americans and their children. ${ }^{45}$

While various academic and social action groups mobilized to ameliorate the conditions of the children of the Great Depression, African American children drew the focus of the ACE and a major share of the philanthropic world. The quotations from the Jones Report illustrate the typical conditions for African American children in the South and approximated the conditions of African American schools in the North. The focus of this dissertation is how the work of the NYS as an arm of the ACE, formed in 1935 which immediately address concerns toward African American youth.

As one of the nation's oldest professional organizations representing $\mathrm{K}-12$ and higher education, ACE continues to play a major role in policy and advocacy for both K12 and Higher Education. The members of the commission were professional educators, $\mathrm{K}-12$ teachers and administrators, and researchers from universities and Historically Black Colleges and Universities (HBCU). In all of their work and research, the ACE focused on students and particularly $\mathrm{K}-12$ students. As the ACE provided the foundation for the AYC and NYS, the best filter for this research is to utilize the lens of the history of education. In particular, there is a need for a more in-depth investigation into the education of African American youth.

The history of education is not a single homogeneous category; it consists of multiple histories. ${ }^{46}$ Until 1925 , the history of education was a frequent professional

\footnotetext{
${ }^{45}$ Patricia Sullivan, "Prelude to Brown: Education and the Struggle for Racial Justice During the NAACP's Formative Decades, 1909-1934," in from the Grassroots to the Supreme Court: Brown v Board of Education and American Democracy, ed. Peter F. Lau (Durham, NC: Duke University Press, 2004), 166167.
} 
offering in teacher education. Later, primacy was placed on the social foundations of education in teacher training that spread from Columbia's Teachers College across the nation. This shift manifested in the creation of the professional formation of the history of education via the Education Society and History of Education Journal, which became the History of Education Quarterly. Despite this professional growth in the history of education, the significance of the field declined. In 1958, a Ford Foundation committee of scholars declared the history of education had been "shamefully neglected by American historians. ${ }^{\circ 7}$

The downward spiral of the history of education was exacerbated by the increasing role and significance of science and scientific research in the field of education. The main field of inquiry was the mental measurement movement, particularly intelligence and achievement testing. Another factor was the emphasis placed on child development in education. The downward spiral in the history of education led to the idea that the most valuable and relevant training for teachers would be determined scientifically in fields such as psychology. In the early twentieth century, science became a panacea.

This downward pressure from within the larger professional education discipline against the history of education was heavily influenced by prominent academics such as James Conant, who suggested the courses "frequently attempt[ed] to patch together

\footnotetext{
${ }^{46}$ Gary McCulloch, The Struggle for the History of Education: Foundation and Futures of Education (London: Routledge, 2011), 58.

${ }^{47} \mathrm{McCulloch}, 57$.
} 
scraps of history, philosophy, political science, sociology, an ideology." ${ }^{, 4}$ Conant further called these courses "of limited value," arguing "the discipline of psychology [...] more closely related to the work of teaching than are philosophy, history, and sociology." In 1949, Archibald Anderson believed the history of education was valueless because it was theatrical, and its aims, material, and methods had failed. ${ }^{49}$ Anderson concluded "mainstream" historians and professional historical organizations, such as the American Historical Association, remained unaware of the history of education. McCulloch, citing the work of Michael Katz and his The Origins of Public Education (1976), suggested a framework to understand the history of education and its connection to social content by identifying four developmental aspects: industrialization and urbanization, the assumption of the state's responsibility for social welfare, the invention of institutionalization as a social solution to social problems, and the redefinition of family. ${ }^{50 .}$

Toward the end of the 1960s, the notion of orienting the history of education toward relevant social issues impacted the professional development of teachers. In 1967, Freeman Butts suggested a renewal in the history of education required constructing a vital and viable conceptual framework which would match the requirements of structural scholarship as well as the findings of recent social science scholarship on social change. ${ }^{51}$ In 1968, with the addition of Division F (History and Historiography of Education), the

\footnotetext{
${ }^{48}$ McCulloch, 59.

${ }^{49}$ McCulloch, 59.

${ }^{50} \mathrm{McCulloch}, 59-60$.

${ }^{51}$ McCulloch, 67.
} 
American Education Research Association (AERA), the largest professional organization for educational researchers, cemented the history of education within the discipline of education. By the 1970s and 1980s, a wave of new education historians wanted to shift toward a broader concept of the education and growth of public schools as naturally woven in the fabric of American society. These historians aimed to move educational historiography toward social and intellectual history, emphasizing the role of the development of bureaucracy in public schooling. ${ }^{52}$

Among education historians, while decrying the focus on the damage done by segregation, a small group of African American scholars looked at the academic successes that were part of segregated African American schools. Sharon Pierson offered a view from below researching Alabama State Laboratory Schools (High Schools) and their academic success during Reconstruction and on into World War I. These successes seemed more impressive as Pierson noted the almost immediate and violent opposition to African American schools by vigilante groups such as the Ku Klux Klan and local politicians..$^{53}$

While African Americans were building schools and college, Adair detailed the historic court battles that helped African Americans take down and reconstruct African American children's access to schools so they could excel academically and strive for professional degrees. The courts have been the most influential force in the course of African American education, and assaults on segregation since Emancipation generated

\footnotetext{
${ }^{52}$ McCulloch, 62.

${ }^{53}$ Pierson, 18-20.
} 
many lawsuits. ${ }^{54}$ From 1896 to 1950 , the courts predominantly extended civil rights protection by requiring African American teachers' salaries be equal to White teachers, though they failed to address the question of significantly inferior facilities for African American children. ${ }^{55}$ The literature notes "equalization" as the policy adopted to challenge segregation. Until the NAACP's Legal Defense Fund brought forward major studies and social sociology into the courtroom, African Americans went to court to demand equal facilities, teacher salaries, and support for their children in schools with little discussion on the emotional and psychological damage segregation caused their children.

In the 1930s and 1940s, much of the literature on segregation did discuss sociology, though major scholarly dialogues, debates, or conferences on segregation or race were few. The changes mandated by the Sweatt v. Painter (1950) decision, ${ }^{56}$ as Adair noted and many scholars in the decades after Brown noted, were not convinced Brown achieved its goals. However, the legal, sociological, and moral concepts used in Brown have since become widely applied by the courts to the public sector, leaving the private sector to latter cases. ${ }^{57}$ Adair, in summarizing Brown, stated:

Suffice it to say that the purely legal ramification of desegregation has been adequately addressed and contested in the courts. This conception of the legality or constitutionality of desegregation in education needs to be broadened to include the right to full participation by Blacks at all levels including management and development of curriculum content to reflect

\footnotetext{
${ }^{54}$ Adair, 27.

${ }^{55}$ Adair, 29.

${ }^{56}$ Sweatt v. Painter, 339 U.S. 629 (1950). The case was a major precursor to Brown in which an African American student was refused admission to the University of Texas Law School on the grounds that the Texas State Constitution prohibited his admission as an African American.

${ }^{57}$ Adair, 30-31.
} 
the Black cultural and aesthetic base and its general sociological and psychological dimensions. ${ }^{58}$

Sullivan, linking the work of Du Bois to the Depression, moved quickly from the early nineteenth century to September $19^{\text {th }}, 1936$, when President Franklin D. Roosevelt appointed the ACE:

Making a study of the experience under the existing program of Federal aid for vocational education, the relation of such training to general education and to prevailing economic and social conditions, and the extent of the need for an expanded program of Federal aid for vocational education. $^{59}$

In a letter dated April $19^{\text {th }}, 1937$, Roosevelt stated, after some thought to the general relationship of the federal government to education, it was his understanding that the committee had much information on the subject. He requested the committee give more extended consideration to the subject of the federal relationship to state and local conduct of education, and to prepare a report. ${ }^{60}$ In response to Roosevelt's request, the committee issued a report noting extreme differences in the educational opportunities of White and Negro children in the Southern states, specifically: number of children out of school, length of school terms, student progress through the grades, facilities for transporting pupils to schools, pupil loads of teachers, educational qualifications of teachers, salaries, and adequacy of school plants and equipment. The committee concluded public elementary and secondary schools for African American children were far less extensive and markedly inferior to those for the White population. ${ }^{61}$

\footnotetext{
${ }^{58}$ Adair, 32.

${ }^{59}$ Sullivan, 169.

${ }^{60}$ Floyd W. Reeves, Special Problem of Negro Education (Westport, CT: Negro Universities Press, 1970), iii.
} 
In the evidence reviewed in my dissertation, $\mathrm{ACE}$ was the only organization to address the situation with accreditation. Voluntary, peer-led accreditation has been a foundation of American higher education since the nineteenth century. Being "fully accredited" is life or death to an institution. Using data from the Southern Association of Colleges and Secondary Schools (SACS), the ratio of Class A ratings between White and African American public colleges was 67 to 29 percent fully accredited, respectively. Looking at accredited schools by the Association of American Universities, the difference is stark. About 16 percent of public and 14 percent of private White colleges were accredited. For the entire nation, only Fisk University was an accredited African American university before World War I. ${ }^{62}$

By the 2000s, scholars increasingly demonstrated their interest looking comparatively at racial segregation of other groups such as Native Americans, Mexican Americans, and Asian Americans. Peter F. Lau, who edited From Grassroots to the Supreme Court: Brown v. Board of Education and American Democracy (2004), included essays on the precursors to Brown and the work of minority activists in the Western United States to end school segregation. Brown and the work of the NYS did not exist in a vacuum; the case of Menendez v. Westminster $(1946)^{63}$ prefigured Brown in many ways. Ruiz, in a similar fashion, highlighted that in the West, it was primarily Asian Americans,

\footnotetext{
${ }^{61}$ Reeves, 34 .

${ }^{62}$ Reeves, 35-36.

${ }^{63}$ Mendez v. Westminster, 64 F. Supp. 544, aff'd, 161 F.2d 774 (1947). In 1947, a Federal Appeals court ruled that racial segregation was unconstitutional. This case, representing Mexican-American children in California, was a major precursor to Brown and figured prominently in the NAACP case before the Supreme Court.
} 
Mexican Americans, and Native Americans who bore the brunt of school segregation. For Native American children, many had to endure not just racial segregation but literal incarceration in Indian boarding schools.$^{64}$ Lau further presented the case of Texas, which in 1875 had state-mandated segregation. By 1880, most African American Texans were taught in "churches, barns, and other rented buildings." The Topeka Colored Citizen wrote, "we hear of no Irish schools, no German schools, no Swedish schools. No, not one." ${ }^{95}$ Citing Quintard Taylor, the battle for school integration occurred all over the West and were "the premier weapon in the campaign for both economic and racial equality."

The well-known treatment of Chinese Americans in the West was similar to the treatment of African Americans during this period. The city of San Francisco was an early adopter of non-segregated schools for all except Chinese Americans. The Passage of Political Code 1662 barred Chinese children from public schools where African Americans, American Indians, and Japanese American students attended. Through the efforts of the local community, by the time of the Depression, segregation against Chinese American children had been abandoned by the school board. ${ }^{67}$

Before World War II, the pressures against Mexican Americans were fierce and palpable in the nation. In the Saturday Evening Post, a series of articles urged the restriction of Mexican immigration. The titles speak loudly: "The Mexican Invasion," "West and Other Mexicans," and "The Alien on Relief." Between 1931 and 1934,

\footnotetext{
${ }^{64}$ Peter F. Lau, ed., From Grassroots to the Supreme Court: Brown v. Board of Education and American Democracy (Chapel Hill, NC: Duke University Press, 2004), 44-45.

${ }^{65} \mathrm{Lau}, 45$.

${ }^{66} \mathrm{Lau}, 45-46$.

${ }^{67} \mathrm{Lau}, 46-50$.
} 
approximately one-third of the Mexican population in the United States were either deported, even though the majority (estimated 60 percent) were native U.S. citizens. ${ }^{68}$

The strength of Lau's work suggests that sociological research and the results of the work of the NYS and others were taken up by the NAACP in 1951 and figured into Brown. Lau suggested that by 1959, with Virginia's NAACP leading the way for equality in schools, the equalization campaign was successful in challenging the physical inequalities of segregation, though the Virginia's NAACP had overlooked segregation's effects on the psychological and other intangible consequences. Quickly following the Supreme Court's decision against racial segregation in Sweatt v. Painter (1950), the NAACP announced it would end equalization suits and only sue on the grounds that segregated education was unconstitutional. ${ }^{69}$

In his call for the "Talented Tenth," "70 Du Bois argued African Americans must have a path to academic and intellectual education to move from the "house servant to Servant in the house":

In Education, we must seek to give colored children free public school training. We must watch with grave suspicion the attempt of those who, under the guise of vocational training would fasten ignorance and menial service on the Negro for another generation. Our children must not in large numbers, be forced into the servant class; for menial service is still, in the main, little more than an antiquated survival of impossible conditions. It has always been as statistics show, a main cause of bastardy and prostitution and despite its many marvelous exceptions, it will never come

\footnotetext{
${ }^{68}$ Lau, 58-59.

${ }^{69}$ Lau, 146-147.

${ }^{70} \mathrm{Du}$ Bois used the term "the talented tenth" to describe the likelihood of one in 10 black men becoming leaders of their race in the world through methods such as continuing their education, writing books, or becoming directly involved in social change. He strongly believed that blacks needed a classical education to be able to reach their full potential, rather than the industrial education promoted by the Atlanta Compromise endorsed by Booker T. Washington and some White philanthropists. Du Bois saw classical education as the basis for what, in the twentieth century, would be known as the role of public intellectuals.
} 
to that light of decency and honor until the house servant becomes the Servant in the house. ${ }^{71}$

In 1919, on the tenth anniversary of the founding of the NAACP, Du Bois argued: The facts must be gathered and assembled. This requires effort. Facts are not gotten out of one's imagination. Their gathering and interpretation are skilled work. Research workers of a practical experience are needed. Field investigations, in which domain the Association has already made some notable contributions, are essential to good work. More money. ${ }^{72}$

In the fight to end racial segregation, many had fought in the courts, at the ballot box, and in the academy. It was until sociology's research on race, married with the legal efforts of the NAACP, that racial segregation was proven as having an insidious effect on children, and that 'separate but equal' was be considered unconstitutional.

\section{Sociology}

As the history of sociology began to mature in the 1980s and 1990s, Lynn McDonald, in Early Origins of the Social Sciences (1993), suggested most sociological themes and variations on those themes were deeply entrenched in Western intellectual history as early as the sixth and fifth centuries B.C. in Greece. The Peloponnesian War (approx. 431-404 B.C.) ${ }^{73}$ already encapsulated a sophisticated understanding of many methodological themes understood by sociologists today. ${ }^{74}$ Though the work of the NYS was in the late 1930s and early 1940s, the endeavor to understand human behavior is almost as old as civilization itself, reaching back to fifth-century Greece.

\footnotetext{
${ }^{71}$ Blaustein, Albert P. and Robert L. Zangrando, eds., Civil Rights and the American Negro: A Documentary History (New York: Trident Press, 1968), 328.

${ }^{72}$ Blaustein and Zangrando, 339.

${ }^{73}$ The Peloponnesian War written by Thucydides, considered the father of history, is acknowledged by historians as one of the earliest, if not the first, historical work.

${ }^{74}$ Lynn McDonald, The Early Origins of Social Sciences (Montreal: McGill-Queen's University Press, 1993), 19.
} 
In 1928, Pitrim Sorokin wrote sociology was divided into many areas, with different methods of cultivation of sociological knowledge growing in elementary and somewhat anarchical ways. He saw the field as a "half-wild national forest" rather than a carefully planned garden. Sorokin believed that standardization was especially dangerous, leading to a degeneration of real sociological knowledge into dry and lifeless statistics. He believed it was the complex nature of social phenomena that made necessary the various methods and approaches of the discipline. ${ }^{75}$

Though the history of the NYS offers a Braudellian ${ }^{76}$ view covering almost one hundred and fifty years of the rise of modern sociology, it is from the secondary literature that the depth and historical longevity as well as the position of sociology in the Western tradition arose. ${ }^{77}$ McDonald acknowledged Montesquieu's The Spirit of Laws (1748) as the first modern mainstream work of sociology. For Montesquieu, the social world was determined in the same way as the physical; its law was discoverable by observation and comparisons. As Newton discovered the fundamental laws of the physical world, Montesquieu discovered those of the intellectual. ${ }^{78}$ In the United States, the earliest instruction in "The Ends and Uses of Society" was offered by the College of Philadelphia in 1754, with a course in "Humanity" offered by Columbia University in 1794 by the

\footnotetext{
${ }^{75}$ Pitirim Sorokin, Contemporary Sociological Theories (New York; Harper and Brothers 1928), 757.

${ }^{76}$ Fernand Braudel was the leader of the Annales School and a leading advocate for approaching history with long view of events and contexts. According to Braudel, before the Annales approach, historians generally focused on a short span of time or on the history of specific events. J. H. Hexter, "Fernand Braudel and the Monde Braudellian...," The Journal of Modern History 44, no.4 (December 1972), 480483.

${ }^{77}$ McDonald, 75-76.

${ }^{78}$ McDonald, 147.
} 
university's professor of Greek. The catalog description read like an introductory course in sociology would a century later. ${ }^{79}$

Much of the writings in England and the United States have been bound with theological presuppositions, though sociological material has also been organized on its own. The first American to do so was Robert Hamilton Bishop, who taught the course “The Philosophy of Social Relations" at Miami University from $1834-1836{ }^{80}$ The first book to carry the word "sociology" in the United States was written by Henry Hughes, who in defense of slavery developed A Treatise on Sociology, Theoretical and Applied (1854). Similarly, the first work to use the term "social science" was written by Henry C. Carey, The Principles of Social Sciences, published in three volumes over the period 1858-1860. Influenced by English, Scottish, and German philosophers, Carey dealt with the primary factors affecting social life and social policy as well as the more formal analysis of rent, wages, and money. Carey's work gave rise to the American Social Science Association, which was organized to promote a "synthetic" view of social life and also had an active social reform platform. $^{81}$

As American scholarship began to move out of the shadows of Europe, Luis A. Coser suggested the dominance of the Chicago Department of Sociology, going back to the nineteenth century, came to an end in 1935 when the American Sociological Society, until then dominated by Chicago, established its journal, The American Sociological

\footnotetext{
${ }^{79}$ Becker, Howard and Harry Elmer Barnes, Social Thought from Lore to Science, Sociological Trends Throughout the World to the Start of the Twentieth Century's Seventh Decade (New York: Dover Publications, 1961), 953.

${ }^{80}$ Becker and Barnes, 954.

${ }^{81}$ Becker and Barnes, 954-955.
} 
Review. The connection and dominance of Chicago, both formal and informal, was permanently severed. The influence of Chicago persisted, however. Today it is one of many schools that has served as a foundation of sociology. From a historian's perspective, reasons for such disruptions and new connections reflect the historical moment and the political/professional turns in the discipline. The AYC was established in 1935 and swiftly moved toward the creation of the NYS in $1937 .{ }^{82}$

Talcott Parson, who became a major scholar in sociology with The Structure of Social Action (1937), was not immediately recognized by his peers in sociology though his work became a watershed in sociology and sociological theory, and set a new course. From the early 1940s to the middle of the 1960s, Parson's functional analysis became dominant in sociology and set the stage for and mimicked the work of the NYS ${ }^{83}$ Coser suggested that Parson's work, a synthesis of many European works, freed American sociology from ahistorical empiricism inherited from the "Chicago period." A major European scholar, Georg Simmel, was almost unheard of in the United Stated until Parson. Coser believed Parson attempted to develop a "voluntaristic theory of social action" through a synthesis of Emil Durkheim, Max Weber, and Vilfredo Pareto. The central features were:

1. Actors, capable of voluntary striving, emphatically not behaving and relating as bodies

2. Goals that these actors were striving for

3. Choices between alternatives means these actors were using in their pursuits

\footnotetext{
${ }^{82}$ Lewis A. Coser, Masters of Sociological Thought: Ideas in Historical and Social Context (New York: Harcourt, Brace, Jovanovich, 1977), 561.

${ }^{83}$ Functional analysis is the theoretical orientation concerned with the interrelations between social phenomena in general and, more specifically, with consequences of given items for the larger structure or structures in which they are variously embedded (Coser, 562).
} 
4. Situational constraints coming from both biological and environmental conditions, which set the bounds to the selection and means and the accomplishment of ends

5. Sets of norms and values that channeled the actor's choices of both means and ends. $^{84}$

Coser summed up Parson's work as viewing human actors as capable of making choices of courses of action, which are constrained by biological and environmental conditions. Parson believed values and norms govern the social structures in which they are variously enmeshed. ${ }^{85}$

\section{Black Sociology/Sociologists}

Parson's belief in governing social structures, influencing values, and norms has a significant association with African Americans and their fight for desegregation and racial equality. Living under legal segregation and racism generated a great concern about the demise of African Americans. The first major African American scholar to challenge the status quo was Du Bois, who pioneered work on racism and sociology. His work is now well known, but that was not always the case. In Black Sociologists: Historical and Contemporary Perspectives (2018), Marcus Anthony Hunter reflected upon the original 1974 work of Black Sociologists and offered new perspectives on "employing critical race theories and perspectives to assess, confess, and trouble the next enduring patterns of isolation and anti-Blackness that serve as the context within which Black sociology and sociologist are being produced." 86

\footnotetext{
${ }^{84}$ Coser, 563.

${ }^{85}$ Coser, 564.

${ }^{86}$ Mark Anthony Hunter, "The Sociology of Stuart Hall," in The New Black Sociologists: Historical and Contemporary Perspectives, ed. Marcus Anthony Hunter (New York: Routledge, 2018), xix.
} 
In a 1938 essay, "Blueprint for Negro Writing,” Richard Wright criticized African American literary and intellectual contemporaries for becoming too preoccupied with perceived sensibilities of White audiences. Wright saw two forms of African American writing that served as markers of respectability: conspicuous ornamentation and works that functioned as a platform for African American writers to plead with White America for justice. Wright saw the writings of his colleagues as not connecting with the African American masses in a significant way. Wright famously asked:

Shall Negro writing be for the lives and consciousness of the Negro masses [...] molding lives and consciousness of those masses toward new goals, or shall it continue begging the question of the Negro's humanity?" ${ }^{87}$

\section{History of Social Psychology}

Much of the work of Du Bois and the Black sociologists grew into the field of social psychology. ${ }^{88}$ Similarly, the work generated by the NYS in sociology, as well as its use in Brown, dealt with social psychology that analyzes how identity and the process of identification are rooted in their societal content of emergence. Early in mainstream American psychology, Whites implicitly supported the segregation of the two races on the measurable differences in personality traits and ability. The profession moved to a more dialectical approach following the work of Kenneth and Mamie Clark. Their work as well as the Brown decision made race an issue of ongoing debate within psychology. ${ }^{89}$

\footnotetext{
${ }^{87}$ B. Brian Foster, "Rewriting Wright: A Note on Perspective in Method and Writing," in The New Black Sociologists: Historical and Contemporary Perspectives, ed. Marcus Anthony Hunter (New York: Routledge, 2018), 18.

${ }^{88}$ Foster, 19-21.

${ }^{89}$ Philogène, 3-4.
} 
Observers of America from Alexis De Tocqueville (1835/1840) to Gunnar Myrdal (1944) have recognized the critical role race has in American society. Both saw race as a significant cultural marker that had infused almost every facet of American life and culture. It forms the underlying context for social exchange within and between groups. In 1944, Myrdal addressed the issue of African Americans' integration, demonstrating African Americans were institutionally marginalized solely by race, preventing them from assimilating and joining the mainstream in their pursuit of the American Dream. ${ }^{90}$

Gunnar Myrdal, a Swedish economist, published his massive study of blackWhite relations titled The American Dilemma $(1944) .{ }^{91}$ A huge collaborative effort sponsored and financed by the Carnegie Corporation, Myrdal's book became an instant classic while constituting a historic event. Helen and Robert S. Lynd, the noted coauthors of Middletown, ${ }^{92}$ called Myrdal's study “the most penetrating and important book on contemporary American civilization that has ever been written." ${ }^{93}$ Although Myrdal's book contained more than fifteen hundred pages with large amounts of data and hypotheses, one pervasive theme unified the work. Myrdal asserted that White Americans were experiencing a dilemma. Myrdal suggested that because of a discrepancy between the "American Creed," from which Americans thought, talked, and acted under the influence of egalitarian and Christian precepts versus the oppressive way they treated

\footnotetext{
${ }^{90}$ Philogène, 5.

${ }^{91}$ Gunnar Myrdal, The American Dilemma: The Negro Problem and Modern Democracy (Harper and Brothers: New York, 1944)

${ }^{92}$ Using the approach of social anthropology, the Lynds examined the city of Muncie, Indiana in the mid1920s. Their work became a bestseller and classic textbook for sociology.

${ }^{93}$ David W. Southern, Gunnar Myrdal and Black-White Relations: The Use and Abuse off An American Dilemma, 1944-1969 (Baton Rouge, Louisiana: Louisiana State University Press, 1994, xiii).
} 
African Americans, created a moral dilemma. That dilemma was exacerbated by the democratic rhetoric of WWII along with other social trends and would soon force a "fundamental change in American Race relations" and end America's greatest problem. ${ }^{94}$

Kenneth and Mamie Clark worked contemporaneously with Myrdal. The Clarks'

Doll experiments, ${ }^{95}$ demonstrated in Brown, highlighted to the nation the destructive influence of segregation and the power of social psychology to bring this injustice to light. The idea of identity for African Americans was crucial for the Brown decision. Following Du Bois's (1903) concept of dual consciousness, ${ }^{96}$ identification was one way to explain African Americans' ongoing struggle to enter the American mainstream, identifying themselves both as Americans and as members of a culturally distinct group. The Clarks illustrated how group identity formed in a broader social context. ${ }^{97}$ Frances Cherry, in her essay “Kenneth B. Clark and Social Psychology's Other History," suggested Clark's work was an outgrowth of his commitment to the actionoriented social psychology developing during the 1940s. In the post-WWII period,

\footnotetext{
${ }^{94}$ Southern, ivx.

${ }^{95}$ The Clark and Clark Study (1939) dispelled the long-held belief of racial ignorance in children by investigating the development of racial identification and skin tone preference. The participants consisted of African Americans of varying skin tones, age three to seven from Northern and Southern states. Each were asked to respond to eight statements by choosing one of four dolls (i.e., two black dolls and two White dolls). For questions one through four a majority of the children preferred the White Doll over the Black doll.

"Approximately two-thirds of the subjects indicated...that they like the White doll best or that they would like to play with the White doll in preference to the colored doll" (Clark \& Clark, 1939: 175). The Black doll was chosen more often for negative qualities and characteristics. For example, $59 \%$ of the children chose the Black doll as looking bad compared to $17 \%$ for the White doll for similar attributes. Finally, $66 \%$ of the children identified the Black doll as looking like themselves whereas the remaining $33 \%$ chose the White doll. (“A Modern Doll Study: Self Concept" (2017), Race, Gender \& Class, 24 (1), 186-202, 3).

${ }^{96}$ A concept Du Bois explored in The Souls of Black Folk; double consciousness describes the feeling one's identity is divided into multiple parts, making it difficult or impossible to have one identity.

${ }^{97}$ Philogène, 9.
} 
psychological social psychology parted ways with sociological social psychology as psychology began to favor the "methodological regime." ${ }^{98}$ Clark was not part of this movement, and though appealing to him, he did not choose to participate in it. For Clark, viable social psychology was one that attended to the differential power relationships introduced by Otto Kleinberg, one of Clark's mentors, which examined the more significant role of culture in personality and identity formation. ${ }^{99}$

The Clarks were also interested in the work of social scientists at Columbia who were shifting from race psychology to social psychology. Their studies in prejudice explored the nuances of the bigot as well as prejudice from the target's perspective. ${ }^{100}$ For Clark, the most important examination of social groups in real communities-was his community. ${ }^{101}$

\section{Philanthropy}

Daniel Gilman, Johns Hopkins first president and a founding member of the American Social Science Association (1865), suggested the philanthropists of the late nineteenth century had acquired more wealth that had had been previously accumulated and had acquired such a level of power and influence that there should be a recognition of a new force in philanthropy and civilization. This new philanthropy aimed to find longrange solutions to social problems instead of the traditional relief of the temporarily

\footnotetext{
${ }^{98}$ The practice of moving research from the field into the laboratory. The methodological regime advocated a much higher usage and reliance on statistics and more "controllable" experiments and data collection.

${ }^{99}$ Philogène, 21.

${ }^{100}$ Philogène, 21-22.

${ }^{101}$ Philogène, 23.
} 
destitute. ${ }^{102}$ Gilman identified two primary objectives of the new philanthropy. The first was the creation of a system of higher education second to none. The second was the rebuilding of the American South after the Civil War while educating the freemen. Oliver Zunz identified Georg Peabody's Fund for Southern Education as the first modern foundation and the beginning of the new philanthropy in the South. Peabody was later followed by the Slater Fund (1882), Rockefeller's GEB (1902), and the Julius Rosenwald Fund (1917). ${ }^{103}$

When considering the NYS and its social activities components, a discussion of the history of philanthropy is necessary. Central to the work of the NYS was the participation of the GEB, originally called the Negro Education Board (1937), which reflected John D. Rockefeller's mother, Laura Spellman's views, influenced by her parents who were abolitionists. Spellman College and Morehouse College were both started by the Rockefellers. ${ }^{104}$ For the majority of African American children in 293 of 912 Southern counties, the vocational schools created by Northern philanthropists represented the only primary education available. By 1929, there were 368 country training schools in the South. Slater Foundation and the GEB gave $\$ 135,866$ that year, and in total would give $\$ 1,888,852$ to public education in the South. ${ }^{105}$

\footnotetext{
${ }^{102}$ Harry S. Ashmore, The Negro and The Schools (New York: Van Rees Press, 1954), 10.

${ }^{103}$ Oliver Zunz, Philanthropy in America: A History (Princeton, NJ: Princeton University Press, 2014), 30.

${ }^{104}$ The General Education Board was philanthropy used primarily to support higher education and medical schools in the US, to help rural White and black schools in the South, as well as to modernize farming in the South. The Board, created by John D. Rockefeller and Frederick Gaines in 1902, \$180 million in aid. By 1934 the Board was making grants of $\$ 5.5$ million a year. It spent nearly all its money by 1950 and closed in 1964. Zunz, 31.

${ }^{105}$ Horace Mann Bond, The Education of the Negro in the American Social Order (New York: Octagon Books, 1966), 36.
} 
The role of philanthropy in the CRM was critical to the successes of the movement. The Jones Report and many other reports and programs could not have been undertaken without philanthropic support. The Jones Report required the assistance of the Phelps-Stokes Fund. Claxton, in his transmittal letter, explained the fund and its mission:

A fund found by Miss Caroline Phelps-Stokes, whose general interest in human welfare and a special interest in those who need help most led her to bequeath her fortune of almost a million dollars "for the education of Negroes, North American Indians, and deserving White students." In the spirit of this bequest the trustees of this fund have cooperated with the Bureau in making this fundamental study of the progress of education of Negros in the United States. ${ }^{106}$

Harry S. Ashmore reported on a 1953 study by the Fund for Advancement of Education (1953) partially supported by the Ford Foundation. Ashmore's writings are interesting as they occurred one year before the Brown decision. Ashmore clearly stated the Fund's purpose and its position was "apolitical."107

In the early twentieth century, African American public education gained a tremendous impetus from the contributions of philanthropists such as Rockefeller and Peabody. Through their efforts, African American children had access to over 5,000 schools in 883 counties in fifteen Southern and border states. The Rosenwald grants accounted for over 15 percent of the money spent on these schools, with 66 percent from public funds, 17 percent from direct contributions made by African Americans, and 4 percent from sympathetic Southern Whites. ${ }^{108}$

\footnotetext{
${ }^{106}$ Jones Report, $\mathrm{x}-\mathrm{xi}$.

${ }^{107}$ Ashmore, 6.

${ }^{108}$ Ashmore, 17.
} 
As part of the General Survey of the Jones Report, a list of agencies that contributed directly or indirectly to African American education were enumerated. Some of the organizations were:

- General Education Board

- Southern Educational Board

- Jeanes Fund

- Slater Fund

- Rosenwald Rural School Building Donations

- Phelps Stokes Fund

- Southern University Race Commission

- National Association of Teachers in Colored Schools

- Association of Negro Colleges

Without the level of support suggested by this partial list, the CRM would have had to spend a tremendous amount of time and energy to secure funding at the cost of its other activities.

The literature reviewed clearly suggests the centrality of Du Bois and the role sociology played in racial studies through to the 1930s. The NYS clearly aligned with prior and contemporaneous research, and became an active contributor to the efforts in both African American and White communities to address inequities in education. The literature suggests sociologists were clearly signaling that this problem was deeper than a question of equity. Racial segregation was damaging the emotional wellbeing of millions of African American children. As the sociologists of the time performed their experiments and surveys, they applied methodological rigor to answer their research questions. To answer the questions posed in this dissertation, I conducted historical analysis with a historiographical framework that covered the period under review. However, as noted earlier, this dissertation's framework spans both in education and history, requiring the use of methodological approaches from both disciplines. 


\section{CHAPTER III}

\section{METHODOLOGY}

K. Tobin and Joe L. Kincheloe (2006) offered a framework for investigating historical research in education served as a guide for my dissertation. In their work, Doing Educational Research: A Handbook, they defined history as:

As a detached endeavor, a quest for facts through an objective disposition. Historical writing tends to encapsulate a grand narrative, one that explained the event of the past without agents or procedures of knowledge; both the technicist and positivistic language usually frame such historical writing. ${ }^{109}$

The basis for doing history is the understanding that we do not exist in a theoretical vacuum. Emphasizing the lack of this vacuum is a citation from the noted European historiographer George Iggers's (2005) Historiography in the Twentieth Century: From Scientific Objectivity to the Postmodern Challenge. By referencing Iggers and also by citing the German/Holocaust historian Hans-Ulrich Wehler, a noted social historian from the Bielefelder School, ${ }^{110}$ Kincheloe strengthened his advocacy of a progressively transforming social change.

Kincheloe, McLaren, and Steinberg (2011), offering a caveat as a consequence of its many different and evolving theories, described critical theory as:

Critical research can be understood best in the context of the empowerment of individuals. Inquiry that aspires to the name critical must be connected to an attempt to confront the injustice of a particular society or public sphere within the society. Research becomes a transformative endeavor unembarrassed by the label

\footnotetext{
${ }^{109}$ Kenneth. Tobin and Joe L. Kincheloe, Eds., Doing Educational Research: A Handbook (Rotterdam: Sense Publishers, 2006), 68-69.

${ }^{110}$ The Bielefeld School was a group of German historians originally from Bielefeld University promoting social history and political history using quantification and the methods of political science and sociology. The leaders include Hans-Ulrich Wehler, Jürgen Kocka and Reinhart Koselleck who deemphasized the personalities of great historical leaders while concentrating on socio-cultural developments.
} 
"political" and unafraid to consummate a relationship with emancipatory consciousness. Whereas traditional researchers cling to the guardrail of neutrality, critical researchers frequently announce their partisanship in the struggle for a better world. ${ }^{111}$

Arcing back to Wehler and the Bielefelder School, the historian is reminded that the method and philosophy of historiography can raise critical consciousness and awareness in increasing the stake of personal interest to a collective involvement in history. A unique place to see this relationship is in our imagination. For traditional historians, this is dangerous ground, but when the argument is fleshed out, there is certainly a place for imagination in historiography.

Working in the texts of Hayden White (1990), Koselleck cited The Content of Form: Narrative Discourse and Historical Representation, where White warns the reader of the dangers of artistic license in the construction of a historical narrative. Though White strongly believed the actual objects or events of historical study put parameters on what can be imagined without additional corroboration from research, White was emphatic that contextual understanding is crucial in historical interoperation and studies. The utilizing of imagination is not an excuse to be romantic or essentialist. It is a tool to use language to stretch what language can do in capturing the nuances of time, lived experiences, and the sociopolitical context of history, while always being authentic to the primary sources. ${ }^{112}$

\footnotetext{
${ }^{111}$ Joe L. Kincheloe, Peter McLaren, and Shirley R. Steinberg, "Critical Pedagogy, and Qualitative Research: Moving to the Bricolage," in The Sage Handbook of Qualitative Research, $4^{\text {th }}$ ed., eds. N.K. Denzin and Y.S. Lincoln, (Los Angeles: Sage, 2011), 163.

${ }^{112}$ Reinhart Koselleck, The Practice of Conceptual History: Timing History, Spacing Concepts (Palo Alto: Stanford University Press, 2011), 9.
} 


\section{Historiography}

In the discipline of history, the foundation of answering the research question is anchored in historiography. As my dissertation bridges the disciplines of education and history, a discussion of historiography is warranted to understand the foundational methods for the history of education. What is the outcome of historiography? Its purposes are knowledge production made useful for the transformation of culture and society. Specifically, the purpose is to make the construction and content of history known. The insight and interpretations of history are crafted through the author's ability to ask basic questions about the responsibilities of governments, societies, communities, and individuals in crisis. ${ }^{113}$ Historiography brings out the social and political spirit through textual analysis and questioning of past practices. ${ }^{114}$

Along with the work of Du Bois, the Frankfurt School challenged the positivist methods of studying social, cultural, political, economic, psychological, and educational phenomena in the face of modern capitalism. Sociologists came to view discourses as expressions of power relationships within the sociohistorical realities they witnessed after the horrors of WWI. Sociologists:

Hoped, with their understanding of the constructed nature of social experience, was to move history past its concern for the past for its own sake and become part of the conversation on social change and democracy. Critical theory is concerned with issues of power and justice and the ways that the economy, race, class, gender, sexuality, religion, and other forces shape both educational institutions and individual consciousness." 115

\footnotetext{
${ }^{113}$ Koselleck, 10.

${ }^{114}$ Koselleck, 11 .

${ }^{115}$ Koselleck, $12-13$.
} 
The shaping of the individual within the broad context of society is representative of the NYS' foundational discussion as early as 1930 (see Appendix B).

Perhaps most germane to this dissertation is the work of African American historians of education who in the first half of the twentieth century saw no conflict between their scholarly goal of racial uplift and rigorous scholarship. These historians included W.E.B. Du Bois, Vincent P. Franklin, Carter Woodson, Horace Mann Bond, and others who had a deep connection to African American communities and viewed their work as part of a larger effort to save the oppressed. ${ }^{116}$ These scholars became members of the post-formalism movement, which attempted to democratize meaning-making while believing compelling interpretations emerging from the meaning-making process provide knowledge as a basis for action in the present. Critical history is a pragmatic history-a story of the past with consequences for the future and for the present. ${ }^{117}$

The work of these historians led to an enhanced human agency in which individuals and groups navigate a maze of social-cultural, political, economic, and educational structures that often serve to regulate and to discipline society. The first question for historians within Critical History is which groups and individuals are advantaged or disadvantaged by historical, educational plans and organizations. This assumes that the historian's training is stepped in the hegemonic, ideological, discursive, disciplinary, and regulatory modes of power and the ways humans' efforts shape their

\footnotetext{
${ }^{116}$ Koselleck, 14.

${ }^{117}$ Koselleck, 15 .
} 
own lives. ${ }^{118}$ This effort in Critical History aims to expand the possibility of finding new sources and developing ways of making sense of the past and its relation to the present. ${ }^{119}$

Post-formalism calls on historiography to include multiple perspectives in its discourse. Multilogicallity is the heart of critical multiculturalism and the notion of criticality. Kincheloe et.al described this notion of research as "bricolage." ${ }^{120} \mathrm{He}$ asserted social analysis, political perspectives, curriculum development, teaching and learning, and the field of education history are not esoteric academic points. Multilogicality educational history promotes a spatial distancing from reality that allows an observer different frames of reference. The process allows subjugated knowledge to emerge again to allow for the power of empathy in the cognitive process. Post-Formalism enables the observer to take a picture of reality from different vantage points, allowing for a form of analysis that moves beyond the isolated, decontextualized, and fragmented analysis of historical reductionism. ${ }^{121}$

An essential dimension of critical historiography is affirmative presentism, a venial sin for historians working with traditional historiography. While understanding that anachronistic judgment can be made by applying the ways of seeing of one era in another, affirmative presentism understands the complexity of the historical notion of seeing the past through the eyes of those in the past. When anchored to the documents of the past. The acknowledgment of an individual's social-cultural, political, and economic

\footnotetext{
${ }^{118}$ Koselleck, 16.

${ }^{119}$ Koselleck, 16-18.

${ }^{120}$ French for construction or creation from a diverse range of available items.

${ }^{121}$ Koselleck, 19-20.
} 
location in the present will always influence the individual's research. Affirmative historiographical presentism understands that the present always affords the past with meaning. ${ }^{122}$ The call for a better historical hermeneutic is clear:

The limits of this hermeneutics are the limitations placed upon any historical research. The temporal local that we inhabit, in particular, the social, cultural, political economic, the discursive present is our window on the past. The better we understand the present, the more rigorous our historical scholarship will be. The better our scholarship, the higher our understanding of how the present has come to be. ${ }^{123}$

Kincheloe sums up his argument with the African concept of "Sankofa," that refers to going back to understand the past to move forward. For Africans, Sankofa understands the past as not something lost over time but inseparable from the present and future. ${ }^{124}$

The post-WWI world was a time of great social upheaval and burgeoning world crises. It was an uncertain time for many that set the "frame of reference" for this dissertation that focuses on the late 1930s to the early 1940s. ${ }^{125}$ The period led to much indecision, confusion, and debate. Dixon Wecter, in The Age of the Great Depression: 1929-1941 (1948), identified the period as one where questions of economics and history, sociology, and social justice consumed vast amounts of time for those with intellectual curiosity. The debates centered upon the idea of social security to protect the individual

\footnotetext{
${ }^{122}$ Koselleck, 24.

${ }^{123}$ Koselleck, 25.

${ }^{124}$ Koselleck, 25.

${ }^{125}$ Historian Charles A. Beard stated: "It is that any selection and arrangement facts pertaining to any large area of history, either local or world, race or class, is controlled inexorably by the frame of reference in the mind of the selector and arranger" "Written History as an Act of Faith," American Historical Review, Vol. 39, No. 2, January 1934), 227.
} 
against harms beyond their control. So much so that the Roosevelt administration was looked toward as instigating the trend of increased government control and social planning. ${ }^{126}$

As the questions of racism and racial segregation are fundamental to any discussion on American society, the use of Critical Theory offers an interpretive model to understand the place of the NYS in the history of sociology and the CRM. Clearly, with scholars such as Du Bois, the primarily African American scholars of the NYS, and many of the sociologists who followed the period, their engagement in ending racial segregation situated them within critical theory. Though the NYS fit the framework of critical theory, the evidence of this fit was not widely known. In chapter four, I offer documentary evidence to support this claim collected from archival holdings containing over fifty thousand documents, representing a large-scale study conducted nationwide and subjected to the rigors of academic scholarship. This effort links the work of the NYS to that of Myrdal, Clark, and the NAACP's Legal Defense Fund, which argued the Brown decision of 1954 .

\footnotetext{
${ }^{126}$ Dixon Wecter, The Age of the Great Depression: 1929-1941 (New York: The Macmillan Company, 1948), 193.
} 


\section{CHAPTER IV \\ HISTORY OF THE NEGRO YOUTH STUDY}

\section{Introduction}

The story of the NYS is a largely forgotten history steeped in the development of many seemingly disparate efforts (civil rights, woman's rights, suffrage, anti-Eugenics, immigration, etc.) that came together with the initiation of the NYS in 1937. Those efforts began in the aftermath of the Civil War and Reconstruction. They are seen in the groundbreaking efforts of Du Bois as he worked in sociology, race studies, and black sociology, as they came into the public sphere in the interwar period with the Harlem Riots of 1935 and the NYS. The culmination of these efforts, for the purposes of this dissertation, was the work of the NAACP's Legal Defense Fund and the 1954 Brown $v$. Board of Education. The history and impact of the NYS reflect the role of social sciences in the CRM and the history of education.

The present dissertation takes a "long view" of its subject, as advocated by historian Fernand Braudel. The long runup to the NYS can be separated into three topical sections: the development of sociology, focusing on Du Bois and his Atlanta School; political/institutional interactions with critical historical events; and the work of the NYS itself within the context of the CRM. When brought together, these topics create a trajectory from Du Bois to the creation of the NYS, which places the NYS squarely within sociology's growing position in the CRM. After 80 years of obscurity, the NYS emerges once again.

In response to the horrors of the Civil War, the American Social Science Association (ASSA) formed in 1865 to develop techniques to ameliorate various social 
conditions. The ASSA was run mostly by amateur social scientists devoted to humanitarian causes; they added little to the knowledge base of the social sciences as an academic discipline. When the ASSA shifted its attention from helping victims of specific social changes to empirical inquiries into the processes affecting social change as a whole, it took the first steps toward professionalization. ${ }^{127}$

Scholars have noted a shift in rhetoric from the "individualism" and "egalitarianism" of the Revolutionary era to a hard-bitten group consciousness by the mid-nineteenth century as America entered the age of industrial manufacturing. ${ }^{128}$ Later in the century, the pseudo-science of phrenology ${ }^{129}$ took the nation by storm and was linked to Lamarckian genetics. This was the period of skull measurement and the infamous phrenological skull model. It was also at this time that American anthropology coalesced around evolutionary anthropology, inventing theories of racial "progress" in which most groups could never attain an equal status to the civilization of the White race. ${ }^{130}$ By the end of the nineteenth century, German-trained scientists began to arrive in the United States. They helped to formalize anthropology and challenged the entrenched theories of phrenology, eugenics, and racism. Those scholars, such a Franz Boaz, brought sociology and anthropology from the world of amateurs into the rigors of university

\footnotetext{
${ }^{127}$ Furner, 2.

${ }^{128}$ Thomas F. Cravens, Exploring Human Society: An Introduction to Sociology (Dubuque, IA: Kendall/Hunt, 1993), 186.

${ }^{129}$ Mid eighteenth-century pseudo-science predating Eugenics that held that by studying the shape and size of the human skull is a scientific indication of character and mental abilities.

${ }^{130}$ Cravens, $187-189$.
} 
academic departments. ${ }^{131}$ As social work became a separate profession in the $1910 \mathrm{~s}$, academics were left in charge of the field of sociology. As the field focused on resolving social problems, American sociology was sensitized to the "problems" of immigration and race in the late nineteenth century.

The twentieth century was difficult for the social sciences, as can be seen in the The Color Line (1905) by William Benjamin. Benjamin's work made it clear that sociology understood African Americans as racially inferior. That same year, Franz Boas, the father of sociology, attacked the notion that there were discrete races and dispelled the belief that each race was heading on its own evolutionary path. Humanity was one race with a long history of interracial sexual contact prejudice, not science. ${ }^{132}$

African American scholars were on similar trajectories, beginning with Du Bois and his work at Atlanta University's Sociological Laboratory/Conference Series. ${ }^{133}$ For sixteen years, Du Bois contributed to the foundation of American sociology, initiating what scholars would call black sociology. ${ }^{134} \mathrm{He}$ also ensured that the study of race and

\footnotetext{
${ }^{131}$ Cravens, 196.

${ }^{132}$ Herbert Hovenkamp, “Social Science and Segregation before Brown,” Duke Law Review 1985, no 3/4, 657-658.

${ }^{133}$ Eller, 171.

${ }^{134}$ Wright and Calhoun suggested a set of guiding principles discerned from conference papers produced over the 20-year life of Atlanta University's Conference Series:
}

Black Researchers must lead the investigations.

Research must focus on blacks.

Research must be interdisciplinary.

Findings must be generalized.

Research findings should have social/public policy implications. Earl Wright II and Thomas C. Calhoun, "Jim Crow Sociology: Toward and Understanding of the Origin and Principles of Black Sociology via the Atlantic Sociological Laboratory," Sociology Focus 39, no. 1, (2006), 5-6. 
racism formed part of sociology’s core. ${ }^{135}$ Much of Du Bois' career involved studying America's racialized world. His groundbreaking project The Philadelphia Negro: A Social Study (1899) was built from door-to-door surveys and interviews, featuring statistical charts and graphs. It loudly challenged writers such a Benjamin, and this work, in particular, prefigured the NYS in $1937 .{ }^{136}$ His work, along with the work of other scholars, created an academic discipline that became not only a foundation in the social sciences but also in educational research. However, nearly forgotten until the 1990s, Du Bois' engagement with academic sociology and sociological research was, for the most part, ignored by the discipline, especially the Chicago School. ${ }^{137}$

Du Bois held that sociology should be structured to initiate change. This understanding of sociology contrasted the Chicago School, whose scientific objectivity obscured prescientific assumptions of the inferiority of African Americans. By linking scholarship with activism, Du Bois became a center of efforts for social change and a pioneer in public sociology. ${ }^{138}$ Alan D. Morris suggested Du Bois' rejection of African American inferiority and assimilation, together with the development of public sociology, allowed Du Bois to construct a novel approach to race that prefigured current thought. ${ }^{139}$

\footnotetext{
135 Wright and Calhoun, 7.

${ }^{136}$ Eller, 171.

${ }^{137}$ Craig Calhoun, in Sociology in America: A History, ed. Craig C. Calhoun (Chicago: University of Chicago Press, 2007), 32.

${ }^{138}$ Aldon D. Morris, "Sociology of Race and W.E.B Du Bois," in Craig Calhoun, Ed., Sociology in America: A History (Chicago: University of Chicago Press, 2007), 504-505.

${ }^{139}$ Morris, "Sociology of Race," 505.
} 
Though sociologists may argue that their field originated with the Chicago School, scholarship since the 1990s has reevaluated the work of Du Bois, and he has gained prominence in the history of sociology to become the father of American sociology. In The Scholar Denied: W.E.B Du Bois and the birth of modern Sociology, Morris argued that it was Du Bois and not Robert Ezra Park who should be considered the founder, and that racism allowed for misrepresentation to continue into the 1990s. This denial of Du Bois' work, partially caused by Du Bois' comfort with communism before and during the McCarthy era, not only obscured the work of Du Bois but also of the following generations of African American scholars and their research. ${ }^{140}$

Morris demonstrated that Du Bois believed an authentic social science was indeed possible and there was no need to prove that superior and inferior races existed. Du Bois created the first laboratory to conduct systematic empirical research to determine the causes of racial inequality. The research generated was hypothesis based and objectively accepted or rejected. Morris argued that

Du Bois and his colleagues did indeed build a sociological school that challenged scientific racism by generating findings suggesting races were socially constructed and that social conditions largely determined racial inequality. Froma purely scientific perspective, Du Bois' school of sociology examining race was superior to the "scientific" research of the period - and of decades to come - that was based largely on conjecture, speculation, racist assumptions, and scant empirical data. ${ }^{141}$

Morris suggested that for "obvious reasons," White sociologists suppressed Du Bois's scholarship. To accept Du Bois' findings would have been a proclamation that the biological and cultural inferiority of African Americans was not supported by science. ${ }^{142}$

\footnotetext{
${ }^{140}$ Morris, Scholar Denied, 1.

${ }^{141}$ Morris, Scholar Denied 2.

${ }^{142}$ Morris, Scholar Denied, 3-5
} 
With the growth of Du Bois' Atlanta School, the next generation of African American sociologists came of age. Work, Wright, Haynes, Ovington and many others would produce highly visible and influential scholarly works. These scholars saw their work as essential, but the racism of White sociologists ensured the work of African American sociologists was obscured from the profession.

After Du Bois left the academy to join the NAACP, African American sociologists were associated with Park and the Chicago School. The most celebrated of them was E. Franklin Frazier, who eventually served as the first African American president of the American Sociological Society in $1948 .{ }^{143}$ Frazier and others openly acknowledged the debt they owed to Du Bois and the work he did in The Philadelphia Negro (1899). ${ }^{144}$ By the 1930s, positive changes in sociology's views on race had changed again for the worse. James McKee suggested sociologists of the 1930s moved from African Americans' innate inferiority to the idea of cultural inferiority. From either perspective, African Americans were viewed as inferior to Whites. ${ }^{145}$

\section{The Great Depression and Rising Social Concerns for American Youth Youth Disenfranchisement}

The effects of the Great Depression were felt across the country as early as 1930 . That year, the American Council on Education began discussions about creating a commission to study nongovernmental conditions affecting young people in the United

\footnotetext{
${ }^{143}$ Morris, Scholar Denied, 197.

${ }^{144}$ Anthony M. Platt, in The Negro Family in the United States, by E. Franklin Frazier, (Notre Dame, IN: University of Notre Dame Press, 2001), xiv-xv.

${ }^{145}$ McKee, 79.
} 
States. By September, the ACE announced the youth program and sponsorship for a 5year project. The GEB had granted $\$ 800,000$ for the program. President George F. Zook of the ACE and former U.S. Commissioner of Education sounded an alarm:

Recent social and economic changes in the United States have given rise to difficulties in the care and education of young people with which existing institutions are wholly unprepared to deal adequately.

The changes not only have greatly intensified the problems which confront the schools, but also have created an urgent need for protection and further education for millions of youths whom the schools are not reaching. Without some provision for continued basic planning to meet this situation, there is danger that present conditions may constitute a significant threat to the national welfare. The new organization will cooperate with all governmental, educational, and social agencies concerned with the youth problem. ${ }^{146}$

In Curriculum Principles and Social Trends (1969), J. Minor Gwynn noted that the AYC:

- Stimulated other studies;

- Did much to establish the basic techniques of making a youth and community survey

- Undertook studies in relatively new areas, such as family living, leisure, and recreation and showed that these areas were of paramount importance in influencing what a youth chooses and accomplishes in life

- For high school teachers, provided "well-sampled accurate studies of young people, their work, their problems, and their lives

- Recommended changes that could be made to adapt the curriculum to the needs and problems of youth. ${ }^{147}$

As identified in AYC documents, other accomplishments included:

- Influencing major officials in the U.S. Employment Service, resulting in more attention to young applicants and perhaps an increase in the number of employment offices throughout the country;

- Shaping Civilian Conservation Corps (CCC) procedures

- Influencing the move to unite the National Youth Administration and the CCC under one head. ${ }^{148}$

146 "Minutes of the Meeting of the Committee on Problems and Plans in Education, 21-22 November 1930,” NYS Paper, Box 78, Folder Problems and Plans Committee 1930.

${ }^{147}$ Minor and Chase, Curriculum Principles and Social Trends, 25, 374, 511.

148 "Report of the Acting Director," NYS Papers, Box 78. 


\section{Analyzing the Origins, Ambitions, and Outcomes of the Negro Youth Study}

The Commission began in 1935 with a concern for "circumstances of the period": Thousands of youth were roaming the country as destitute and high schools in almost every community dealt with sudden enrollment increases at a time when school taxes often went unpaid and school budgets were being slashed. There was a great deal of anxiety about the millions of youth who neither in school nor entering the workforce. ${ }^{149}$

The "emerging" youth problem surfaced because educational institutions sounded an alarm as they dealt with the burgeoning problem. The ACE saw this problem as a crisis and funded the commission with money from the Rockefeller Foundation's GEB. The commission had considerable latitude in addressing and reporting on the youth crisis. ${ }^{150}$

The AYC was immediately hampered by a lack of factual information. The first steps were to collect previous research, organize fact-finding conferences, and conduct fieldwork to generate data. According to the authors of the 1942 report Youth and the Future, ACE's “Youth Tell Their Story (1937)," was vital to the commission over its seven-year lifespan. It was the first sociological study that based its conclusions on a large-scale field survey. The study concluded that there were four million unemployed youth, and census data later verified these findings. ${ }^{151}$ When faced with such high youth unemployment, the commission members first imagined the American economy would soon rebound. While hoping that American economic power would return, the commission embarked on a thorough study of conditions that could be improved by

\footnotetext{
${ }^{149}$ Youth and the Future: The General Report of the American Youth Commission (Washington, DC: American Council of Education, 1942), ix.

${ }^{150}$ Youth and the Future, $\mathrm{x}$.

${ }^{151}$ Youth and the Future, xi.
} 
changing social "facilities" in order to smooth the path through high school and into a job. ${ }^{152}$

The November 1935 issue of Occupations: The Vocational Guidance Magazine contained a brief account of the first meeting of the AYC. The director of the National Youth Administration participated in the initial meeting of the AYC, which was addressed by AYC director Homer Price Rainey, president of Bucknell University. Rainey made eight recommendations that served as an informal guideline for the future program (see Appendix D).

Concerns about the state of education and African American education in particular had already been noted as early as a synopsis of the January $14^{\text {th }}, 1930$ meeting. The commission noted that the seventeen African American land colleges in the Southern states covered an area containing ten million people and had received $\$ 338,000$ of the $\$ 13,000,000$ in federal grants tied to the land grant institutions. This financial allocation one-fortieth of the total promised money to serve one-tenth of the U.S. population at the time. In the last sentence of the paragraph containing these statistics, the committee noted that "not one of these seventeen institutions come near the standards maintained or covering the area of service rendered by White colleges."153

The question of how to fund African American colleges and universities centered on the First and Second Morril Act. ${ }^{154}$ The first Morril Act was the federal basis for the

\footnotetext{
${ }^{152}$ Youth and the Future, $\mathrm{x}-\mathrm{xi}$.

${ }^{153}$ Youth and the Future, xiii.

${ }^{154}$ Sponsored by Vermont Congressman Justin Morril, the act was signed into law by President Abraham Lincoln on July 2, 1862. Officially titled "An Act Donating Public Lands to the Several States and Territories which may provide Colleges for the Benefit of Agriculture and the Mechanic Arts," the Morrill Act provided each state with 30,000 acres of Federal land for each member in their Congressional
} 
creation of land grant colleges, which contained no provisions for African American colleges. In the Second Morril Act, the federal government prohibited the distribution of money to states that made distinctions of race in admissions unless the states establish at least one land-grant college for African Americans. However, once created, the African American schools were received very little of the funding. African Americans did not ask for the funding to White schools be reduced. Rather, they asked that funding for African American schools be equitable with respect to the White schools. ${ }^{155}$ However, the second Morril Act stipulated that states should create experimental stations and agricultural extensions within land grant colleges. African Americans were denied such opportunities and only participated in them as laborers. The committee relayed the belief that "Negro supervision of Negroes works better. Negroes are adept at fooling Whites." ${ }^{" 156}$ Despite some ambiguous statements that leveled complaints against African Americans while pleading for better treatment, both the ACE and the nation sped up efforts for improvements following some of the first race riots.

On September 16, 1935, a group of education professionals and leading citizens were at a conference, and sitting on a table was a pamphlet entitled "A Proposal for the Development of a Comprehensive Program for the Care and Education of American

delegation. The land was then sold by the states and the proceeds used to fund public colleges that focused on agriculture and the mechanical arts. Sixty-nine colleges were funded by these land grants, including Cornell University, the Massachusetts Institute of Technology, and the University of Wisconsin at Madison. Primary Documents, Library of Congress, Web Guide, https://www.loc.gov/rr/program/bib/ourdocs/morrill.html retrieved 18 May 2019.

155 "Circular to National Advisory Committee on Education: Conference on Negro Education, Jan 14, 1930," ACE Papers, Box 57, Folder National Advisory Committee on Education, Committee on Negro Education, 3.

156 “National Advisory Committee on Education.” ACE Papers, Box 57, Folder National Advisory Committee on Education, Committee on Negro Education, 4. 
Youth." It stated, "to a degree unprecedented in its history, the United States needs a thoughtfully conceived, and well-coordinated plan of action for the care and education of its adolescent boys and girls and its older youth." ${ }^{157}$ This was the first proposal for the future creation of AYC. Within this proposal for the AYC was a second proposal that offered suggestions for specific field studies within the AYC. The largest and most wellknown of these proposals led to the creation of the NYS.

In the surge to work with America's children and with a particular interest in African American students, the archival records suggest that at no time before 1935, nor after WWII, was the ACE ready to support such efforts. The context of the Great Depression, almost forty years of de jure segregation and the expectation of African Americans following WWI created both a push and pull to ameliorate the situation facing African American children during the depths of the Depression. The push from African Americans may appear obvious, but it is less clear why Whites felt the time to end of segregation was upon them. Of note is a sense of fear that the conditions within the African American community, if not all minority communities, was approaching a time of confrontation.

Suggestive of such simmering conditions in the African American community was the work of two New York City commissions following the wake of the 1935 and 1943 riots in Harlem. Both commissions suffered from poor community support, and in the aftermath of the 1943 commission, the work of the 1935 commission was brought in the discussion to ask about its effectiveness in not being able to prevent the next riot that

\footnotetext{
157 “A Proposal for the Development of a Comprehensive Program for the Care and Education of American Youth, September 16, 1935,” ACE Papers, Box 57, Folder AYC, 1.
} 
would take place in 1943. From the 1935 commission report, a troubling window opened upon the conditions facing African Americans in the Great Depression. ${ }^{158}$

From August 1 to August 2, 1943, a riot took place in Harlem resulting in six fatalities, seven hundred wounded, and six hundred men and women arrested. ${ }^{159}$ The Harlem Riots of 1943 followed a similar incident in 1935 and had been brewing for many years. For the previous eight years, the question of what could be done to help ameliorate the economic, social, and racial issues in the minds of many of the city's progressiveleaning citizens. The problems manifested in the 1943 race riot and the child welfare system were present in 1935 when New York City experienced the first identified race riot. ${ }^{160}$ In 1935, a Puerto Rican teenager was arrested and accused of shoplifting. Rumors spread throughout Harlem that the police had beaten and possibly killed him in the basement of a department store on $125^{\text {th }}$ Street. Quickly a riot broke out, known as the Harlem Riots of 1935. In response to the riot, New York's mayor created a commission of noted Whites and African Americans among whom was Fisk University sociologist E. Franklin Frazier, later a significant contributor to the NYS. The committees documented the social, economic, health, and housing conditions in the "capital of Negro America."161 The group's "Economic and Social Survey" provided one of the first comprehensive

158 “Harlem Disorders Bring Quick Action by City and Army: Police and Soldiers Patrol the Area, New York Times, August 2, 1943, 1.

${ }^{159}$ Nat Brandt, Harlem at War, (Syracuse, NY: Syracuse University Press, 1996), 207.

${ }^{160}$ Race Riot is understood as a public disorder where the crowd, identifying itself with a particular race, commits acts of indiscriminate violence and goes on the rampage targeting buildings and other racial groups simply by their identification as "other." This is in opposition to riots up this point where mayhem was meted out without any calculations as to race or ethnicity.

${ }^{161}$ Gerald E. Markowitz, Children, Race, and Power: Kenneth and Mamie Clark's Northside Center (Charlottesville, VA: University of Virginia Press, 1996), 5. 
studies documenting the social, economic, health, and housing conditions for those living in Harlem. ${ }^{162}$ The core question the survey raised was how to recognize and remedy the conditions within the New York City African American community believed to be contributory factors in African Americans youth's high rate of crime and antisocial behaviors.

The survey results suggested the harshness of life experienced by African American youth aligned with the view social scientists had of racial prejudice as an irrational attitude that grew from stereotypes about race, and was a psychological phenomenon. In 1936, the work of Eugene Horowitz suggested the social sciences should move their focus from the study of adults to the study of young children to understand the origins of racial prejudice. Horowitz demonstrated that racial prejudice was a learned behavior and found that children as young as five or six could develop racial hostility to “outgroups."163

On March 19, 1936, on the first anniversary of the Harlem Riot, the Mayor's Commission on the Conditions in Harlem issued a report with findings and recommendations in the wake of the first modern race riot in the United States. In the forward to the 116-page report, keywords quickly suggested the problems present in Harlem needing immediate redress: "Negro problem," "Civil liberties," "Police and the treatment of Harlem," and "Social justice." ${ }^{164}$ Moving quickly into eye-witness accounts,

\footnotetext{
${ }^{162}$ Markowitz, 6.

${ }^{163}$ Jackson, 28-29.

164 "The Negro in Harlem: A Report on Social and Economic Conditions Responsible for the Outbreak of March 19, 1935," Frazier Papers, Box 131-117, Folder 3.
} 
a self-identified professional stated, "Those poor ignorant and rough Negroes on $125^{\text {th }}$ Street were fighting my battle." In the commission's report, these words spoke of the general mood and temperament of the community. ${ }^{165}$ The commission sought to identify the causes behind the fury on the streets and why Lloyd Hobbs, "a boy, having a good record both in school and in the community, and being a member of a family of good standing and character, [had] left the impression upon the community that the life of a Negro is of little value in the eyes of the police."166

Immediately following 1935 riot, the Harlem community quickly became despondent as the police response seemed heavy handed and insensitive at best. The increased police presence, after the riots, symbolized to residents that their protests of March $19^{\text {th }}$ fell on deaf ears and that the protection of property outweighed the demands of the community for work and decent living conditions. ${ }^{167}$ The many conditions were delineated on the next page. The economic conditions included lack of safe housing, racial discrimination, public health, and the situation in the schools. ${ }^{168}$ The physical condition of the schools was described as "disgraceful" and leading to a high rate of truancy. Connected to the rundown schools was a lack of recreational facilities that the report noted along with "vicious" environments surrounding the schools; "all indicate the

165 "The Negro in Harlem: A Report on Social and Economic Conditions Responsible for the Outbreak of March 19, 1935," Frazier Papers, Box 131-117, Folder 3, 11.

\footnotetext{
166 "The Negro in Harlem: A Report on Social and Economic Conditions Responsible for the Outbreak of March 19, 1935," Frazier Papers, Box 131-117, Folder 3, 10.

167 "The Negro in Harlem: A Report on Social and Economic Conditions Responsible for the Outbreak of March 19, 1935," Frazier Papers, Box 131-117, Folder 3, 109.

168 "The Negro in Harlem: A Report on Social and Economic Conditions Responsible for the Outbreak of March 19, 1935," Frazier Papers, Box 131-117, Folder 3, 114.
} 
presence of a poverty-stricken and therefore helpless group of people in the

community."169

After 114 pages of the background and research into the causes of the Harlem

Riots, the commission made an ask of the New York Police Department:

While one would not expect the policemen in Harlem to show any appreciation of understanding of the sociological factors responsible for crime in the community, the discipline of the Police Department should see to it that they do not become the persecutors of and oppressors of the citizens of the community. Nevertheless, it is true that the police practice aggressions and brutalities upon the Harlem citizen not only because they are Negroes but because they are poor and therefore defenseless. ${ }^{170}$

In closing the report, the commission offered twenty-eight sweeping recommendations to alleviate the conditions in Harlem that had fueled the deep resentment toward the city government and the police in particular that exploded during the riots (see Appendix E).

African American newspapers were scathing in their response:

What were the police doing when Negroes were being beaten in the Negro district? Arresting Negroes. What were the police doing when cars were stopped by the mob and Negroes mobbed and beaten? What were the police doing when automobiles bearing Negroes were stopped, turned over and demolished and their occupants were beaten? They were arresting Negroes. ${ }^{171}$

How grave were the community's concerns? In the papers of E. Franklin Frazier

housed at Howard University, is a five-page letter from Samuel Hazzard of 45 East $145^{\text {th }}$

Street in New York City. Hazzard was a resident of Harlem and had experienced the riot

\footnotetext{
169 "The Negro in Harlem: A Report on Social and Economic Conditions Responsible for the Outbreak of March 19, 1935," Frazier Papers, Box 131-117, Folder 3, 115.

170 “The Negro in Harlem: A Report on Social and Economic Conditions Responsible for the Outbreak of March 19, 1935," Frazier Papers, Box 131-117, Folder 3, 115-116.

${ }^{171}$ Alex Swan, "The Harlem and Detroit Riots of 1943: A Comparative Analysis", Berkeley Journal of Sociology 16 (1971-72), 86. as cited in P.L. Prattis, Pittsburgh Courier, July 3, 1943, as printed in "The Negro Press on the Riots", Common Ground, IV, Autumn, 1943, 101.
} 
of 1935 and wrote to Mayor Fiorello LaGuardia that "the situation will develop into blood-shed if nothing is done." ${ }^{172}$ Hazzard, who wrote in his letter that he was not using his real name or address, identified himself as a "colored, naturalized US citizen of West Indian birth." His main concerns were the "ignorant young Negroes" who were agitating on the corners of $133^{\text {rd }}$ Street and Lenox Avenue for the murder of " 25 Italians in order to enter the kingdom; 50 Italians to go to the altar, and 100 Italians to approach the throne." ${ }^{173} \mathrm{He}$ later wrote of a speaker who "sometimes concludes his meetings with a blasphemous prayer in which he asks God to help him and others to kill thousands of Whites and their babies." ${ }^{174}$ The background to this was the Italian invasion of Ethiopia that had energized the African American community in Harlem. Hazard referred to the March 19 riot as an "uprising" and finished his letter with a postscript:

Today an automobile carrying a huge placard, written in large letters. This is what it said in part: "Japan calls Negroes to Race War." The publication is known as the Harlem Bulletin-I mean the publication that is sponsoring this propaganda cited above. I don't think you want a Race War which would bring Retaliations with death or injury to some innocent member of both groups. ${ }^{175}$

The letter packs a large amount of history in just a few pages. There were references to churches, Garveyites, and the NYPD, and many references to dark or light skinned youth who were just one percent of the population bent on agitating. ${ }^{176}$ The everpresent White fear of an African American uprising or race war were understood in the

\footnotetext{
172 “Mayor LaGuardia to Dr. Roberts," Franklin Papers, Box 131-117, Folder 9.

173 “Mayor LaGuardia to Dr. Roberts," Franklin Papers, Box 131-117, Folder 9.

174 “Mayor LaGuardia to Dr. Roberts,” Franklin Papers, Box 131-117, Folder 9.

175 “Mayor LaGuardia to Dr. Roberts," Frazier Papers, Box 131-117, Folder 9.

176 “Mayor LaGuardia to Dr. Roberts," Frazier Papers, Box 131-117, Folder9.
} 
African American community. Hazard's prediction of bloodshed came true in spite of the efforts of LaGuardia and others who, noting the conditions of African Americans, attempted to steer African American youth on the path to jobs, security, and equality.

The NYS was organized in the wake of the Harlem Riots and La Guardia's commission with major funding from the AYC. ${ }^{177}$ The Mayor's commission was a sixteen-person panel convened by the ACE to bring together the nation's foremost social science researchers to examine concerns facing America's youth. ${ }^{178}$ The AYC's charge to the NYS was to investigate the question of how best to educate and socialize African American youth. With rising tensions evident in the African American community, academics aimed to address the problems of the community. Unfortunately, the politics of academic research were about to end the twenty-five-year dream of one of its significant scholars and open the door for the NYS.

\section{A Defining Moment: Assessing Du Bois' Relationship to the Social Sciences}

In 1937, Du Bois was passed over as the editor for An America Dilemma.

Concurrently, he had been working for over two and a half decades on a the projected

\footnotetext{
${ }^{177}$ ACE's Youth Commission was formed in 1935 to conduct a nationwide study of the issues and concerns of American youth. The Commission researched standing educational programs to determine if improvements could be made to accommodate societal changes. The Commission considered increased leisure time, advances in the technology in transportation, radio and film, and employment opportunities in their large studies. Of particular interest to The American Youth Commission was rural youth, African American youth, and youth in the criminal justice system. The American Youth Commission Study was the most significant undertaking of the Council. Its charge was to consider the relative neglected needs of 16 to 24-year-olds.

${ }^{178}$ Since 1917, ACE had been the major coordinating body for the nation's colleges and universities, is a membership organization that mobilizes the higher education community to shape effective public policy and foster innovative, high-quality practice. Our strength lies in our diverse base of member institutions. We represent over 1,700 college and university presidents and the executives at related associations, and are the only major higher education association to represent all types of U.S. accredited, degree-granting institutions: two-year and four-year, public and private. Our members represent two out of every three students in all accredited, degree-granting institutions. Retrieved, 17 May 2019, https://www.acenet.edu/about-ace/Pages/default.aspx
} 
The Encyclopedia of the Negro. In the first half of the 1930s, Du Bois thought he saw a rejuvenated spirit in the philanthropic community to fund such a significant study. In 1932, the Phelps-Stokes Fund did initiate a movement to produce the study but did not name Du Bois as editor. Outraged African American scholars protested to the Fund, that Du Bois be a part of the study. In 1934, Du Bois was appointed as editor in chief. ${ }^{179}$

By 1937, Du Bois has secured a $\$ 125,000$ pledged from Phelps-Stokes to cover half the costs for the encyclopedia. He then applied to the GEB for the other half. The Rockefeller-controlled GEB rejected Du Bois' proposal, and following several years of political maneuvering between various funders, scholars, and public acrimony, theproject was never started. Myrdal's study supplanted it as the Carnegie Foundation decided to pursue a different direction. Morris argued that "nervousness" over Du Bois's radicalism and allegations he and his African American colleagues lacked scientific objectivity suggested the need for a new study led by a White scientist from outside the United States. ${ }^{180}$ A few months later, the GEB funded the newly-created NYS, which had structural roots in the work of Du Bois and mimicked the suggestions he made concerning a black sociology and black sociologists.

In his essay "Rewriting Wright: A note on Perspective in Method and Writing (2018)," B. Brian Foster cast a wide net on why this situation developed. To the African American scholars, he saw that they, too, were part of the problem. In a 1938 essay, "Blueprint for Negro Writing," Richard Wright criticized his African American literary and intellectual contemporaries for becoming too preoccupied with perceived sensibilities

\footnotetext{
${ }^{179}$ Platt, xiv-xv.

${ }^{180}$ Platt, 208-209.
} 
of White audiences. Wright saw two forms of African American writing that served as markers of respectability: conspicuous ornamentation and works that functioned as a platform for African American writers to plead with White America for justice. Wright saw the writings of his colleagues as failing to connect with the African American masses in a significant way. Wright famously asked, "Shall Negro writing be for the lives and consciousness of the Negro masses...molding lives and consciousness of those masses toward new goals, or shall it continue begging the question of the Negroes' humanity."181

In his essay, "The Sociology of Stuart Hall (2018),” Mark Anthony Hunter discussed the next generation of black sociologists, focusing on Stuart Hall. Hunter suggested that the baton of black sociology was passed from Du Bois to Hall. Why? In 1951, Du Bois was charged as a foreign agent by the U.S. Government and was taken to task for his affiliation with communism. The news was loud, widespread, and deadly for Du Bois's career and the legacy of his work. Ultimately exonerated of all charges, Du Bois left America for Accra, Ghana, where he lived until his death. ${ }^{182}$

As the years from 1935-1937 were formative in the development of the NYS, Morris's discussion of the Du Bois' marginalization during the creation of Myrdal's An America Dilemma and The Encyclopedia of the Negro is critical to understanding the moment that the NYS emerged. The impetus for the Carnegie Foundation's support of a comprehensive study on the race issue, Morris argued, was the fear of the philanthropy community of the "restlessness" of African Americans as they confronted lynching and

\footnotetext{
${ }^{181}$ Foster, 22-23.

${ }^{182}$ Mark Anthony Hunter, "The Sociology of Stuart Hall," in The New Black Sociologists: Historical and Contemporary Perspectives (New York: Routledge, 2018), 49.
} 
racial "denigration"; African American men put on the uniform of the U.S. armed forces only to find racism in a segregated military. The fear of these and other conflagrations weighed heavily on the minds of many, and these tensions spurred the philanthropic community to open its coffers for a comprehensive study on race. A White, Norwegian scholar was chosen for the task; Gunnar Myrdal was thus forever linked to An American Dilemma, a study that had its roots in the work of Du Bois thirty-five years earlier. ${ }^{183}$

\section{Rockefeller's General Education Board: Resurrecting Traditions of American}

\section{Progressivism in the Postwar World}

The Rockefeller Foundation's General Education Board (GEB) was also worried about the disenchantment of African American youth; it became the primary funder of the NYS. The GEB sought to determine the impact of racial discrimination on the personality of African American youth, and it saw the NYS as a vehicle to drive the project. The work of both organizations reflected the burgeoning cooperation of sociology, anthropology, and psychology in the study of race relations.

The GEB was founded in 1902 by John D. Rockefeller Jr. and Frederick Gaines with the expressed purpose of "the promotion of education within the United States without distinction of race, sex, or creed," ${ }^{184}$ this philanthropic creation had deep roots in the Rockefeller family's connection with public education and worked with AfricanAmericans to support K-20 education as John D. Rockefeller's father was influenced by

\footnotetext{
${ }^{183}$ Platt, 199.

${ }^{184}$ Raymond B. Fosdick, Adventure in Giving: The Story of the General Education Board, A Foundation Established by John D. Rockefeller (New York: Harper and Row, 1962), 7-8.
} 
his efforts as a conductor on the Underground Railroad. ${ }^{185}$ The GEB used philanthropy to support higher education and medical schools in the United States, to help rural White and African American schools in the South, and to modernize farming in the South.Upon its founding, Rockefeller gave $\$ 180$ million. By 1934, the Board was awarding grants of more than $\$ 5.5$ million a year through 1950 and ceased operations in $1964 .^{186}$

The catalyst behind the AYC was the realization of the GEB that as the Depression struck the country workers at both ends of the wage scale would be significantly affected. It also became apparent that nearly 250,000 high school students out of work and "on the road" were now heading back to school. The GEB noted a paralysis in the American educational system, which was not equipped for the Great Depression. The education system faced challenges in upgrading the curriculum to more modern and advanced subjects, as well as challenges to its tax base as the Depression deepened and panic set in. ${ }^{187}$ In response to the situation, the GEB envisioned a five to ten-year program involving a $\$ 10$ million expenditure. In 1933, the GEB authorized the project, and two years later, AYC created AYC and would contribute $\$ 1,350,000$ over the next seven years. ${ }^{188}$ Among the issues the GEB addressed was the problems facing African American youth, as articulated by sociologists, psychologists, anthropologists, and educators. By 1941, the NYS produced seven relevant studies. From the several

\footnotetext{
${ }^{185}$ Fosdick, 5 .

${ }^{186}$ Fosdick, 242-245.

${ }^{187}$ Fosdick, 240-241.

${ }^{188}$ Fosdick, 244.
} 
hundred case studies the NYS conducted, "a vivid picture of the way African American boys and girls emerged based upon the hue and pigmentation of their skin." 189

In a folder labeled "Committee on Education of Minority Racial Groups 19431948," documents show that the ACE sounded alarms once again. In a letter to ACE president George F. Zook, New York Commissioner of Education George D. Stoddard described a meeting in his office with Will Alexander, Dean Robert Redfield, and Professor Ralph Bunche of Howard University that followed up a meeting of ACE's Problems and Plans Committee. In an outline written by Dean Redfield, the group wanted to:

Assess the waste in human resources which was going on in connection with the more important racial minority groups and at the same time to look into those situations where decided improvements had been made in the situation, those putting into the proposed report a positive as well as a negative note. ${ }^{190}$

Stoddard's objective in the letter was to create a proposal for the GEB. The support of the GEB would be crucial for the efforts of both the AYC and NYS.

\section{Promoting New Agendas and Methods: Gunnar Myrdal and the Social Sciences of the late 1930s and Early 1940s}

By 1939, sociology, following on the work of Melvin J. Herskovits and others, explained what had been viewed as innate racial difference as only apparent differences. ${ }^{191}$ Building upon the work of Boas, the beginning of the end of racist anthropology came in the late 1920s through the work of Herskovits, who was a student

\footnotetext{
${ }^{189}$ Fosdick, 245.

190 "Letter from Zook to George D. Stoddard," 10 February 1944, ACE Papers, Box 130, Folder: Committee on Education of Minority Racial Groups 1943-1948.

${ }^{191}$ Jackson, 4.
} 
of Boas. In his book, The American Negro (1928), Du Bois discredited many long-held scientific ideas about the physical and mental abilities of African Americans. For Herskovits, recognizing individuals of a specific racial group as having unique characteristics was very different from making value judgments about racial superiority. ${ }^{192}$ Gunnar Myrdal's monumental 1944 publication of the study on race relations, An American Dilemma: The Negro Problem and Modern Democracy, ended much of the lingering debate. This fifteen hundred-page book contained forty-six chapters and six appendices containing the research of almost every scholar on race, listing more than seventy-five researchers as members of its staff. ${ }^{193}$

Myrdal's work came to the public in 1944, but he and the NYS had a relationship from the beginnings of his research. In 1939, Robert Sutherland had a meeting with Myrdal and reported his discussion to the NYS. Sutherland noted there was "so much attention being given to the Negro by research foundations" that the NYS was tracking how not to duplicate Myrdal's research. However, Sutherland stated the NYS would be distinctive and not rehash previous work. He went as far to suggest that this course might steer from the general outline stated a few years earlier in his proposal to ACE ${ }^{194} \mathrm{On}$ February 10,1939, Myrdal wrote to Frazier asking him to comment on early work Myrdal had written in An American Dilemma. The Frazier Papers contain significant

\footnotetext{
${ }^{192}$ Herbert Hovenkamp, "Social Science and Segregation before Brown”, Duke Law Review 1985, no 3/4, 657-658.

${ }^{193}$ Myrdal found hypocrisy in America's treatment of African Americans as it fought Germany. America saw African Americans as blacks first and doubted their status as fully American. Along with extensive personal travels across America, Myrdal amassed a tremendous amount of field research and secured the work from over 75 social science researchers.

194 “Memorandum from Sutherland to Directors of NYS," Frazier Papers, Box 131-25, Folder 25,
} 
correspondence between them suggesting the NYS and Myrdal coordinated and kept informed about each other's work. ${ }^{195}$

By the 1940s, social scientists, having disproved the genetic basis for racism, had shifted to antipathy between the races which they had long explained as pointing to inherent differences between the races. They believed "Whites would 'naturally' dislike close contact with an inferior race." ${ }^{196}$ While rejecting racial difference, the sociologists had a difficult time explaining racial antipathy. Social Sciences attempted to measure racial prejudice quantitatively, linking it to personal traits and identifying its origins in childhood development. ${ }^{197}$

Coming out of the 1940 s, sociologists represented a powerful weapon for battling racism in the postwar United States, as sociology represented a "scientific viewpoint" on segregation. For social sociologists, the CRM was a chance for sociology to influence the governing of society. The CRM also provided an avenue for sociology to change law and society's view on the "race problem." It courtrooms, sociologists demonstrated their ideas to the general public and convinced America that sociologists were superior to the "common sense" of the individual. ${ }^{198}$ In the interwar years, the view of racial prejudice in the social sciences shifted from one of rational response to irrational responses to the changes in the social world.

\footnotetext{
195 “Myrdal to Frazier, February 10, 1939," Frazier Papers, Box 131-40, Folder 10.

${ }^{196}$ Hovenkamp, 671.

197 Jackson, 5.

${ }^{198}$ Jackson, 8
} 
Before WWII, social science was often hesitant to recommend legal changes to society. Following WWII, sociologists went far in claiming that races were all equal and segregation was not a natural response to avoid members of another race-children had to be taught racial prejudice. The social scientists also claimed that the law should require rapid desegregation, giving no time for gradual adjustments. However, these were not the prevalent views of America before Brown. ${ }^{199}$ Social scientists built an argument that the laws could shape and change attitudes held by society. ${ }^{200}$ By 1948 , the Supreme Court was ready to bring sociology into American jurisprudence. In Shelley v. Kraemer (1948), ${ }^{201}$ the court held unconstitutional racially exclusive property covenants partially through the presentation of the new environmental racial science. The petition to the court relied heavily on cultural relativists, with a heavy dose of Herskovits and Myrdal. In an amicus brief, the Congress of Industrial Organizations (CIO) argued that the races were "creations of the investigator and creations with regard to which all the creations are by no means in agreement." 202

By the time of Brown, the courts had already advanced a psychological argument to strengthen conclusions of constitutional harm, which had clarified that understanding:

To separate [school children] from others of similar age and qualifications solely because of their race generated a feeling of inferiority as to their status in the community that may affect their hearts and minds in a way unlikely ever to be undone. ${ }^{203}$

Michael Heise discussed the argument leading the court's decision, favorably referencing

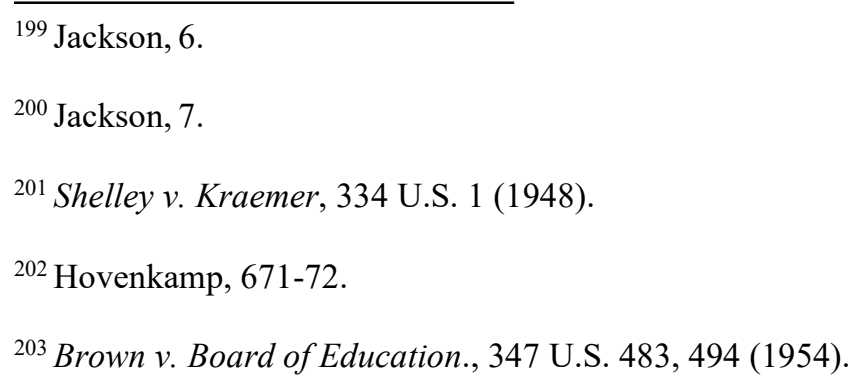


an earlier lower court finding in Belton v. Gebhart (1952) that linked state-sanctioned segregation with psychological harm. In 1954, Heise suggested Warren sought to push the psychological argument further by framing it in the social science research of the prior twenty years with the inclusion of footnote $11 .^{204}$

Though Heise supported Warren's use of footnote 11 as the main instrument, he suggested footnote 11 was not Warren's intent. Instead, Warren used the fourteenth amendment as the lever to sway his colleagues. ${ }^{205}$ In the 1948 case of Shelley $v$. Kraemer, ${ }^{206}$ social science evidence was brought by the NAACP and cited for the ruling to strike down racially restrictive covenants. In the 1950 Sweatt $v$. Painter decision, the work of anthropologist Robert Redfield refuted African Americans as inherently inferior in a case involving admission to a Texas law school. ${ }^{207}$ While the appearance of social science research in court battles, as seen in footnote 11 , was not new in the struggle for civil rights, its appearance in Brown was decisive. Today, we accept and understand that social sciences have and continues to be a significant component in civil rights, as has been the case since the nineteenth century. Names such as Boaz, Herskovits, Frazier, and Myrdal are synonymous with the social sciences and the CRM.

\section{First Traces of the Negro Youth Study}

Buried in the archives of the ACE is a file on the National Advisory Committee on Education and the work of its Committee on Negro Education from 1927-1930. One

\footnotetext{
${ }^{204}$ Michael Heise, "Brown v. Board of Education, Footnote 11, and Multidisciplinary," Cornell Law Review 90, n. 2: 293.

${ }^{205}$ Heise, 314-315.

${ }^{206}$ Shelley v. Kraemer, 334 U.S. 1 (1950).

${ }^{207}$ Heise, 316.
} 
of the first documents in the files housed at Stanford University's Hoover Library is a letter from December 1929 to President Mordecai Johnson of Howard University requesting his presence at a conference on the subject of Negro education and its relationship with the Federal government for Land Grant Colleges and Agricultural Extension. ${ }^{208}$ On January 14, 1930, the National Advisory Committee on Education held a conference on Negro Education. From that meeting, the ACE archives contain a threepage synopsis of the meeting that appears to have been a document for public consumption. ${ }^{209}$ As had been requested back in Mordecai Johnson's letter of 1929, the meeting kept to the economic theme of how to move the federal government to fund the Negro Land Grant and Agricultural Extensions equitably. In 1930, no one talked beyond economics and stayed within the boundaries of the public order concerning Negroes.

The investigations of the NYS aimed to shed light on the question of how best to educate and socialize African American youth to ensure they would not become disenchanted with American mores and democracy. The concerns on the condition of African Americans in the Great Depressing appeared particularly urgent during the years spanning 1935-1944, when fears that African American youth's economic dislocation, joined to their existing marginalization, could quickly turn into radical behavior. Although the Great Depression devastated parts of the nation and its many ethnic and racial communities, it hit especially hard in the African American community.

\footnotetext{
208 "Letter from C.R. Mann to Mordecai Johnson, 30 December 1929" "National Advisory Committee on Education," ACE Papers, Box 57, Folder National Advisory Committee on Education Committee on Negro Education.

209 "Letter from C.R. Mann to Mordecai Johnson, 30 December 1929" "National Advisory Committee on Education," ACE Papers, Box 57, Folder National Advisory Committee on Education Committee on Negro Education.
} 
In a folder labeled "Citizen Conference on Crisis in Education 1932" is an early document demonstrating the first discussions on the educational problems generated by the Great Depression. This "Declaration of Policy" listed forty statements from a “conference concerned with one aspect of the 'educational problem' - the adjustment of school costs to long-term economic conditions with no damage to the child." The document mentioned addressing concerns over African Americans and the first structural foundations of the $\mathrm{NYS}^{210}$ (see Appendix F). The document continued to specify the crisis and concerns arising out of the growing problems of a depression that could go on for some time. Directly relevant here is point 38 :

The Conference notes the critical condition of certain underprivileged groups, particularly the Negroes, and the necessity for special solicitude with regard to them. It is evident that further diminution of educational facilities of this group would handicap them far in excess of the handicaps placed upon other children, and would hazard the possibilities of Negroes participation in our future society with a degree of efficiency commensurate with the demands. The attention of the country, therefore, is called to the fact that serious consideration should be given the past and present unequal educational opportunities before attempting any further retrenchments. ${ }^{211}$

By late 1931, the financial situation concerning funding America's K-20 system had begun to concern educators. In particular, the Citizens' Conference on the Emergency in School Finance under the sponsorship of the ACE's Committee on Problems and Plans came together in Washington, D.C. to assess and address a worsening situation during a two-day meeting from January 5 to 6,1932 . In the ACE archives is an overview of the agenda and summary of the conference. Titled "Statement of the Current Situation" and

210 "Citizens Conference of the Crisis in Education: Declaration of Policy," ACE papers, Box 78, Folder Citizens Conference on Crisis in Education 1932, 1.

211 "Citizens Conference of the Crisis in Education: Declaration of Policy," ACE papers, Box 78, Folder Citizens Conference on Crisis in Education 1932, 5. 
prepared by the Office of Action and the Research Division of the National Education

Association, it summarizes:

I. The Increased Demand for School Services

II. Decreased Financial Resources

III. Educational Adjustments Effected in Attemptsto Reconcile Increased Demand with Decreased Resources. ${ }^{212}$

The report was a collection of local school systems from around the country. Its reporting provides insight into the trajectory of the ACE's efforts as the Depression worsened.

As befits a report on school finances, the section on "Fiscal Factors" opens quickly on local taxation and the delinquency rate for collecting those taxes. From 19301932, the state of Michigan reported its delinquency rate moved from 5 to 37 percent. In Kansas, its delinquency rated moved from 5 to 26 percent. South Dakota had a 25 percent delinquency rate by 1932 . Added to the concerns over taxes was the concern of the number and rate of bank failures noted in the reports. In 1930, 1345 banks failed; in 1931, 2296 failed. ${ }^{213}$ A report from New Jersey was indicative of the period:

Our school employees have been paid entirely in script since December 15, and this will continue until July $1^{\text {st }}$ at least. This is caused by the fact that (a) four of our six local banks closed in December, (b) our funds were in those banks, (c) municipal paper is non-marketable, (d) taxes are 40 percent unpaid due (1) the bank situation, (2) the fact that this is a summer resort which had a poor season last year. ${ }^{214}$

However, some states such as Massachusetts, Kentucky, and Vermont reported little

\footnotetext{
212 "Statement of the Current Situation, January 5-6, 1932" ACE Papers, Box 44, Folder: Citizens Conference on the Crisis in Education, Washington, D.C., 1.

213 "Statement of the Current Situation January 5-6, 1932," ACE Papers, Box 44, Folder: Citizens Conference on the Crisis in Education, Washington, D.C., 11-12.

214 "Statement of the Current Situation January 5-6, 1932," ACE Papers, Box 44, Folder: Citizens Conference on the Crisis in Education, Washington, D.C., 13.
} 
increase in the tax delinquency rate. ${ }^{215}$ Across the country, this was not the norm, and taxation was a primary concern. However, when asking the question who was concerned, the document suggests that it was not the school administrators or school boards.

In the next section of the report, the schools' superintendents had their moment, and though much of the earlier report was neutral to pessimistic, some school leaders reported that Depression hysteria or "Depression talk" was responsible for school reductions rather than a lack of money. The report called for school officials to hold off on retrenchment and refrain from cuts to their schools when it is to "cut down with the Joneses. ${ }^{.216}$ Some examples:

Our entire country and city people have gone panicky. Tennessee School support has been relatively low here, even in good times. The community is relatively well-to-do for this section of the country. Hysteria, rather than necessity, is responsible chiefly for present reductions. The school board is helpless in the face of community demands. Idaho

Our schools are in excellent condition. Our only reason for cutting salaries would be because everyone is talking about "Depression." So far, we have weathered the storm. $\underline{\text { Illinois }}^{217}$

Before concluding the report, the last section of the document discussed the "lack of public confidence." The report saw the gravest of all conditions and the weakening of faith in education as lack of public confidence in education had marked America for the last one hundred years. Again, the statements of the superintendents are informative:

\footnotetext{
215 "Statement of the Current Situation, January 5-6, 1932," ACE Papers, Box 44, Folder: Citizens Conference on the Crisis in Education, Washington, D.C, 19.

216 "Statement of the Current Situation, January 5-6, 1932," ACE Papers, Box 44, Folder: Citizens Conference on the Crisis in Education, Washington, D.C., 27.

217 "Statement of the Current Situation, January 5-6, 1932," ACE Papers, Box 44, Folder: Citizens Conference on the Crisis in Education, Washington, D.C., 28.
} 
The general attitude is without regard to the material injury that may come in the schools. Every effort possible is being made by school people and their friend to counteract the trend. Illinois.

Through the entire state there is an ugly attitude toward public affairs. People sometimes act as they feel that everyone in the public service is a grafter or leech. Mississippi.

The outlook is dark, and the trend is downward in financing education. The demand is to reduce salaries by at least $25 \%$. Oklahoma. $^{218}$

\section{To What Noble End Do We Work? Growing Concerns about "The Negro}

\section{Problem"219}

Why did an intense interest in the welfare of America youth come forward in 1935? The roots of concern began with the realization, by early 1932, that the Depression had set in and might be getting worse. The first paragraph of the The National Advisory Committee on Education's report, "Statement of the Current Situation January 5-6, 1932," indicates the tone of the times seen later in the decade:

The foregoing rapid survey of the factors associated with our causing school fund retrenchments is sufficient to indicate that the support of education has been made part of the general unrest and maladjustment of the times. ${ }^{220}$

The National Advisory Committee on Education articulated a more concise concern regarding African Americans' situation in 1920: there were nineteen thousand

\footnotetext{
218 "Statement of the Current Situation," Folder: Citizens Conference on the Crisis in Education, Washington, D.C., Box 44, January 5-6, 1932, 29. The terms “The Negro Problem" and "The Jewish Problem" were statements of derision and calls for action to the power elites and racists, both in $19^{\text {th }}$ and $20^{\text {th }}$ centuries Europe as well as the United States.
}

Historically, these phrases were also used by both Jews and African Americans as calls to ameliorate the social-economic conditions that were oppressing them. In particular, the quoted phrase, when used by African Americans, "The Negro Problem," was a list of economic, social, and political hardships that African Americans were going to challenge and overcome. This phrase and usage were already in vogue with Du Bois in his early writings.

\footnotetext{
219 "Statement of the Current Situation January 5-6, 1932," ACE Papers, Box 44, Folder: Citizens Conference on the Crisis in Education, Washington, D.C., 30.

220 "Statement of the Current Situation, January 5-6, 1932," ACE Papers, Box 44, Folder: Citizens Conference on the Crisis in Education, Washington, D.C., 29.
} 
Negroes in secondary schools in the South. In 1930, there were 96,000, a number increasing rapidly. The number of Negroes prepared for college was also rapidly increasing, but relatively few found acceptance in state schools. When looking at African American churches, there were 47,000 of them in the United States but little chance for graduate training in the ministries. No Southern state system of higher education offered any chance for training African American physicians, dentists, lawyers, nurses, or engineers. The only exception was Howard University, which was federally supported. Howard and newly developing schools, however, could not shoulder the demands placed upon them. ${ }^{221}$

The committee noted the Southern states had become "friendlier" toward the growing situation with African American higher education. While Whites had trouble covering their schools' expenses, African Americans needed Whites to press their case in White local communities. Overall, it was private philanthropy that helped African Americans with their "upward struggle." 222 In the final paragraph, it was the fiscal failings that drove the committee's work:

The Negro is having trouble getting a foothold in commerce and industry. He is better fitted for farming provided farming is a mode of living, not a job. At present foreign immigrants make farming pay down South while we native Americans "are fussing because someone does not give us a job.",223

\footnotetext{
${ }^{221}$ Circular to National Advisory Committee on Education: Conference on Negro Education, Jan 14, 1930," ACE Papers, Box 57, Folder National Advisory Committee on Education, Committee on Negro Education, 4.

${ }^{222}$ Circular to National Advisory Committee on Education: Conference on Negro Education, Jan 14, 1930," ACE Papers, Box 57, Folder National Advisory Committee on Education, Committee on Negro Education, 5 .

${ }^{223}$ Circular to National Advisory Committee on Education: Conference on Negro Education, Jan 14, 1930," ACE Papers, Box 57, Folder National Advisory Committee on Education, Committee on Negro Education, 6.
} 
In the folder was the basis for much of the work the NYS and ACE entered into as the Great Depression progressed.

\section{Asking Questions is the First Step to Finding Solutions: The Negro}

\section{Youth Study Begins}

As pressure from the conditions exacerbated by the Depression mounted, documents before 1937 demonstrate that momentum was building to bring a significant study into action to ameliorate the worsening conditions of African American youth. Before 1937, this proposal was very close to what would be created and implemented.

The statement of the problem makes clear what the NYS aimed to do:

Negro youth share with all American youth the problem of becoming adjusted in family and other primary group relations, of achieving success in school work and security in economic pursuits, maintaining health, finding a balance between work and play, of assuming responsibility and of acquiring prestige in the social organization of the community, and of working for a personal philosophy that guides their development and provide security in this time of crisis. However, in making their adjustment sot these and similar problems, Negro youth are often influenced by a factor not common to all, namely, their minority racial status in a predominately White society. The complication which this factor brings in to the personality development of Negro youth constitutes the general problem of this study. Stated in question form, it appears as follows: WHAT EFFECTS DOES THEIR MINORITY RACIAL STATUS HAVE ON THE PERSONALITY DEVELOPMENT OF NEGRO YOUTH. ${ }^{224}$

As the NYS readied for implementation, there was building excitement with many offer letters of professionals wanting to participate in a support capacity. Statistician Aaron Paul asked Frazier if he could be a part of the NYS study; he was willing to work for free during his annual vacation. This offer was in response to a request Frazier had

224 “A Proposed study of Negro Youth Recommended to the American Youth Commission," Frazier Papers, Box 131-40, Folder 14. 
made in a recent visit to Frankfort, KY where Paul worked for the Kentucky Department of Welfare. ${ }^{225}$ T. Edward Davis of "The National Education Outlook Among Negroes" in Washington, D.C. also wanted to participate. Davis sent a note to Frazier asking to be part of the NYS. Davis had previously worked with Frazier and offered to help with the statistical phase of the project and collecting newspaper clippings. The offer to Frazier seemed warmly sent. ${ }^{226}$

\section{Codifying the Message: President Franklin Roosevelt's Support for Ending Social Inequalities}

For the Roosevelt administration and the nation, the youth unemployment problem was troublesome. When considering Maslow's hierarchy of needs articulated in 1943 in the shadow of the Depression, readily available food, clothing, and shelter were no longer accessible as they had been to the youth of earlier years, an issue of great concern to local, state, and federal governments. ${ }^{227}$ Perhaps the hardest blow to America's youth was unemployment. In 1937, 18.5 percent of the total unemployed were in the fifteen to nineteen age group, which represented only 8.3 percent of all workers. The next age bracket, twenty to twenty-four, composed 14.8 percent of the labor force and 19.2 percent of the unemployed. By the summer of 1940, there were over four million unemployed youths in America, who accounted for one-third of all unemployed. ${ }^{228}$

\footnotetext{
225 “Aaron Paul to Frazier,” Frazier Papers, Box 131-40, Folder 10.

226 “T. Edward Davis to Frazier,” Frazier Papers, Box 131-40, Folder 10.

${ }^{227}$ Wecter, 24, 107, and 296.

${ }^{228}$ Wecter, 193-194.
} 
Some relief came with President Roosevelt's Executive Order No. 8802, dated

June 25,1941 . That order stated that the in the United States that there shall be no discrimination in the employment in defense industries or government because of race, creed, color, or national origin. The order created a federal Committee on Fair Employment Practice. Despite the efforts of the President and the practices of governmental committees, the report still stated:

Negro people generally are still deeply discouraged over the situation because the current expansion of employment so far has seemed to confirm their previous disadvantages more than relive them.... In quantitative terms, the problem of racial discrimination in employment is so significant that much more than a toke beginning secured before the arrival of cure. ${ }^{229}$

Homer P. Rainey was the director of the AYC, assisted by Robert Sutherland who operated with the underlying assumption that the needs of African American youth were different. The two operational rationales were: (a) there were problems incident to the minority status of African Americans; and (b) since African American youth lived in abnormal environments, remedial measures based upon American youth would be difficult to near impossible. ${ }^{230}$ Immediately, African American behavioral scientists expressed concerns that they should be the ones to direct the studies. The most active were Ira De Augustine Reid, Allison Davis, E. Franklin Frazier, and Charles S. Johnson, who all became involved in the study. ${ }^{231}$

\footnotetext{
${ }^{229}$ Youth and the Future: The General Report of the American Youth Commission, American Council of Education, Washington, D.C., 1942, 150-151.

${ }^{230}$ Stanley H. Smith, "Sociological Research and Fisk University: A Case Study," in Black Sociologists: Historical and Contemporary Perspectives, eds. James E. Blackwell and Morris Janowitz (Chicago: University of Chicago Press, 1974), 176-177.

231 "The Proposal of a Special Study on Negro Youth," Johnson Papers, Fisk University Library Archives, Box 16, Folder 8.
} 


\section{Transitioning Efforts from Rhetoric to Reality: Negro Youth Study in Action}

In the period 1938-1941, the NYS published four major works (American

\section{Children of Cast, Negro Youth at the Crossways, Color and Personality, and Southern}

Rural Negro Youth), along with four lesser studies confirmed the findings of the central studies:

- E. Franklin Frazier's brief volume on the Harlem community in New York City

- J. Howell Atwood's summary about Negro Youth in Galesburg, Illinois

- Donald Wyatt's organizing data on Greensboro, North Carolina

- Joseph A. Pierce's work with the Colored Division of the National Youth Administration in Atlanta, Georgia

The NYS concluded its work with a summary of the field studies in 1940 by Robert L.

Sutherland. ${ }^{232}$ In the report, Sutherland reported that various directors of the project were using different methods in approaching the common problem of personifying development of Negro youth. The principal research techniques were:

- Ecological analysis,

- Cultural studies of community values and relationships, and

- Case studies of individuals, family and youth groups.

For the case studies, some of the various methods employed included:

- Free associational interviewing within the community,

- Intensive psychoanalytic interviewing, and

- Guided interviews. ${ }^{23}$

As the NYS progressed in its wor4k, in a letter dated February $15^{\text {th }}, 1940$,

Sutherland wrote to Frazier asking him for suggestions in preparing a comprehensive

\footnotetext{
232 "Report of Progress on the Negro Youth Study of the American Youth Commission," Frazier Papers, Box 131-25, Folder 5.

233 "Sutherland to Advisory Committee and Consultants of the NYS," Frazier Papers, Box 131-25, Folder 6.
} 
plan to announce the publication of the reports of the NYS. Sutherland asked four questions of Frazier:

1. What organizations might be willing to cooperate by making their membership lists available and how should we get I touch with these groups?

2. Do you have access to, or do you know of appropriate mailing lists?

3. As a result of personal contact or correspondence have you any list of people who should be notified of publications?

4. What publicity outlets are responsible, including magazines, journals, bulletins, that might review books? Do you write for any of these? ${ }^{234}$

Sutherland closed by stating the NYS had made a real contribution and he wanted to get it into the "hands of those in key places." In a letter dated June $18^{\text {th }}, 1940$, Sutherland wrote to Frazier with an opportunity to be part of the Gallop Poll for a nation-wide survey of opinions on race relations. Sutherland told Frazier that Gallop intended to ask more than three thousand African Americans and Whites questions on race with the possibility that this sample would double. Gallop intended to ask Whites and Negroes "how it feels to be a Negro" and about their attitudes toward Whites. Sutherland asked Frazier for suggestions on what he would like to see in the survey. ${ }^{235}$

Overhanging the entire NYS were the ever-present realities generated by the Great Depression. As the project examined the "waste" of human resources, its context was the growing employment inequality between African American and White workersas the United States became the arsenal for democracy and pulled itself out of the Great Depression. In the early stages of WWII, African American unemployment was grimwith just 3 percent of all workers in the defense industry. Even those companies that hired African American workers only allowed them to work as manual laborers. With such low

234 “Sutherland to E. Franklin Frazier," Frazier Papers, Box 131-25, Folder 6.

235 “Sutherland to E. Franklin Frazier,” Frazier Papers, Box 131-25, Folder 5. 
labor participation rates, African American participation in relief programs remained high. When considering that most of the public relief programs initiated in the New Deal fell afoul of the Supreme Court and were short-lived by definition, African Americans faced the risk of even greater unemployment unless these trends changed. ${ }^{236}$

\section{Surveying the Fruits of the Harvest: Negro Youth Study Produced Texts}

The AYC began its work by commencing an extensive literature search to learn what research had been done to date on American youth; the same held true for the NYS. To that end, the ACE in 1940 published In Minor Key which characterized the work of the NYS. Minor Key was a collection of public and private information on the condition of African American youth in America, reporting on the research being developed for implementation in the early 1940s. To understand the NYS' direction, the chapter titles of In Minor Key are illustrative:

1. Life and Death: Children are Born...some grow older...the group gets thinner in the middle... a few continue a kind of hobbling march

2. No Place Like Home: Of parcels and estates, cabins, and castles

3. Literacy and Learning: Of learning late in deceased beggary

4. Living off the Soil: The Negro farmer's in a mess

5. Racial Competition for Jobs: Othello's occupation's gone

6. The Negro Professional: White collar and "best people"

7. Relief and Recovery: They toil not and neither do they spin

8. Let Us Pray: The church sees its ancient verities questioned, its paradise lost; it "looks" right and "eases" left

9. The Evil Men Do: Of crimes and arrests, prosecutions and convictions, mobs, and lynching

10. The Law: We must not make a scarecrow of the law

11. Planning for Survivors: For work does good when reason fails ${ }^{237}$

\footnotetext{
${ }^{236}$ Touré F. Reed, Not Alms but Opportunity: Urban League and The Politics of Racial Uplift, 1910-1950, (Chapel Hill, NC: University of North Carolina Press, 2008), 139-140.

${ }^{237}$ Ira De Augustine Reid, In Minor Key: Negro Youth in Story and Fact (Washington, D.C.: American Council on Education, 1940), Contents.
} 


\section{No Place Like Home (chapter 2)}

The social and cultural problems that African American youth faced were described as:

Negro youth emerged from home environments filled with both social and cultural problems. Their families in the main do not have that long, unbroken set of rules and sanctions to keep them intact which characterizes some older White populations. Centuries of slavery have left a deep imprint. Negro homes, all in all, are dreary dwellings, on neglected streets without pavements, littered by accumulated wastes, in the oldest residential sections of the city.

Generalization of the housing conditions of the mass of the Negro population is difficult since the types of segregated areas Negroes live in are limited only by the ingenuity of town planners and the sporadic city growth. But a summary of the chief characteristics might include:

- Discriminatory limitation of residential areas open to Negroes

- Enforce association of all types and classes of Negro individuals

- The tendency of municipal neglect of section abandon to Negro residents

- Lack of strict enforcement of sanitary regulations

- The disturbing indifference of Negroes themselves to these unfavorable conditions - which is, of course, in lager part because conditions are tolerated by the public authorities, the landlords, and the community at large. ${ }^{238}$

Social and cultural factors also conditioned life within Negro homes:

- Untimely death, desertion, and illegitimacy, and other abnormalities related to health, crime, and morals appear with startling frequency in the Negro family group

- The average Negro home, urban or rural, is without many of the fundamental necessities for a minimum standard of economic and cultural decency

- The presence of poverty may be reflected in the family disorganizationlaxity in sex and intrafamily relationships, improper are of children, and in parent working away from home

- Add to these conditions the problem of race discrimination and there is little reason to wonder at the pessimistic outlook of many youths ${ }^{239}$

\footnotetext{
${ }^{238}$ Reid, In Minor Key, 25-27.

${ }^{239}$ Reid, In Minor Key, 28-31.
} 


\section{Literacy and Learning (chapter 3)}

The major problem in educating the negro youth today is one that is closely allied with the separate school's programs of the Southern States - the problem of adequate financing:

- In 11 southern states the Negro youth receives $35 \%$ of the amount to which he is entitled based on an equal distribution of public funds

- High school teachers receive less than $47 \%$ of the salary received by White teachers.... Annual expenditures (1930) in the South of $\$ 43.31$ for White children and $\$ 12.57$ for Negro children. In 1930 Negro youth received almost one-fourth of the amount spent on White youth in the 'South and one-eighth of the amount spent on the average for in the country as a whole. ${ }^{240}$

\section{The Law (chapter 10)}

While the Negro strives to improve the conditions under which he lives, he increasingly finds his progress hindered by the letter, sometimes by the spirits, or often by the interpretation of the law-federal, state, or municipal. Many of the laws in the United States are deliberately designed to either abrogate and restrict the right of Negroes, or to establish and protect the rights of the Negroes. The examination reveals the limitations of the franchise, the unequal distribution of funds for public education, the denial of social, civic, and personal rights supposedly guaranteed by the Constitution and laws - all these notorious and menacing commentaries are what is meant to be a Negro in the United States. ${ }^{241}$

The self-stated purpose of the bibliography was:

American Youth: An Annotated Bibliography takes its place in the series of preliminary reports prepared by the staff of the Commission. With its 2,500 annotated entries, representing recent writings in a score of major areas of human knowledge, it is the most comprehensive survey and digest of literature of youth problems now available. ${ }^{242}$

In a hundred cities and a thousand towns, and in uncounted rural communities in three thousand counties, there are citizens whose social conscience and parental interest give them a high stake in the welfare of youth....This is a generalized

\footnotetext{
${ }^{240}$ Reid, In Minor Key, 28.

${ }^{241}$ Reid, In Minor Key, 99-104.

${ }^{242}$ Louise Arnold Menefee and M.M. Chambers, American Youth: An Annotated Bibliography (Washington, DC: American Council on Education, 1938), v.
} 
layman's interest, impatient with technicalities but eager to see all around a problem and seize upon the upshot of it. ${ }^{243}$

Contents of the bibliography were subtitled:

I. The Problems of Modern Youth

II. Attitudes of Youth

III. Youth in the Depression: Unemployment and Relief

IV. Employment and Vocational Adjustment

V. Education

VI. Health

VII. Child Welfare and Child Labor

VIII. Adolescence

IX. Family Life and Housing

X. Leisure and Recreation

XI. Citizenship, Character, and Religion

XII. Delinquency and Social Maladjustment

XIII. Governmental Youth-Serving Agencies

XIV. Non-Governmental Youth-Serving Organizations

XV. Social Organization, Research, and Surveys

XVI. Rural Youth

XVII. Negro Youth

XVIII. Youth in Other Countries

XIX. Bibliographies ${ }^{244}$

In a review of the preparatory work ahead of creating the final volumes of NYS, Sutherland noted the special attention given to variant influences at the different social levels within the African American groups and in the function of such factors as family position, education, occupational status, physical appearance, and so forth in developing the social world of the boy or girl. ${ }^{245}$ Intensive study of patterns of accommodation and conflict that characterize the personality reactions of youth and the social roles which they play became the central objective of the study. The research problem was stated as:

\footnotetext{
${ }^{243}$ Menefee and Chambers, $\mathrm{x}$.

${ }^{244}$ Menefee and Chambers, vii.

245 "Summary of Statement Robert L. Sutherland Before American Youth Commission Section, Meeting 8 May 1937: Study of Negro Youth,” Folder American Youth Commission Negro Youth Study, Box 181.
} 
"What effects, if any, does their status as members of a minority racial group have upon the personality development of Negro youth?"246

As an academic project, the NYS generated a constant stream of peer review and discussion on methods and efficacy. In a review of Warner's manuscript, Sutherland offered a lengthy eight-page review with many suggested edits. This manuscript, referenced as the Chicago Study, was initially seen as a more systematic approach that the "sociologist and anthropologist would appreciate." Secondly, for Sutherland, Warner's work was more direct in addressing the "central problem" of the study — the function of color, caste, or minority status - than the other studies. Sutherland saw this emphasis on color in Warner's manuscript as a subject that had been neglected in the past and that would make this study of great interest to the lay and learned. ${ }^{247}$

Sutherland's preface encapsulated the issues studied and the position of the researcher as it began:

Interest in the process through which human personalities develop is widespread. Unusual indeed is the individual who does not wish to learn more about the reason why some persons aggressively dominate their environment, while others become timid, clinging-vine personalities, why some strive ambitiously to achieve higher standards, while others are satisfied with decreasingly low levels of accomplishment; and why some react violently against members of alien groups and others are tolerant of people of another color or condition of birth. ${ }^{248}$ The preface gives an overview of a work that was primarily eight case studies of African American adolescents in a quest to answer the question of what it means to be born an

\footnotetext{
246 “Summary of Statement, 8 May 1937," ACE Papers, Box 81, Folder: American Youth Commission Negro Youth Study."

247 "Letter from Robert L. Sutherland to Warner, 28 February 1939," ACE Papers, Folder American Youth Commission Negro Youth Study, Box 181.

248 "Sutherland to Mr. Reeves, Memorandum: This is a Copy of my Preface to the Davis-Dollard Volume, Dec 1939,” ACE Papers, Box 181, Folder: American Youth Commission Negro Youth Study.
} 
African American. Also trying to understand the socializing process, Sutherland stated that the authors had come closer to the intimate lives of youth by not divorcing personality traits from the cultural environment in which their youth developed. The NYS researchers wanted to analyze how a growing personality interacts with those rewards, punishments, incentives, and taboos, which form the world experience of children as they move toward adulthood.

The NYS researchers understood that both African American and White children grow in a world of family, clique, and class controls that define their success or failure in life. What is different for the African American child are the caste-like taboos which limit the ceilings of economic and social success, which force him to compensatory satisfactions and set the bounds within his own society to pass its judgments on his success or failure. The title of this first volume was "Children of American Caste." ${ }^{249}$ As this volume was the first of four that would become the significant part of the NYS published works, Sutherland wrote that the AYC early on recognized that employment, housing, and emotional conditions had already been heavily researched and reported. Therefore, the NYS was to deal with the inner world of African American youth. In his review of the Davis-Dollard manuscript, the second of four major texts produced by the NYS, now referenced as a book, Johnson worried that the book would have to survive criticism of those who doubted the validity and adequacy of behavioristic psychology and Freudian theories. Overall, Johnson believed that with his corrections in

\footnotetext{
249 "Sutherland to Mr. Reeves, Memorandum." ACE Papers, Box 181, Folder American Youth Commission Negro Youth Study.
} 
place, the research would throw a "very interesting light on the question of caste and class." 250

Sutherland, in discussing how to best present the four-volume study, offered a compromised solution to suit the more popular presentation camp. The opening chapter would deal with the common fallacies of the African American personality. He wanted to begin his chapter by listing the stereotypical notions such as happy-go-lucky, irresponsible, unintelligent but patient, emotional, and immoral nature to capture the lay reader's attention while giving the reader a point of focus for the study refuting these fallacies while demonstrating the highly differentiated behavior of African American youth. ${ }^{251}$ Sutherland gave a favorable review of the work of the NYS and believed that despite the new method of personality study used, the "built up" reactions in society regarding recognition of class and caste structures would imply the work had been seen favorably by reviewers and lay readers. ${ }^{252}$

In a letter where Sutherland notified Reeves of his thoughts on the Chicago manuscript, Sutherland over and over repeated his concern that this manuscript and the other three be written well, be easily understood, and above all meet the rigors of science. Unlike the Davis-Dollard study, the Chicago Manuscript presented its cases in a fragmentary manner that required the reader to accept the findings on faith instead of

\footnotetext{
250 "Letter Johnson to Reeves, 12 December," ACE Papers, Box 181, Folder: American Youth Commission Negro Youth Study.

251 “Letter from Robert L. Sutherland to Floyd Reeves, 22 November 1939,” ACE Papers, Box 181, Folder: American Youth Commission Negro Youth Study.

252 “Comments of Davis-Dollard Typescript Transmitted by Dr. Sutherland," No Date, Box, ACE Papers, Box 181, Folder: American Youth Commission Negro Youth Study.
} 
through statistics and science. ${ }^{253}$ Sutherland sent a copy of an article he submitted to the North Carolina Journal that Reeves had requested to add to his files. In Sutherland's article, "Cultural Influences in the Education of Negro Youth," ${ }^{254}$ he asked why those working to improve the condition of African Americans encountered arguments that African American youth were not taking full advantage of the opportunities offered to them. He furthered tried to answer the criticism that African American youth were unresponsive to educational activities and lacked occupational ability. As Sutherland believed that the NYS was not specifically directed at the African American educational problem, this paper did not summarize the study. However, Sutherland discussed aspects of cultural and group dynamics of the learning process that offered context to his. ${ }^{255}$ Moving into the classroom, Sutherland described the effects of a compliant child both on the teacher's success and classroom management, acknowledging that the majority of these children come from middle-class families that have imbued in their children the necessity of education. Sutherland suggested most teachers are unaware that these parents "are on her side" by reinforcing the standards of school back in the home. ${ }^{256}$

\footnotetext{
253 "Sutherland to Floyd Reeves, 10 January 1940," ACE Papers, Box 181, Folder: American Youth Commission Negro Youth Study.

254 "Cultural Influences in the Education of Negro Youth," The High School Journal, vol. 23, no. 3, March 1940, p. 122.

255 "Sutherland to Floyd Reeves," ACE Papers, Box 181, Folder: American Youth Commission Negro Youth Study, 1-2.

256 "Sutherland to Floyd Reeves," ACE Papers, Box 181, Folder: American Youth Commission Negro Youth Study, 2-3.
} 


\section{Recognizing Results: How to Situate Documents Produced by the Negro Youth Study}

Sutherland opened his report with a recapitulation of the research question decided in 1937: "What are the Effects, if any, Upon the Personality Development of Negro Youth of their Membership in a Minority Racial Group?" He then launched into an overview of the forthcoming work. That work was the product of two and a half years of labor, including twelve months of field research organized into seven printed and three mimeographed volumes. The first principal volume was In a Minor Key Negro Youth-A Preface in a Story and Fact (1940). Here, Ira De A. Reid prepared a report on how statistical data were collected and presented regarding African American youth. Next was Allison Davis and John Dollard's Children of American Caste: A Study of Personality Development of Negro Youth in the Urban South (1940), the first of four reports based upon field research. This work focused on the problem of what it means to be born and raised as a member of a minority race whose status concerning the majority is regulated by custom, mores, and law. Davis and Dollard used intensive personality analyses from over two hundred African American teenagers about their relationships with White people. Along with the interviews, the researchers spoke with family members, teachers, and friends. In expanding the study's scope beyond individual students, the researchers administered Stanford-Binet and medical exams to the subjects. Sutherland spent some time reporting the effort on including many groups and castes to balance the research. The cases selected were located in African American communities in New Orleans, Natchez, Atlanta, Nashville, and Greensboro. Many thanks were offered to the public school systems that assisted the research. 
The third volume was Frazier's work, Negro Youth at the Crossways (1940). This work came out of African American communities in Washington, D.C. and Louisville, which were taken as representative cities of border states culture. In this study, Frazier used 268 African American youth to relay their experiences in the interracial sphere. Frazier used various social classes. The community was central to this study, with questions of stratification, social movement, social pathology, and interracial relations of the African American community. Further differentiation was done by family, neighborhood, school, church, and employment. This was personified by two complex case studies of a young man and a young woman.

Color and Personality (1941) by W. Lloyd Warner focused on Chicago and gave special attention on the part played by skin color and physical characteristics in the social adjustment of African American youth in Chicago. It also offered interpretations of the total experience of African American personalities. A major portion of the study drew upon a two-year Work Projects Administration analysis of a Negro community in Chicago. That study sampled over 850 men and women arranged by sex, place of birth, and early childhood locations, degree of "negroidness," and social class position in the Chicago African American community. Again, the research question was: what are the typical patterns of adjustment that characterizes these Negro youths' reactions to their minority racial status?

The final study was The Negro Youth in the Rural South (1941) by Charles S. Johnson. Johnson examined community, family, neighborhood group, and individual material secured from a statistical sampling of six rural Southern counties. Johnson conducted an elaborate battery of tests to yield comparable data regarding intelligence 
and various personality traits. The tests concerned social attitudes of African American youth related to color, race, and discrimination. Finally, Johnson compared the results to a tabulation of over six thousand youth equally divided between rural and urban cases.

The published work was an edited volume by Sutherland. ${ }^{257}$ In the forward to the report, the authors placed American youth concerns in the post-War context. ${ }^{258}$ In the introduction, Commission Chairman Owen D. Young gave the overarching purpose of the report: a program based on experience from the past, adjusted to the harsh realities of the present, and adequate for the foreseeable needs of the future. ${ }^{259}$

In 1938, a project was initiated by AYC to test out occupational adjustment community programs in four cities and four rural communities. The AYC carried out the project in eighteen months, ending in the summer of 1939. It was evident to the AYC the employment problem would be almost impossible to alleviate under the economic conditions of the time. The economic realities of the Depression were disrupting the lives of millions of youth. ${ }^{260}$ With the backdrop of the war in Europe, the United States began to mobilize and become the arsenal for democracy. The Commission looked at how to bring youth unemployment down through employment in private industry. In September 1939, the pamphlet A Program of Action for American Youth again sounded the alarm: "The Commission feels obliged to emphasize the fact, whether, in war or peace, any

\footnotetext{
257 "Report of Progress on the Negro Youth Study of the American Youth Commission," approximately late 1939, ACE Papers, Box 181, Folder: American Youth Commission Negro Youth Study.

${ }^{258}$ Youth and the Future, v.

${ }^{259}$ Youth and the Future, ix.

${ }^{260}$ Youth and the Future, xii.
} 
nation interested in self-preservation must see to it that the young have grown into useful citizens." $" 261$

Halfway through the report, in the chapter on "Occupational Adjustment," the report offers a three-page subchapter about racial discrimination called "The Special Problem of Negro Youth.” The report's mission was to offer analysis of the unemployment problem of the day and to offer solutions that would guarantee full employment following the conclusion of WWII. However, African American youth already had a difficult time securing unskilled positions; for them, the issue of racial discrimination was an additional burden compounding their employment difficulties. In spite of the massive industrial expansion in the run-up to the U.S. entry into WWII, African American youth unemployment was still bleak. ${ }^{262}$

\section{Settling Upon Answers: Considering the Contributions of the Negro Youth Study}

What could be done? In the concluding section of, "Youth and the Future," the report described the problem as acute and called for constant attention and assistance from men of good will. The employers and unions held the most significant responsibility and needed to become aware of the obligation to pursue policies of justice. To the schools and public employment offices, they are seen as having a strategic position and thus should make every effort toward securing equal opportunities for African American youth. With one in ten youth being African American at the time, their frustration and bitterness brought an element of weakness to the nation at a time that all were looking to

\footnotetext{
${ }^{261}$ Youth and the Future, xii.

${ }^{262}$ Youth and the Future, 149-150.
} 
be strong. ${ }^{263}$ Addressing the problem with education, the report discussed the fundamental problem as the reliance on local taxes and decline in revenue from falling property values with concomitant school taxes. Compounding this problem were underlying systemic issues in the segregated schools, specifically in the seventeen states where segregated schools were pervasive:

- Markedly shorter terms

- Grossly inferior housing and equipment

- Substantially lower salaries for teachers

- Distinctly inequitable financing as compared to White schools in the same state. ${ }^{264}$

${ }^{263}$ Youth and the Future, 151.

${ }^{264}$ Youth and the Future, 130-131. 


\section{CHAPTER V \\ THE NEGRO YOUTH STUDY: THE DETAILS}

\section{Introduction}

The surveys, organization, and administrative discussions provide an

understanding of how the NYS worked, what was asked, and how it fits into the history

of sociology before Brown and the CRM from the late 1950s to the early 1970s. The

AYC began in 1935 with a concern for "circumstances of the period":

Thousands of youth were roaming the country as destitute youths, high schools in almost every community across the country dealt with sudden increases in enrollment at a time when school taxes often remained unpaid and school budgets slashed. The great fear was what was going to happen to the millions of youth who were not in school and not entering the workforce. ${ }^{265}$

The "emerging" youth problem surfaced with educational institutions that sounded the alarm as they had to deal with the burgeoning problem. The ACE saw this problem as a crisis and formed the AYC with funding from the Rockefeller Foundation's GEB. The AYC had great latitude in addressing and reporting on the youth crisis. ${ }^{266}$ When creating the commission, the ACE made the following statement:

Recent social and economic changes in the United States have given rise to the difficulties in the care and education of young people with which existing institution are quite un prepared to deal adequately. The changes have not only intensified the problems which confront the schools, but have also created an urgent need of protection and further education of millions of youth schools are not now reaching. Without some provisions for basic planning to meet the situation, there is danger that the present situations may constitute a fundamental threat to the national welfare [emphasis added]. ${ }^{267}$

\footnotetext{
${ }^{265}$ Youth and the Future: The General Report of the American Youth Commission, American Council of Education, Washington, DC, 1942, ix.

${ }^{266}$ Youth and the Future, $\mathrm{x}$.

${ }^{267}$ Youth and the Future, $\mathrm{x}$.
} 
The AYC was immediately hampered by the lack of factual information. Its first order of business was to collect research previously done, organize fact-finding conferences, and conduct fieldwork to collect the data necessary to address their concerns. For the authors of Youth and the Future (1942), was that the 1937 work, Youth Tell Their Story, was central to the work of the AYC over its seven-year lifespan. It was the first work that based its conclusions on a large-scale field survey. The conclusion of the study was that there were four million unemployed youth that Census data latter verified. $^{268}$

When faced with the profound shock of such high youth unemployment, the commission members' first thoughts were that the American economy would rebound and that return of the American economic engine would soon ameliorate the situation. While hoping for a miracle of American economic power, the commission believed a thorough study and exploration on the conditions that could ameliorate the situation by changing social "facilities" would smooth the path into and through high school with youth then moving into a job. ${ }^{269}$

A brief account of the first meeting of the commission was given in "Occupations- The Vocational Guidance Magazine" of November 1935. The director of the National Youth Administration participated in the initial meeting of the Youth Commission, which was addressed by Homer Price Rainey, president of Bucknell University, who directed the commission's work. The following is a list of suggestions and recommendations made by Dr. Rainey:

\footnotetext{
${ }^{268}$ Youth and the Future, xi.

${ }^{269}$ Youth and the Future, xi-xii.
} 
1. A comprehensive study of the youth problem should be made and a composite picture of it formulated.

2. The contribution of the many agencies at work in this field should be studied and evaluated.

3. As suggested by the cooperating committee of the American Council of Education, a study of the characteristics of youth should be immediately under- taken.

4. The problems of secondary and general education in rural districts and small towns must be studied, for about two-thirds of all students of high-school age are in schools having an enrollment of 100 or less.

5. The numerous experiments being carried out and should be examined and their tested results recommended to the people of the country. New experiments should be tried wherever it seems desirable and wise to undertake them. ${ }^{270}$

In the synopsis of the January $14^{\text {th }}, 1930$ meeting, the committee supported its contentions by driving statistics, not sociology. The seventeen colleges in the Southern states, covering an area containing ten million people, received $\$ 338,000$ of out the $\$ 13$ million in federal grants tied to the land grant institutions. This equaled one-fortieth out of the total for one-tenth of the U.S. population. In the last sentence of the synopsis, the committee noted, "not one of these seventeen institutions come near the standards maintained or covering the area of service rendered by White colleges."271

Much of this situation stemmed from the passage of the second Morril Act, ${ }^{272}$ which contained no provisions for African American colleges. Although the act stipulated that the states should divide the Morril funds between African American and White

\footnotetext{
270 "Unemployed Youth," Source: Monthly Labor Review 42, no. 1 (January 1936): 74-76. Accessed October 27, 2017. Stable URL: http://www.jstor.org/stable/41814702.

271 "Circular to National Advisory Committee on Education: Conference on Negro Education, Jan 14, 1930," ACE Papers, Box 57, Folder National Advisory Committee on Education, Committee on Negro Education, 19-20.

${ }^{272}$ The Morril Act of 1862 and the Morril Act of 1890 were the basis for the creation of Land Grant Colleges. The Morril Act of 1890 established the foundations for Historical Black Colleges and Universities.
} 
colleges, the White schools received all the funds. African Americans did not ask for the funding to White schools to be reduced. Rather, they asked that funding for African American schools be equitable. ${ }^{273}$ The second Morril Act also stipulated that states should create experimental stations and agricultural extensions. African Americans were denied these opportunities and only participated in them as laborers. The committee relayed the belief that "Negro supervision of Negroes works better. Negros are adept at fooling Whites." 274 The report was replete with these mixed messages.

\section{Edward Franklin Frazier}

In the Frazier Papers was a foundational document laying out the purpose and structure of would become the NYS (see Appendix G). Though the study's structure seemed well thought out, a question arose as to the basic framework for fieldwork. In a letter dated June $9^{\text {th }}, 1937$, Sutherland contacted Frazier as the NYS began to take shape. He introduced the conceptual framework as "some type of study in the general field of the social, economic, and educational problems of Negro youth." Sutherland wanted to visit with Frazier in June to discuss the proposed NYS study. ${ }^{275}$

On December $10^{\text {th }}, 1937$, Sutherland followed up with Frazier since their meeting in the summer of 1937 where Sutherland introduced the concept of the NYS. In this letter, Sutherland informed Frazier that the advisory committee for the NYS had

\footnotetext{
273 "Circular to National Advisory Committee on Education: Conference on Negro Education, Jan 14, 1930," ACE Papers, Box 57, Folder National Advisory Committee on Education, Committee on Negro Education, 18.

274 "Circular to National Advisory Committee on Education: Conference on Negro Education, Jan 14, 1930," ACE Papers, Box 57, Folder National Advisory Committee on Education, Committee on Negro Education, 3. "National Advisory Committee on Education."

275 “Sutherland to E. Franklin Frazier,” Frazier Papers, Box 131-40, Folder 14.
} 
approved the study in line with the discussions they had had in the summer. Sutherland aimed to recruit Frazier to lead the study and to ask Frazier for suggestions to employ staff. Sutherland was already planning case study methods, application of statistical methods to the study of attitudes, and ethnographic description of cultural patterns.

On December $14^{\text {th }}, 1937$, Frazier warned Sutherland concerning the organizational structure of the NYS as being "three or four co-directors, each heading up one phase of the study." He was worried that this decentralized structure was not an attempt to distribute the project as "research patronage," as this, he believed, would make the study worthless as he had seen happen before. Frazier agreed to work half-time during the academic term and full-time in the summer. ${ }^{276}$

Finally, in a follow-up to the letter dated December $14^{\text {th }}$, Sutherland was a bit confused as Frazier seemingly had questioned the decentralized nature of the study and suggested it would be best for it to be centralized. Sutherland was under the impression that Frazier had agreed to a decentralized structure in the previous summer's meeting. Sutherland then asked Frazier if he would "not find it pleasant to work with other scholars, particularly Negro schools, or to work with the personnel of the Advisory Committee." In the next letter in this exchange, December $21^{\text {st }}, 1937$, Frazier returned to his original belief that a decentralized, multiregional study would be the best approach. He then volunteered to lead the urban track of the NYS study. ${ }^{277}$

\section{Preparing the Study}

In the lead up to the publication of the NYS, numerous documents suggested the

\footnotetext{
276 "Frazier to Sutherland," Frazier Papers, Box 131-40, Folder 14.

277 “Frazier to Sutherland," Frazier Papers, Box 131-40, Folder 14.
} 
researchers wanted to ensure the study would demonstrate patterns of accommodation and conflict that characterized the personality reactions of youth and the social roles central to the study. The research problem was stated as: "What effects, if any, does their status as members of a minority racial group have upon the personality development of Negro youth?"278

In a review of the preparatory work to create the final volumes of the research, Sutherland gave particular attention to influences at different social levels within the Negro group and to the function of such factors as family position, education, occupational status, and physical appearance in developing the social world of the child. The review process was exacting and is clearly seen in Sutherland's eight-page review of Warner's work with many suggested edits. This manuscript, referenced as the Chicago Study, was initially seen as a more systematic approach that the "sociologist and anthropologist would appreciate. Secondly, Sutherland believed the NYS was more direct in trying to understand the "central problem" of the study: the function of color, caste, or minority status than the other studies. More important for Sutherland was the NYS emphasis on color, which did not ignore the function of other conditioning forces. Sutherland thought this emphasis on color, a subject Sutherland said had been neglected in the past, would make the Chicago Study of great interest to the lay and learned. ${ }^{279}$ Sutherland's preface encapsulates the issues studied and the position of the researcher:

278 “Summary of Statement, 8 May 1937," ACE Papers, Box 181, Folder American Youth Commission Negro Youth Study.

279 “Letter from Robert L. Sutherland to Warner, 28 February 1939," ACE Papers, Box 181, Folder American Youth Commission Negro Youth Study. 
Unusual indeed is the individual who does not wish to learn more about the reason why some persons aggressively dominate their environment, while others become timid, clinging-vine personalities, why some strive ambitiously to achieve higher standards, while others are satisfied with decreasingly low levels of accomplishment; and why some react violently against members of alien groups and others are tolerant of people of another color or condition of birth. ${ }^{280}$

The preface overviews the work as comprised of eight case studies of African American adolescents in a quest to answer the question of what is means to be born an African American. Also trying to understand the socializing process, Sutherland stated that the authors had come closer to the intimate lives of youth by not divorcing personality traits from the cultural environment in which the youth developed. The researchers wanted to analyze how a growing personality interacted with the rewards, punishments, incentives, and taboos, which formed the world experienced by children as they moved toward adulthood.

The authors understood that both African American and White children grow in a world of family, clique, and class controls that define their success or failure in life. What is different for the African American child are the caste-like taboos which limit the ceilings of economic and social success that force him to compensatory satisfactions and set the bounds within his own society and pass judgments on his success or failure. The title of this first volume was Children of American Caste (1940). ${ }^{281}$ As this volume was the first of four that would comprise the major part of the published work, Sutherland wrote the AYC early on recognized employment, housing, and emotional conditions had

\footnotetext{
280 "Sutherland to Mr. Reeves, Memorandum, 28 Dec 1939," ACE Papers, Box 181, Folder American Youth Commission Negro Youth Study.

281 "Sutherland to Mr. Reeves, Memorandum, 28 Dec 1939," ACE Papers, Box 181, Folder American Youth Commission Negro Youth Study.
} 
already been heavily researched and reported. Therefore, this study dealt with the inner world of African American youth.

\section{Academic Review and Discussions}

As the various manuscripts neared completion, the researchers corresponded with Sutherland and each other over the findings and how to report their work. In the NYS, the researchers were exact, critiquing with vigor and civility, acting well in receiving the criticism and generally scholarly in the application of the review process. Later in the letter, Johnson worried the book would have to survive the criticism of those who doubted the validity and adequacy of behavioristic psychology and Freudian theories. Overall, Johnson believed that with his corrections in place, the research would throw a "very interesting light on the question of caste and class."282

Sutherland, in discussing how to best present the four-study volume, offered a solution to suit the more popular presentation camp. The opening chapter would deal with the common fallacies of the African American personality. He wanted to begin his chapter by listing stereotypical notions such as happy-go-lucky, irresponsible, unintelligent but patient, emotional, and immoral nature to capture the lay reader's attention while giving the reader a point of focus for the study, refuting the fallacies while demonstrating the highly differentiated behavior of African American youth. ${ }^{283}$

Sutherland gave a favorable review and believed that in spite of the new method of personality study used, the "built up" reactions in society regarding the recognition of

\footnotetext{
282 “Letter Johnson to Reeves, 12 December," ACE Papers, Box 181, Folder American Youth Commission Negro Youth Study.

283 “Letter from Robert L. Sutherland to Floyd Reeves, 22 November 1939," ACE Papers, Box 181, Folder American Youth Commission Negro Youth Study.
} 
class and caste structures would mean work had been seen by others favorably. ${ }^{284}$ In the Frazier Papers is a three-page compilation of criticism requested from reviewers. The criticism is sharp with just one very short positive response:

Having gone over the material on the Negro Youth Study of the AYC which you sent me, I am most impressed with the fact that many of the investigators are going to the problem with highly preconceived ideas of it. I cannot believe that this represent a scientific attitude toward the problem.

Why all the secrecy? Why does someone not state specifically what he desires to find out and how he proposes to get the information?... Is the excess wordiness and absence of concrete formulation a smoke screen to conceal an "eight-ball" some place in the picture?

I was surprised to note the variations in the procedures employed in the several areas... I think it would be very desirable, if not necessary, to bring the facts of all the areas together in a single summary statement. This will most likely be impossible as the studies are now organized.

I gathered in reading one of the sections that some of the directors are anticipating several volumes of data to come out of the study. Personally, I think this would be unfortunate. It would obviously mean the production of a "Source Book" or encyclopedia; which means again that we would have a voluminous collection of undigested data which would defeat the purpose of the study.

The methods employed in the different areas appear to be so disparate as to prevent any very close comparison of the data from different areas. ${ }^{285}$

In a letter where Sutherland notified Reeves of his thoughts on the Chicago

manuscript, Sutherland repeated his concern that this manuscript and the other three be written well, be easily understood, and above all meet the rigors of science. Unlike the Davis-Dollard study, this study presented its cases in a fragmentary manner that required the reader to accept the findings on face value instead of through statistics and science. $^{286}$

\footnotetext{
284 “Comments of Davis-Dollard Typescript Transmitted by Dr. Sutherland," No Date, ACE Papers, Box 181, Folder American Youth Commission Negro Youth Study.

285 “Criticism of Study,” Frazier Papers, Box 131-106, Folder 3.
} 


\section{Manuscript Preparation}

Moving toward completion, another major step in the process was the final discussion before the manuscripts went to press. The researchers continued with the civil discourse while fine-tuning what was to be published. This was also the moment to finalize the studies and publish the questionnaires and instruments. An understanding of what they looked like gave the researchers the clearest understanding the power the NYS would have when the data were collected. From the questions asked, it is clear what they saw as the problem and what African Americans experienced under Jim Crow and the pressures of the Great Depression.

Sutherland sent a copy of an article he submitted to the North Carolina Journal that Reeves had requested to add to his files. In Sutherland's article, titled "Cultural Influences in the Education of Negro Youth," he began by asking why those working to improve the condition of African Americans encountered arguments that African American youth were not taking full advantage of the opportunities offered to them. He further tried to answer the criticism that African American youth were unresponsive to educational activities and lacked occupational ability. As Sutherland believed that the NYS was not specifically directed at the African American educational problem, this paper did not summarize the study. However, Sutherland discussed aspects of cultural and group dynamics of the learning process not only offered context to his paper but were

\footnotetext{
286 “Sutherland to Floyd Reeves, 10 January 1940," ACE Papers, Box 181, Folder American Youth Commission Negro Youth Study.
} 
worthy of inclusion into the files. ${ }^{287}$ Moving into the classroom, Sutherland described the effects of a compliant child both on the teacher's success and classroom management, acknowledging that the majority of these children come from middle-class families that have imbued in their children the necessity of education as indispensable to their ultimate success. Sutherland suggested that most teachers are unaware that these parents "are on her side" by reinforcing the standards of school back in the home. ${ }^{288}$

The individual studies were organized in a similar fashion with instructions to the test administrator, the instruments themselves, the scoring sheets, and various discussions on the creation of those studies. All material was in a very large folder in the E. Franklin Frazier papers' Box 131-106 containing the tests and test administration instructions for the surveys. In the instructions, the researchers asked the test administrator to secure honest answers from the children and provided specific recommendation on how to address particular test questions and time management issues, and how to bring both boys and girls together if the logistical arrangement did not permit. Undergirding all details was a constant theme to encourage the children to answer truthfully and be honest about their feelings.

An overview of administration is illustrative of the methodology and purpose of the study. In order for the results of the test to be valid, it was essential that the child's cooperation be secured. The instructions stressed the point that administrators needed to ask the children to help them, not order them to do so. The children were to receive

\footnotetext{
287 "Sutherland to Floyd Reeves, 23 January 1940," ACE Papers, Box 181, Folder American Youth Commission Negro Youth Study, 1-2.

288 "Sutherland to Floyd Reeves, 23 January 1940," ACE Papers, Box 181, Folder American Youth Commission Negro Youth Study, 181, 2-3.
} 
standard instructions before commencing the test and the administrators could modify the wording in the interests of naturalness, but should not change any of the "ideas" in making modifications. ${ }^{289}$ Administrators had to give the test in a recommended sequence: (1) Personal Values, (2) Personal Attitudes, (3) Occupation Ratings, (4) Color Ratings, (5) Race Attitudes, (6) Personal Data Sheet, and (7) Intelligence Test. Some leeway was given in the sequencing for the first and last section; giving the Personal Attitude Test it was desirable to test the girls and boys separately. ${ }^{290}$

First in the suggested sequence was the Personal Values Test, a two-page, short answer test asking the children about their personal values such as their fears as well as what kind of person they wanted to marry, what kind of person they thought they would really marry, and what work they saw themselves doing after finishing school. The children were also asked where they would like to visit and where they would like to move to in the United States. Second in the recommended sequence was the Personal Attitude Test. The test contained a 125 true/false questionnaire for middle school and high school girls asking a wide range of questions about home, school, community, Whites, police, friends, family, church, health, and feelings/emotions (see Appendix H). Third in the suggested sequence was the survey on Occupational Ratings. The test was a two-page document listing thirty occupations reflective of the job market available to children leaving high school. The jobs ranged from manual labor and field work to professionals such as doctors and lawyers (see Appendix I). On the second page, the

\footnotetext{
289 "Sutherland to Floyd Reeves, 23 January 1940," ACE Papers, Box 181, Folder American Youth Commission Negro Youth Study, 1-3.

290 "Sutherland to Floyd Reeves, 23 January 1940," ACE Papers, Box 181, Folder American Youth Commission Negro Youth Study, 3-4.
} 
children were asked what they would like and not like to be. They were also asked which jobs were most and least important. Finally, they were asked to go back, and in Column 2 check a box if a Negro had a good chance of getting that job if he wanted it.

The "Color Rating" test was three-page document asking children to label various members of their family, friends, community, teachers, and their principal by one of six skin colors listed from left to right:

\begin{tabular}{|c|c|c|c|c|c|}
\hline Black & Dark Brown & Brown & Light Brown & Yellow & White \\
\hline
\end{tabular}

On the second page, the children were asked to list all in their family from youngest to oldest. The children taking the test was reminded to include themselves, too. The children were then asked to rank them based on who was the best. On the last page, the children were asked three profound questions:

1. Which color do you think is it best to be? Why?

2. Which color do you think is the worst to be? Why?

3. Which color would you like to be? Why?

Fifth in the sequence was the Race Attitudes Test. This three-page, sixty-four-item questionnaire was the most striking of all the tests. It brought the reader and the children who answered the questions to the center of a racialized America by answering true/false questions. The questions were simple true/false with number eight representative of the test:

8. No matter how nicely he treats a colored person, a White man doesn't really mean it.

The questions are illustrative of the situation faced by African Americans in the period and how researchers chose to record and analyze the findings (see Appendix I). 
Folder 5 also contained other documents relating to various tests, questionnaires, and measurement tools that are instructive to understanding the tests and their administration. Though the vast amount of material in folder came from the children interviewed, the NYS also collected information from the teachers and the schools. The Teacher's Rating Form asked teachers of the students taking the tests to evaluate the students. The form started with sixteen various behavior problems such as stealing, cheating, and lying, asking the teachers to evaluate the children based on the following choices:

\begin{tabular}{|c|c|c|c|}
\hline $\begin{array}{c}\text { Has never } \\
\text { Occurred }\end{array}$ & $\begin{array}{c}\text { Has Occurred } \\
\text { Once or Twice } \\
\text { but not more }\end{array}$ & $\begin{array}{c}\text { Occasional } \\
\text { Occurrence }\end{array}$ & $\begin{array}{c}\text { Frequent } \\
\text { Occurrence }\end{array}$ \\
\hline
\end{tabular}

The negative questions were followed by nine personal characteristics, such as cooperativeness, intelligence, and interest in school. The instructions for test administration emphasized the need for clarity with respect to several test questions that contained slang and colloquial terms. It was also clear researchers familiar with the population wrote the test language. I believe the examples in the Frazier Papers were in fact written by Frazier as he had done a tremendous amount of prior work in the field.

The NYS made efforts to spread the news of their work and results in popular media. A significant effort was aimed at the popular literature and, in 1938, Sutherland thanked Brandon for work he accomplished in LIFE and TIME. They were much interested in Dr. Zook's statement of what ACE expected from study. ${ }^{291}$ As the public was

\footnotetext{
291 "Letter from Robert Sutherland to Arthur Brandon, July 1, 1938," NYS Papers, Box 181, Folder American Youth Commission Negro Youth Study.
} 
made aware of the NYS, much effort went into preparing the study and the discussions were many and intense. By 1938, reports increased as the study became close to operational.

Sutherland reported to the AYC that research workers and assistants were busily conducting field investigation following the basic question of the effects (if any) upon the personality of African American youth of their racial minority status. They were looking at the entirety of adjustments, aggressions, frustrations, and the gains which youth experienced while being subjected to controls of social class and caste.

- To understand the social adjustment of Negro youth, the researchers examined the cultural environment in which they lived. Their observations contained the obvious ecological and social organizations along with a variety of data reflecting the "intimate controls within the Nero social world itself." These included life histories, attitude tests, guided and unguided interviews, and other approaches to complete the case histories.

- Locations where research was conducted included New York, Chicago, Washington, Louisville, Greensboro, New Orleans, Natchez, Nashville, and five rural counties in five Southern states. Atlanta was on the possible list.

With increasing details in the reports, Sutherland suggested each city was to be a separate report and should be allowed to go past a predetermined page limit of 150 pages. The researchers needed more space to present their work fully. Discussion also occurred on how to present the findings; ideas ranged from separate volumes, to chapters, to some of the work being published by respective directors through their university presses. ${ }^{292}$ As the word spread of the creation of the report, interest in working in the study emerged. Vivian Osborne-Marsh, supervisor of the Division of Negro Affairs for the State of

292 "Letter from Robert Sutherland to Arthur Brandon, September 17, 1938," NYS Papers, Box 181, Folder American Youth Commission Negro Youth Study. 
California, requested the far west be included in the study labeled "What the Minority Racial Status of Negro Youth has Done upon Their Personality Development."293

As the NYS report was being written in 1938-1939, Sutherland suggested care should be taken in its writing. With the many scholars writing the various chapters, Sutherland reiterated his concerns on writing that each team keep to its charge of creating something new without stating the obvious or repeating previous articles or books. ${ }^{294} \mathrm{In}$ 1939 , more responses to the NYS reached the team. One of the team members reviewed letters and comments on a proposal by "Mr. Canady," who suggested that there was still a need to prove more definitively that intelligence testing as applied to African American youth was incorrect because of educational and cultural limitations. Mr. Canady suggested they spend their time and resources on work that was not so well established. Canady went on to say that since there are still many who "look upon the Negro as an inferior type, I presume such a study as this would serve a useful purpose."295

In the middle of Box 181 was a reality check for the researchers of the NYS and for posterity. Quoted several times, Sutherland reported Frazier was conceptually going to present on the cultural and social world of African Americans in the border states. That discussion would serve at the background for further analysis of personality factors in the

\footnotetext{
293“American Youth Commission: Negro Youth Study,” NYS Papers Box 181, Folder American Youth Commission Negro Youth Study.

294 “Sutherland to Rainey, 30 January 1939,” NYS Papers, Box 181, Folder American Youth Commission Negro Youth Study.

295 "Reading of the Reynolds Letter," NYS Papers, Unknown writer and Hand-Written, date approximately January 1939, Box 181, Folder American Youth Commission Negro Youth Study.
} 
development of African American youth. ${ }^{296}$ Sutherland also offered information to Rainey on an incident at the Hotel Commodore where Frazier was apparently denied a room because he was African American. ${ }^{297}$ Sutherland wrote Rainey they had notified the hotel that the guests would be mixed, colored, and White. With that letter sent, and no response to this disclosure, all should have been ready. Sutherland suggested that if Rainey would send a grievance, he should have all the facts. ${ }^{298}$

\section{How the Study Worked}

Of interest to the working of the NYS was Folder 12 of the Frazier Papers, where a file folder dated February 12, 1938 contained a large stack of typed, identical form letters that were used to introduce a researcher in the field conducting NYS research. The document was intended for the general public of the study:

\section{TO WHOM IT MAY CONCERN:}

This is to introduce Mrs. Thelma L. Colman, who has been employed by the American Youth Commission on a Study of the Effect of the Minority Status of the Negro on the Personality Development of Negro Youth.

The purpose of this study is to determine how the organization of the Negro community and its relation to the larger community affect the economic and social adjustments of Negro Youth and the influence of these adjustments on his personality.

Because of the importance of this Study for the future of the Negro, we would appreciate your cooperation in placing at the disposal of Mrs. Colman whatever information pertinent to the Study she desires.

\footnotetext{
296 “Sutherland to Rainey, 31 March 1939," NYS Papers, Box 181, Folder American Youth Commission Negro Youth Study.

297 “Sutherland to Rainey, 15 April 1939," NYS Papers, Box 181, Folder American Youth Commission Negro Youth Study.

298 "Sutherland to Rainey, 15 April 1939," NYS Papers, Box 181, Folder American Youth Commission Negro Youth Study.
} 
Very Truly yours,

Franklin Frazier, Director

Middle States Division ${ }^{299}$

The one-paragraph introduction to the coversheet/factsheet illustrates the presentation to the public of the rationale of the NYS:

This study of Negro youth, which is being sponsored by the American Youth Commission, is an attempt to discover the peculiar problems of Negro youth. In order to secure worthwhile information on these problems it is necessary that Negro youths give expression to their feelings, thoughts and behavior in regard to their problems. At the same time the value of these expressions will depend upon the frankness and truthfulness of the writers. Therefore, it is desired that you write frankly and truthfully concerning your feelings, thoughts and behavior. The information which you give will be treated confidentially. ${ }^{300}$

At the core of many of the surveys was the question of how African Americans

felt about themselves and Whites. In a "Guide for Writing Documents on your

Experiences, Thoughts, and Behavior Growing out of the Fact that You are Colored or a

Negro," the nine questions asked inform the dissertation well (see Appendix J).

\section{What Next?}

Dated after the NYS was completed, there are documents discussing what should be done next. These discussions fit the trajectory taken by the NAACP's Legal Defense Fund and prefigured Brown. One document makes it clear where this type of work was heading and the sense of the researchers. On February 16, 1944, Dr. L. S. Tierman of the University of New Mexico received a letter of thanks for his letter to Zook in support of the proposal, then called, "Waste from Race Discrimination in Education." Zook was also beginning solicitations for committee members and for help with fundraising to support

\footnotetext{
299 “July 12, 1938," Frazier Papers, Box 131-40, Folder 12.

300 “Coversheet for NYS Questionnaire," Frazier Papers, Box 131-106, Folder 5.
} 
this proposed committee. ${ }^{301}$ In a follow-up to Zook, Tierman, equipped with more information on the proposed project, offered feedback. Tierman noted the work should be done with "great tact." He was pleased that the ACE had agreed to take on this project as he had previously asked the U.S. Office of Education to address what he saw as a national problem but was rejected by them. The study, he said, should be all agenciesdenominational, political, educational, and commercial. He also alluded to groups who had "discovered" techniques to solve this problem and that the work should be reported via a handbook and be evaluative in nature. ${ }^{302}$

As the committee came together, Ralph Bunche sent Zook a letter with suggestions to the project proposal. Bunche clearly demonstrated the influence of WWII from his perspective as an employee of the Office of Strategic Services. Bunche asked to add language including discussions on post-war economies, educational opportunity with respect to the majority then and now, and international affairs and political warfare. He then stated he was "happy to serve." 303

On February 26, 1944, the ACE proposed a report on "The Education of Minority Races in the United States.” The introduction suggested there was a national concern with race relations naturally reflected in the administration and operations of all levels of education. The report also suggested that recent court cases had focused public attention upon certain issues with a particular emphasis on education. The committee

\footnotetext{
301 “22 February 1944, Letter from Tierman to Zook,” ACE Papers, Box 130, Folder Committee on Education of Minority Racial Groups 1943-1948.

302 “16 February 1944, Letter from Tierman to Zook,” ACE Papers, Box 130, Folder Committee on Education of Minority Racial Groups 1943-1948.

303 “25 February 1944, Letter from Bunche to Zook,” ACE Papers, Box 130, Folder Committee on Education of Minority Racial Groups 1943-1948.
} 
proposed a project: “The Preparation and Implementation of a Report on the Waste

Resulting from Race Discrimination in Education and on ways Recently Found to Reduce this Waste." ${ }^{304}$

In the opening of the proposal, the committee made it clear that the report should be an account of racial inequalities in education not as an ethical matter, but as a political matter:

- Relations of racial inequalities is education to economic inequalities

- Relations of racial inequalities in education to prevailing attitudes regarding racial groups; the capacity of the minority community, and of the total community, to absorb educated persons of racial minorities

- The nature of this waste has direct economic waste

- Waste in personality ad self-confidence; in both minority and majority groups

- Waste of national effectiveness in international affairs and in particular warfare

- A short review of the changes in educating or racial minority for the past 80 years. ${ }^{305}$

Once the work was collected, the proposal suggested, not only would working groups write their respective reports, conferences would be held in the communities that had been studied. This would offer a chance to gain feedback to the report and to assess the success or failure of work done by those communities. Finally, a finished report would be created and disseminated to selected leaders in biracial and multiracial communities with the promotion and guidance of discussions based on the report. ${ }^{306}$

\footnotetext{
304 “A Proposal for a study of The Education of Minority Races in The United States," ACE Papers, Box 57, Folder National Advisory Committee on Education, Committee on Negro Education, 1.

305 “A Proposal for a study of The Education of Minority Races in The United States," ACE Papers, Box 57, Folder National Advisory Committee on Education, Committee on Negro Education, 2.

306 "A Proposal for a study of The Education of Minority Races in The United States," ACE Papers, Box 57, Folder National Advisory Committee on Education, Committee on Negro Education, 3.
} 
Finally, on the last page of the proposal, the committee suggested three possible questions that they might also address. In a reference to a 1938 work by Charles Spurgeon Johnson, A Re-Study of the Higher Education of Negroes, the committee raised the questions:

- What have been the effect of the Gainesville decision?

- To what extent and in what areas are highly educated Negroes now employable in the Negro community, in the whole national community as compared to $1937 ?^{307}$

Second was a question that had arisen about how the ACE may serve the recently organized city and state committees on interracial relations. Third was an exploration of the problem of better selection of promising Negro students and better support for their education. In the final paragraph, the committee focused on the basic issue of the waste of human capital should finances not be secured. ${ }^{308}$

\section{Major Texts}

Ultimately, the worth of the efforts of the NYS should be measured in the text and documents produced by the researchers. The chosen works for discussion are selected works are a selection across the various efforts over a four-year period marking the height of the NYS in its efforts for the AYC. In Youth and the Future: The General Report of the American Youth Commission (1942), a retrospective question was raised: Why the Commission? In the forward, the authors of the report identified the postwar world as the

\footnotetext{
${ }^{307}$ Charles Johnson was the president of Fisk University and involved in many ACE papers concerning Negro education for over 30 years.

308 “A Proposal for a study of The Education of Minority Races in The United States," ACE Papers, Box 57, Folder National Advisory Committee on Education, Committee on Negro Education, 4.
} 
context for what America needed to do in dealing with youth. ${ }^{309}$ In the introduction, Commission Chairman Owen D. Young gave the overarching purpose of the report as a program based on experience from the past, adjusted to the harsh realities of the present, and adequate for the foreseeable needs of the future. In 1942, the realization of the postWWII realities had set in. ${ }^{310}$

With the backdrop of the war in Europe, America began to mobilize and become the arsenal for democracy. The commission looked at how to bring youth unemployment down through employment in private industry. In September 1939, the pamphlet $A$ Program of Action for American Youth again sounded the alarm: the Commission felt obliged to emphasize the fact that, whether in war or peace, any nation interested in selfpreservation must see to it that the young have grown into useful citizens. ${ }^{311}$ Halfway through the report, in a chapter on Occupational Adjustment, the report offers a threepage sub chapter on "The Special Problem of Negro Youth." That special problem was racial discrimination. The report's mission was to analyze the unemployment problem of the day and to offer solutions that would guarantee full employment following the conclusion of WWII. However, with respect to African American youth who had a difficult time securing unskilled positions, the issue of racial discrimination was an additional burden compounding their employment situation. In spite of the massive

\footnotetext{
${ }^{309}$ Youth and the Future: The General Report of the American Youth Commission (Washington, DC: American Council of Education, 1942), v.

${ }^{310}$ Youth and the Future, ix.

${ }^{311}$ Youth and the Future, xi-xii.
} 
industrial expansion in the run up to America's entry into WWII, there was some improvement but, overall, the situation was still bleak. ${ }^{312}$

What could be done? In concluding the section, the report described the problem as acute and called for constant attention and assistance from "men of good will." It was to the employers and unions that the greatest responsibility fell, and both were aware of the obligation to pursue policies of justice. Schools and public employment offices were seen as strategic positions that should make every effort toward securing equitable opportunities for African American youth. With one in ten youth being African American, their frustration and bitterness brought an element of weakness to the nation at time that all were looking to be strong. ${ }^{313}$

Addressing the problem with education, the report clearly saw the fundamental problem as being the reliance on local taxes and decline in revenue from falling property values with concomitant school taxes. Compounding this problem were underlying systemic issues in the seventeen segregated schools, including:

- Markedly shorter terms

- Grossly inferior housing and equipment

- Substantially lower salaries for teachers

- Distinctly inequitable financing as compared to White schools in the same state $^{314}$

Recent federal and Supreme Court cases upheld petitions based upon the fourteenth amendment that African American teachers who were equally qualified as their White colleagues receive the same salary. With some hesitancy, the commission

\footnotetext{
${ }^{312}$ Youth and the Future, 149-150.

${ }^{313}$ Youth and the Future, 151.

${ }^{314}$ Youth and the Future, 130-131.
} 
stated some kind of federal support for local schools should be forthcoming in order that children, especially minority children, to not be burdened by living in homes with low property values, thereby insuring a low revenue stream for their schools. ${ }^{315}$

In the work In Minor Key: Negro Youth in Story and Fact (1940), Ira De

Augustine Reid conducted a literature review to identify what research had been done to date on American youth. The work formed the basis of research to come that was being developed for implementation in the early 1940s. In the forward, NYS director Floyd W. Reeves stated:

The disadvantages that have been associated to the condition of being a Negro in the United States have made it inevitable that the interests of the Negro people should figure prominently in American social and economic problems. Realizing this fact early in its history, the American Youth Commission decided that it would be necessary to make extensive special studies of the conditions and needs of Negro youth. ${ }^{316}$

To create the compilations, foundational questions had to be asked. ${ }^{317}$ In Minor

Key, these questions set the trajectory:

- How healthy are Negro youth?

- How well organized their leisure time?

- How many are in jail

- Living conditions

- How long do they stay in school?

- What kind of work or relief have they secured ${ }^{318}$

\footnotetext{
${ }^{315}$ Youth and the Future, 131.

${ }^{316}$ Ira DeA. Reid, In Minor Key: Negro Youth in Story and Fact (Washington DC: American Council on Education, 1940).

${ }^{317}$ Reid, In Minor Key, Preface.

${ }^{318}$ Reid, In a Minor Key, Contents.
} 
These questions drove the work of the NYS. Reid began by introducing African

American youth's condition:

More so than any other youth, their way of life is roughened and obstructed, from birth to death, by the factor of race. Race may not dominate but it throws across its shadow across every phase of Negro life in the North and envelops every aspect of life in the South. From birth to death he lives not only and outer environment of economic and social problems of adjustments, but an inner environment of being Negro - in the United States which in the United States in interpreted as inferior, impoverished, inconvenienced. Both of these environments are real, effective, and inescapable. They not only determining the status of Negros but they also create the Negro personality - a personality that has had to develop in whatever way and to whatever extent it could within the iron ring of prejudice. $^{319}$

The African American condition was described in In Minor Key:

- Mortality is higher among colored than among White persons.

- Metropolitan Life Insurance reported that Colored females had 3.5 the number of deaths as among White females. Males had 2.5 times more death than Whites.

- From the National Health Survey Negro disability was 43\% higher in Atlanta, Dallas, Newark, and Cincinnati; pneumonia was 2 times higher, many chronic diseases were also significantly higher

- The ratio of patients for Negro and White physicians was 3,125 to 800 .

- Maternal mortality exceeded White maternal mortality by 70 to $100 \%$.

- Tuberculosis was vicious: $86 \%$ higher for males and $169 \%$ higher for females. For 10-14-year old's, the Negro death rates were 10 times higher!

- Syphilis was 5 times as high. ${ }^{320}$

Supplying a much-needed reference, Louise Arnold Menefee and M.M.

Chambers' American Youth: An Annotated Bibliography (1938) was an annotated

bibliography which was part of a series of preliminary reports prepared by the staff of the

Commission. With 2,500 annotated entries representing contemporary writings in a score

of major areas of human knowledge, it was the most comprehensive survey and digest of literature of youth problems available. It identified many facets of our complex modern

\footnotetext{
${ }^{319}$ Reid, 4.

${ }^{320}$ Reid, 15-20.
} 
society, and was designed to be useful to persons of all ages in all walks of life who wished to keep abreast of current thought regarding the care and education of youth. ${ }^{321}$

From the authors:

It is for those who seek to consider many facets of American youth problems that this bibliography has been prepared. In a hundred cities and a thousand towns, and in uncounted rural communities in three thousand counties, there are citizens whose social conscience and parental interest give them a high stake in the welfare of youth. ${ }^{322}$

The purpose of this volume is to facilitate the dissemination of knowledge and understanding of the problems of youth in the modern society. It is hope that it will prove serviceable to many persons for that purpose. ${ }^{323}$

Contents:

Attitudes of Youth

Youth in the Depression: Unemployment ad Relief

Employment and Vocational Adjustment

Education

Health

Family Life and Housing

Citizenship, Character, and Religion

Delinquency and Social Maladjustment

Social Organization, Research, and Surveys

Rural Youth ${ }^{324}$

Introduction to Chapter XVII: Negro Youth:

Far-sighted pioneers in the promotion of interracial understanding have already accomplished much to dispel unfounded hatreds and prejudices, but none can deny that in the main Negro Youth face formidable handicaps in the shape of inferior education facilities, poor housing, disproportionate health hazards, and limited vocations opportunities. This circumstance makes study of the prospect of Negro youth especially urgent. A portion of the none-to-abundant recent literature bearing on the subject is referred to below.

\footnotetext{
${ }^{321}$ Menefee and Chambers, v.

${ }^{322}$ Menefee and Chambers, $x$.

${ }^{323}$ Menefee and Chambers, xi.

${ }^{324}$ Menefee and Chambers, vii.
} 
To anyone who was educated in the American K-12 system, many of the techniques, instruments, and basis for the surveying used in the NYS is familiar. This was not generally the case in the period under review, nor for the legal system, which only just becoming familiar with this research. Acknowledging the work of Du Bois in Philadelphia as well as the Army's psychological testing conducted as America went into WWI, the work, techniques, and tools of the NYS fell clearly within sociology, social psychology, and the latter efforts of the CRM.

There is an unease when dealing with archival material that seems obsessed with color. The surveys may seem harsh when understood as having been administered to young children. However, the belief that the damage being caused to those children by racial segregation seemingly outweighed the discomfort that the survey may have placed caused. With historical hindsight, we see how the efforts of the NYS and others figured into the Brown decision and began the process to end de jure racial discrimination. 


\section{CHAPTER VI}

\section{DISCUSSION}

Through a historical analysis of archival, secondary, and general reading literature in this dissertation, I addressed the question: "How does the work of the NYS fit into the historical development of social sciences during the early civil rights movement?"325 Secondarily, I addressed the historical silence surrounding the work of the NYS and the place of Black sociology in the research question. In addressing the research questions, it is clear that the work of the NYS was part of the history of sociology and the CRM. What cannot be ascertained from the documents studied is a direct connection between the NYS and the NAACP, the Legal Defense Fund, or Thurgood Marshall and the attorneys who argued Brown and prior cases in which social science research was systematically brought to bear in the fight to end racial segregation.

As epitomized by the Kenneth and Mamie Clark Doll Experiments, the NYS fits into the historical development of sociology in the CRM that demonstrated that African American children were heavily influenced by segregation and especially so in their segregated schools. The NYS suggested that emotional damage done to the children must be ended and that segregation is a threat to the children and the nation. With the coming of WWII, the nation turned to fight a world war and the study ended abruptly. The wealth of information sat in the various reports, yet spoke clearly of the reality of segregated schools. In 1951, the NAACP's Legal Defense Fund changed tactics and began to apply social sciences research in court cases that would eventually lead to that figuring

\footnotetext{
${ }^{325}$ Denzin and Lincoln, 38.
} 
prominently in the NAACP's arguments in Brown and to its continued use in winning cases against racial segregation to the present.

George Santayana's 1905 remark, "those who cannot remember the past are condemned to repeat it," ${ }^{326}$ has weighed over the dissertation as a discovery of littleknown reports, studies, and research reminds the reader that many of the debilitating social and economic conditions, affecting African Americans 70 years ago, continued to exist to the present. In the struggle for equality, the forces of segregation were many, powerful, and well-entrenched. Seeking to understand the struggle for integration, this dissertation was hindered by the almost hidden nature of the NYS and similar reports, such as the Jones Report. More research on this situation is called for, as it may offer a model for those conducting social science research to ensure, as much as possible, that their findings reach as wide an audience as possible, and as often as possible.

Presently, the silence surrounding the NYS is deafening but may primarily be understood by the masking effects of the two organizational umbrella structures supervising the work of the NYS. The immediate supervisory structure, the AYC, was acknowledged in the literature and popular media. On several occasions, references to the NYS in literature produced by the AYC cited the AYC, not the NYS. This clouding of the source is troubling and requires further research. Adding more opaqueness is the domination in the literature of the overall supervisory structure of the ACE. The ACE was and still is a large, well-known, and well-respected professional organization. Its position in education, and particularly in higher education, is significant.

\footnotetext{
${ }^{326}$ George Santayana, Reason in Common Sense (New York: Charles Scribner's Sons, 1905), 284.
} 
Secondarily, in the question of masking, there must be an appreciation of the role and influence private funding organizations have on those they fund. To believe that researchers are free to research as they wish would be naive. Similar realities also exist for those researchers who conduct projects for Federal or State efforts. As can be seen from Du Bois' struggles in producing his Encyclopedia of the Negro, the deafening silence of the NYS most also be understood as having a political component of requiring researchers to satisfy funders and funding organizations.

It can be easy to attribute all, or at least much, of the silence of the NYS on researchers currying favor of a major donor. However, when looking at the earliest discussions about the creation of the NYS from 1929 to 1930 to the final reports and correspondences of the various researchers of the study in 1941, it is clear that the researchers grew in their belief that the study must be more than just a report on the financial conditions of African Americans. The documents demonstrate that from a cautious position in the early 1930s, the researchers grew in their beliefs (beliefs that would fit well with Du Bois' Black sociology) of the insidious effects of racial segregation on African American children. These researchers would eventually create reports that would "assess the waste in human resources."

The growth in this apparent boldness should also be understood in the context of the late 1930s and early to mid-1940s. From an increasing knowledge of the abuses by Nazi Germany and, in particular, its racial policies, eugenics in the United States came to an end. For sociology, this was a point of inflection as sociology shifted from Eugenics and racism to social conditions, as demonstrated by studies such as the NYS. From inside 
and outside of the academy, and with support from activist scholars such as Du Bois, America's racism came under a greater spotlight and changes were in the wings.

While the work of the NYS certainly fits within the shift of sociology away from eugenics, and with so many of the leading Black sociologists working on the NYS and other studies such as An American Dilemma, should we not expect to have seen a direct link to Gunnar Myrdal, the NAACP, and to footnote 11 in Brown? Finding a direct link in history is extremely difficult, and it could not be established by the documents reviewed for this dissertation. However, if we consider the work of the NYS in terms of social networking, much of the foundations of that work done during the period of concern in this dissertation, ${ }^{327}$ then we might well see that a "network" of Black sociologists, working from various HBCUs, privately funded studies, and positions in both state and federal governments, were collaborating to end racial segregation. Central to this possible network was the associations of the key researchers with the NAACP.

As key as the NAACP was in the CRM, at its core since its founding in 1910 was Du Bois who had left the academe to join the fledgling association. Though having left the university, Du Bois continued his activism as the editor of The Crisis. In his latter writings, Du Bois' was clear in the reason for move away from his position in the university:

Stepping therefore in 1910 out of the ivory tower of statistics and investigation, I sought with my bare hands to lift the earth and put it in the path which I ought to go. 328

\footnotetext{
${ }^{327}$ See the works of sociologists Georg Simmel (1858-1918) and William Richard Scott.

${ }^{328}$ David Levering Lewis, W.E.B Du Bois: Biography of a Race 1868-1919 (New York: Henry Holt, 1993), 407-409.
} 
As the premier organization for African Americans, researchers like Frazier and Bunche were active members of the association. Myrdal had connected with Frazier and the NAACP to enable him to reach out and secure over 75 White and African American scholars for his The American Dilemma. Circumstantially, there appears to have been a network in the NAACP of researchers, including those from the NYS. Further research is necessary to fully substantiate my claim of a link of NYS to Brown via networks with material from the NAACP archives and the personal papers of the individual researchers.

As to the question of the place of the NYS in the history of Black sociology, it is clear that from the position stated by Du Bois in the early twentieth century that the work of the NYS should be considered a part of this history. The majority of researchers were African American scholars who were trained by African American scholars. Their coursework and dissertations reflected the realities of the African American condition; they were publicly active in using their research to change that condition, and they actively sought and secured private donors to support their work. The NYS was a part of this history and warranted further study based upon its scope, research, and results.

As the scholars work on challenging racial segregation, their fight was also made harder as the nation resisted efforts to desegregate, most notably was the policy of redlining that still resonates today. Three years after the creation of the Federal Housing Administration and two years after the creation of the Federal Home Loan Bank Board, the NYS began. However, its work was made even more difficult as these two Federal programs would have a major part in redlining America's cities and suburbs. ${ }^{329}$ The

\footnotetext{
${ }^{329}$ Redlining was defined by sociologist John McNight as practices that fenced off areas where banks would avoid investments based on communities of color often affecting the ability of African Americans to secure home loans in middle class neighborhoods.
} 
creation of "residential security maps," creating "Type A," "Type B," and "Type C" neighborhoods ascribing increasing levels of financial risk, effectively redlining. In some respects, what the NYS was asking to end, redlining prevented. The problem of redlining would continue legally for forty more years until struck down by the courts. However, the residual effects, and covert use, of redlining are still being addressed today.

Perhaps the most powerful of all evidence came in chapter four of this dissertation with the letter from Dr. Charles Roberts' to Mayor Fiorella La Guardia, introduced as commentary on the 1935 Harlem Riots. As part of a little-known collection of letters to Mayor La Guardia, Roberts' biting commentary and description of the divisions, attitudes, and moods of his community were powerful and suggestive of the strengths in documentary narrative. Particularly powerful, Roberts noted the fractures in the community, the deep-seated issues that predated the riot, the importance of the NYS, and his fears for the future of his community.

Roberts' letter to La Guardia in the Frazier papers is a moving moment for anyone reading the document but must be understood to be part of what Frazier, a member of the NYS, thought was useful to his part of the project. The power of the document and its use by Frazier represented to me the signature tool in both historical and sociological research. It also suggests that when looking at major studies in this period of civil rights, prior research frequently suggested some of the same problems existed previously. Implications of serial issues that were not acted upon or parried warn researchers, especially those in the social sciences, of the significance of understanding the past. As the NYS visited classrooms across America, the Jones Report fell to the background. This lesser known report demonstrated the tremendous need to support African 
Americans almost thirty years before the findings of the NYS. As debatable as the Moynihan Report came to be, it reported on what was known and what could have been acted upon.

While nearing the completion of the dissertation, the forty-fifth anniversary of Milliken v. Bradley $(1974)^{330}$ was commemorated with a broadcast on National Public Radio (July 24, 2019). The Milliken case dealt with the planned busing to desegregate public school students across school district lines in metropolitan Detroit. The case had a profound effect on the progress toward integrated public schools initiated by the Brown decision of 1954. The technical ruling cleared the confusion over the distinction between de jure and de facto segregation. By a 5-4 decision, the court confirmed that segregation was allowed if it was not an explicit policy of an individual school district. In particular, the court held school systems not responsible for desegregation across district lines unless it could be shown that they had deliberately engaged in a policy of segregation.

The Brown decision of 1954 was 75 years ago and affected the entire nation. In 2019, the nation is still coming to terms with fulfilling the decision. Brown's effects reached far, but sometimes it seems to fade into our individual and collective pasts. In reality, it is has affected us all. While completing this dissertation, I realize that as a young child, I too was part of redlining, and a question from childhood finally received its answer: why did I never see an African American in school until college? Unbeknownst to myself, my parents moved our family from Brooklyn, New York, to Islip Terrace on New York's Long Island in 1963. In a 100 percent White community, we were the only non-Catholics in our neighborhood. This community, like many others on

${ }^{330}$ Milliken v. Bradley, 418 U.S. 717. 
Long Island, was effectively created and perpetuated by redlining as suggested by the plaintiffs in the original suits before Milliken was tried in the Supreme Court. To this day, Long Island still struggles with issues of diversity and equity.

In his dissent in Milliken, Justice Thurgood Marshall, who had 20 years before argued and won in the Brown litigation, the case would be damaging to Brown and the work of desegregation. Like the commemoration of Milliken, the discovery of the many documents, opinions, and actions found in the archives of the NYS have had the same effect upon me as Milliken had upon Marshall. Eighty years after the NYS entered the classrooms of African American students, bringing in the full force of the tools and skills of the social sciences, we continue to see African American children facing many of the same issues their grandparents faced in the 1930s and 1940s, that I saw in the 1960s, and that has been with this nation since Emancipation.

For the educational practitioner looking at the NYS as a model to do research, the methods of collection, the delivery of the instruments, and the care shown to be accurate and impartial, all suggest that the studies were done in good faith and done professionally. For researchers in education, the methods and results of the study are a model and reminder that many of the problems we address have deep-seated and historical roots in society and in the minds of the body politic. For education practitioners, the work of the NYS has direct implications for confronting several current structural issues related to African American students and their communities. 


\section{Retention Efforts ${ }^{331}$}

African American students do not need special retention efforts simply because they are African American but more so because of the intersectionality with other identities (i.e., being low-income, first-generation college students). Harper suggested that institutions become data-driven and transparent instead of hiding data because of fear of damage to the institution's reputation. ${ }^{332}$ Honest, transparent, well-conducted research that seeks to identify real issues that affect a section of people, positively or negatively, is paramount when seeking to improve learning conditions or to identify learning or persistence barriers. Social scientists should spearhead more research in higher education with the comprehensiveness show in the NYS.

Finally, of great interest is the role the NYS may have played in Brown. After an initial search into various archives, there appears to be a possible connection between several key individuals and organizations of the period and Brown, including Gunnar Myrdal and The American Dilemma (1944); the philanthropy of the Rockefellers through the GEB; and the NAACP' Legal Defense Fund. If such a connection can be conclusively established, then the NYS will become a documented milestone in the history of sociology and an important moment in the efforts of the NAACP to end legal segregation in America.

\section{Family Outreach}

As shown by the NYS, institutions should engage families and encourage them to

\footnotetext{
${ }^{331}$ Shaun R. Harper and the University of Pennsylvania, Black Male Student Success in Higher Education: A Report from the National African American Male College Achievement Study (Philadelphia: University of Pennsylvania, 2012).

${ }^{332}$ Harper, 2.
} 
participate in workshops, symposiums, and community education classes as well as other events that bring families together with students. Du Bois's 1899 study consisted of information gathered from door-to-door data collection. Du Bois understood the importance of family structure and conditions about African American people and seemingly influenced the NYS to study familial aspects to determine correlations between families and African American student performance.

\section{Diversity Efforts}

The focus on embracing and internalizing diversity should also be reflected in academic learning outcomes and intergroup relations on campus. Leadership should encourage honest, open discussions about race and related issues. Diversity is crucial to developing new and more current knowledge, while leadership diversity may help facilitate the development of new relationships with diverse communities and students. ${ }^{333}$ The books produced by the NYS through the ACE can be considered the roots of the social scientific arguments that dominated the first half of the Brown litigation - that racial prejudice and discrimination cause psychological damage to African American children, and that diversity fostered by integration is as valid today as it was then. Increasing diversity on college campuses may lessen the damage caused by racism that still exists on college campuses.

\section{Obstacles Faced by African American Students}

Many issues, such as the overrepresentation of African Americans in prison, underemployment or unemployment, and single-parent households, are not only due to

\footnotetext{
${ }^{333}$ Penelope Moore and Susan Toliver, "Intraracial Dynamics of African American Professors' and African American Students' Communication in Traditionally White Colleges and Universities," Journal of African American Studies 40, No. 5 (2010): 932-945.
} 
the poor decisions of some individuals, but also to deficiencies in American society created by policymakers, media bias, and systemic racism. After the NYS began its work, there quickly arose among its members a sense of urgency and outrage that America could have forgotten that its African American children, born into a world they did not create nor could change, had the right to enjoy the fruits of civil society and its prosperity, its legal system, and, most importantly, its schools. As the United Negro College Fund continues to remind us, "a mind is a terrible thing to waste." 334

In 2011, Wood suggested that psychological factors are one of the most significant barriers preventing African American students from achieving at similar rates as others, and that these psychological factors result from negative messages both inside and outside of the college environment. ${ }^{335}$ Clark took the work of NYS researchers and applied it to his work on the problem of self-hatred and group identity. These works and their findings were used against racial segregation by the NAACP in Brown.

Amazingly, and sadly, many of the same issues found in the early twentieth century are still relevant today and have a specific impact on African American children. It is interesting that HBCUs, from their inception until the 1970s, housed the vast majority of African American collegians, while today only about 11 percent of African American college students attend HBCUs. African American students seek diversity, leading them to move beyond the HBCU campus. However, in doing so, they are more likely to experience racism. Some of the same themes found in the research of the NYS remain relevant today.

\footnotetext{
${ }^{334}$ https://www.UNCF.org.

${ }^{335}$ J. Luke Wood, "Falling Through the Cracks," Diverse Issues in Higher Education 28 no. 18, p. 24.
} 
The relevance of the NYS today is steeped in the efforts of thousands of individuals, researchers, activists, and organizations over the 150 years since the Civil War and Emancipation. The struggle for America to come to terms with all its people and bring equity to every member of the society has been monumental and continues to this day. The snapshot that is this dissertation by no means suggests that the work of the NYS, AYC, or ACE were interstitial in the CRM swung prior to Brown. This dissertation suggests both the NYC and the sociology became parts of the CRM and are important in understanding sociology's role in the CRM and in K-20. 


\section{LIST OF REFERENCES}

\section{Primary Documentation}

American Council on Education Archives. Hoover Library, Stanford University.

American Council on Education. A Proposal for the Development of a Comprehensive Program for the Care and Education of American Youth. Washington, DC: American Council on Education, September 16, 1935.

- Youth and the Future: The General Report of the American Youth Commission. Washington, DC: American Council of Education, 1942.

Charles Johnson Papers, Fisk University Archives.

Franklin; Access to the FDR Library Digital Collection. Marist University Archives.

Franklin Frazier Papers. Howard University Archives.

\section{Secondary Documentation}

Adair, Alvis V. Desegregation: The Illusion of Black Progress. New York: University Press of America, 1984.

American Council on Education. The American Youth Commission: Activities. Washington, DC: American Youth Commission, 1939.

Ashmore, Harry S. The Negro and the Schools. New York: Van Rees Press, 1954.

Baranchenko, Yevhen, et al. "A Case Study of Inward Erasmus Student Mobility in Ukraine: Changing the Nature from Intrinsic to Instrumental." In European Conference on Research Methodology for Business and Management Studies. Academic Conferences International Limited, 2014.

Beard, Charles. "Written History as an Act of Faith." American Historical Review 29 (January 1934): 227.

Becker, Howard, and Harry Elmer Barnes. Social Thought from Lore to Science: Sociological Trends Throughout the World to the Start of the Twentieth Century's Seventh Decade. New York: Dover, 1961.

Blaustein, Albert P., and Robert L. Zangrando, eds. Civil Rights and the American Negro: A Documentary History. New York: Trident Press, 1968. 
Bond, Horace Mann. The Education of the Negro in the American Social Order. New York: Octagon Books, 1966.

Brandt, Nat. Harlem at War. Syracuse: Syracuse University Press, 1996.

Brown v. Board of Education, 347 U.S. 483, 494 (1954).

Brunner, Edmund de S. Working with Rural Youth: Prepared for the American Youth Commission. Washington, DC: American Council on Education, 1942.

Byrd, Diane, Yasmin R. Ceacal. "A Modern Doll Study: Self Concept." Race, Gender \& Class, 24 (1) (2017), 186-202.

Calhoun, Craig, ed. Sociology in America: A History. Chicago: University of Chicago Press, 2007.

Commager, Henry Steele. “Twelve Years of Roosevelt.” The American Mercury 60 (April 1945): 392.

Coser, Lewis A. Masters of Sociological Thought: Ideas in Historical and Social Context. New York: Harcourt, Brace, Jovanovich, 1977.

Cravens, Thomas F. Exploring Human Society: An Introduction to Sociology. Dubuque: Kendall/Hunt, 1993.

Denzin, Norman K., and Yvonne S. Lincoln. "Introduction: The Discipline and Practice of Qualitative Research." In The Sage Handbook of Qualitative Research, 3rd ed., edited by Norman K. Denzin and Yvonne S. Lincoln, 1-4. Thousand Oaks: Sage, 2009.

Department of the Interior: Bureau of Education. Negro Education: A Study of the Private and Higher Schools for Colored People in the United States. New York: Negro Universities Press, 1969.

Eller, Jack David. Social Science and Historical Perspective: Society, Science, and Ways of Knowing. New York: Routledge, 2017.

Fosdick, Raymond B. Adventure in Giving: The Story of the General Education Board, A Foundation Established by John D. Rockefeller. New York: Harper and Row, 1962.

Foster, B. Brian. "Rewriting Wright: A Note on Perspective in Method and Writing.” In The New Black Sociologists: Historical and Contemporary Perspectives, edited by Marcus Anthony Hunter, 18. New York: Routledge, 2018. 
Furner, Mary O. Advocacy and Objectivity: A Crisis in the Professionalism of American Social Sciences 1865-1905. Lexington: University of Press of Kentucky, 1975.

Gaines, Kevin K. "Racial Uplift Ideology in the Era of "the Negro Problem," in Freedom's Story: Teaching African American Literature and History. Washington, D.C.: National Humanities Center, 2019.

Galbraith, John Kenneth. American Capitalism: The Concept of Countervailing Power. Rev. ed. Boston: Houghton-Mifflin Company, 1956.

"Harlem Disorders Bring Quick Action by City and Army: Police and Soldiers Patrol the Area." New York Times (1923-Current File), Aug 02, 1943. http://ezproxy.fiu.edu/login?url=https://search-proquestcom.ezproxy.fiu.edu/docview/106681087?accountid=10901.

Harper, Shaun R., and the University of Pennsylvania. African American Male Student Success in Higher Education: A Report from the National African American Male College Achievement Study. 2012.

Heise, Michael. "Brown v. Board of Education, Footnote 11, and Multidisciplinary." Cornell Law Review 90, no. 2 (YEAR): 293.

Hexter, Jack H. "Fernand Braudel and the Monde Braudellian...." The Journal of Modern History 44, no. 4 (December 1972): 480-483.

"History of the American Council on Education." Retrieved, 17 May 2019, https://www.acenet.edu/about-ace/Pages/default.aspx

Hovenkamp, Herbert. "Social Science and Segregation before Brown.” Duke Law Review, no. 3/4 (1985): 657-658.

Hunter, Marcus Anthony. The New Black Sociologists: Historical and Contemporary Perspectives. New York: Routledge, 2018.

—. "The Sociology of Stuart Hall." In The New Black Sociologists: Historical and Contemporary Perspectives, edited by Marcus Anthony Hunter, 49. New York: Routledge, 2018.

Jackson, John Phillip, Jr. "The Transformation of Social Science into 'Modern Authority' in Brown v. Board of Education, 1945-1957." PhD diss., University of Minnesota, 1996.

Kincheloe, Joe L., Peter McLaren, and Shirley R. Steinberg. "Critical Pedagogy, and Qualitative Research: Moving to the Bricolage." In The Sage Handbook of Qualitative Research, 4th ed., edited by Norman K. Denzin and Yvonne S. Lincoln, 163. Los Angeles, CA: Sage, 2011. 
Koselleck, Reinhart. The Practice of Conceptual History: Timing History, Spacing Concepts. Palo Alto: Stanford University Press, 2011.

Lau, Peter F., ed. From Grassroots to the Supreme Court: Brown v. Board of Education and American Democracy. Chapel Hill: Duke University Press, 2004.

Leuchtenburg, William Edward. Franklin D. Roosevelt and the New Deal. New York: Harper Row, 1963.

Lewis, David Levering. W.E.B Du Bois: Biography of a Race 1868-1919. New York: Henry Holt, 1993.

Markowitz, Gerald E. Children, Race, and Power: Kenneth and Mamie Clark's Northside Center. Charlottesville: University of Virginia Press, 1996.

McCulloch, Gary. The Struggle for the History of Education: Foundation and Futures of Education. London: Routledge, 2011.

McDonald, Lynn. The Early Origins of Social Sciences. Montreal: McGill-Queen's University Press, 1993.

McKee, James. Sociology and the Race Problem: The Failure of a Perspective. Urbana: University of Illinois Press, 1993.

Menefee, Louise Arnold, and Merritt Madison Chambers. American Youth: An Annotated Bibliography. Washington, DC: American Council on Education, 1938.

Minor, John Minor., and John B. Chase, Jr. Curriculum Principles and Social Tends. 4th ed. New York: MacMillan Co., 1969.

Moore, Penelope, and Susan Toliver. "Intraracial Dynamics of African American Professors' and African American Students' Communication in Traditionally White Colleges and Universities." Journal of African American Studies 40, no. 5 (2010): 932-945.

Morris, Aldon D. "Sociology of Race and W.E.B Du Bois.” In Sociology in America: A History, edited by Craig Calhoun, 504-505. Chicago, IL: University of Chicago Press, 2007.

- The Scholar Denied: W.E.B Du Bois and the Birth of Modern Sociology. Oakland, CA: University of California Press, 2015. 
Moses, Earl Richard. "Migrant Negro Youth: A Study of Culture Conflicts and Patterns of Accommodation Among Negro Youth.” Ph.D. dissertation, University of Pennsylvania, 1948.

Myrdal, Gunnar. The American Dilemma: The Negro Problem and Modern Democracy. New York: Harper and Brothers, 1941.

"National Humanities Center Resource Toolbox: The Making of African American Identity." Washington, D. C.: National Humanities Center, vol. III, 1917-1968, 12.

“The Negro Youth Study Completed.” Kansas American 8, no. 1 (November 14, 1941): 10.

"A New African American Identity: The Harlem Renaissance." National Museum of African American History. https://nmaahc.si.edu/blog-post/new-africanamerican-identit-harlem-renaissance, 2-3). Retrieve 23 August 2019.

"Our History: A History of Leading the Way." American Council on Education. https: //www.acenet.edu/About/Page/history.aspx.

Philogène, Gina. Racial Identity in Context: The Legacy of Kenneth B. Clark. Washington, DC: American Psychological Association, 2014.

Pierson, Sharon Gay. Laboratory of Learning: HBCU Laboratory Schools and Alabama State College Lab High in the Era of Jim Crow. New York: Peter Lang, 2014.

Platt, Anthony M. The Negro Family in the United States, by E. Franklin Frazier. Notre Dame: University of Notre Dame Press, 2001.

"Primary Documents, Library of Congress, Web Guide." Washington, D. C.: Library of Congress.

https://www.loc.gov/rr/program/bib/ourdocs/morrill.html retrieved 18 May 2019.

Reed, Touré F. Not Alms but Opportunity: Urban League and the Politics of Racial Uplift, 1910-1950. Chapel Hill: University of North Carolina Press, 2008.

Reeves, Floyd W. Special Problem of Negro Education. Westport: Negro Universities Press, 1970.

Reid, Ira De Augustine. In a Minor Key: Negro Youth in Story and Fact. Washington, DC: American Council on Education, 1940.

Robins, Richard. “Charles S. Johnson.” In Black Sociologists: Historical and Contemporary Perspectives, edited by James E. Blackwell and Morris Janowitz, 70. Chicago: University of Chicago Press, 1974. 
Rury, John. L. "Historical Research in Education." In Handbook of Contemporary Methods in Education Research, edited by Judith Greene, 323. Abingdon, UK: Routledge, 2006.

Santayana, George. Reason in Common Sense. New York: Charles Scribner's Sons, 1905.

Scott, W. Richard, and Gerald F. Davis. Organizations and organizing: rational, natural, and open system perspectives. New York, NY: Routledge 2016.

Smith, Stanley H. "Sociological Research and Fisk University: A Case Study." In Black Sociologists: Historical and Contemporary Perspectives, edited by James E. Blackwell and Morris Janowitz, 176-177. Chicago: University of Chicago Press, 1974.

Sorokin, Pitirim. Contemporary Sociological Theories. New York: Harper and Brothers, 1928.

Southern, David W. Gunnar Myrdal and Black-White Relations: The Use and Abuse off An American Dilemma, 1944-1969. Baton Rouge, Louisiana: Louisiana State University Press, 1994.

Sullivan, Patricia. "Prelude to Brown: Education and the Struggle for Racial Justice During the NAACP's Formative Decades, 1909-1934." In From the Grassroots to the Supreme Court: Brown v Board of Education and American Democracy, edited by Peter F. Lau, 166-167. Durham, NC: Duke University Press, 2004.

Swan, Alex. "The Harlem and Detroit Riots of 1943: A Comparative Analysis." In Berkeley Journal of Sociology 16 (1971-72), 86. as cited in P.L. Prattis, Pittsburgh Courier, July 3, 1943, as printed in "The Negro Press on the Riots," Common Ground, IV, Autumn, 1943, 101.

"The Social Studies in Secondary Education: A Six-Year Program Adapted Both to the 6-3-3 and 8-4 Plans of Organization and Report of thee Committee on Social Studies of the Commission on the Reorganization of Secondary Education of the National Education Association," National Council for the Social Studies (Washington, D. C.: Office of Educational Research and Improvement, 1916).

Tobin, Kenneth, and Joe L. Kincheloe, eds. Doing Educational Research: A Handbook. Rotterdam: Sense, 2006.

"The Vocational Guidance Magazine in 'Unemployed Youth.”" Monthly Labor Review 42, no. 1 (January 1936): 74-76. http://www.jstor.org/stable/41814702. 
Walker, Vanessa Siddle. Their Highest Potential: An African American School Community in the Segregated South. Chapel Hill: The University of North Carolina University Press, 1996.

Wecter, Dixon. The Age of the Great Depression: 1929-1941. New York: The Macmillan Company, 1948.

White, Hayden. The Content of Form: Narrative Discourse and Historical Representation, Baltimore, Maryland: Johns Hopkins University Press, 1990.

Wood, J. Luke. "Falling Through the Cracks." Diverse: Issues in Higher Education 28, no. 18 (2011): 24.

Wright, Earl, II, and Thomas C. Calhoun. "Jim Crown Sociology: Toward an Understanding of the Origin and Principles of Black Sociology via the Atlanta Sociological Laboratory." Sociological Focus 39, no. 1 (2006): 1-18.

Zunz, Oliver. Philanthropy in America: A History. Princeton, NJ: Princeton University Press, 2014. 
APPENDICES 
Appendix A - Published Academic Papers and Newspaper Articles

\begin{tabular}{lccc}
\hline Database & ACE & AYC & NYS \\
\hline U.S. Newstream & 18,960 & 9 & 0 \\
JSTOR & 8,934 & 574 & 6 \\
New York Times & 2,151 & 9 & 0 \\
ERIC & 1,612 & 0 & 0 \\
Academic Search Complete & 1,119 & 1 & 0 \\
Education Full Text & 442 & 0 & 0 \\
Wall Street Journal & 302 & 9 & 0 \\
PsycArticles & 77 & 6 & 0 \\
Social Sciences Full Text & 16 & 1 & 0 \\
History Reference Center & 16 & 1 & 0 \\
\hline
\end{tabular}

Published African American Newspaper Articles

\begin{tabular}{lccc}
\hline African-American Newspapers & ACE & AYC & NYS \\
\hline Baltimore Afro-American & 185 & 24 & 0 \\
Chicago Defender & 125 & 19 & 0 \\
New York Amsterdam News & 59 & 5 & 1 \\
African American Newspapers Series 1 & 86 & 12 & 3 \\
$1827-1998$ & & & \\
\hline
\end{tabular}

$1827-1998$

(ACE) American Council on Education, (AYC) American Youth Commission, (NYS) The Negro Youth Study ${ }^{336}$

\footnotetext{
${ }^{336}$ Electronic searches were performed July 25, 2018 in PsycINFO (1806-2011), PubMed (1946-2011); and Web of Science (Science Citation Index Expanded, 1899-2011; Social Sciences Citation Index, 1900-2011; Arts and Humanities Citation Index, 1975-2011).
} 
Appendix B - "The American Youth Commission, (1935-1942) by Randall Elliot Day Jr. list of AYC Publications"

- How Fare American Youth?, 1937, (186 pages)

- Secondary Education for Youth in Modern America, 1937, (137 pages)

- Surveys of Youth: Finding the Facts, 1937, (106 pages)

- American Youth: An Annotated Bibliography, 1938, (492 pages)

- Youth Tell Their Story: A Study of the Conditions and Attitudes of Young People, 1938, (273 pages)

- Equal Educational Opportunity for Youth: A National Responsibility, 1939, (189 pages)

- The Health of College Students: A Study of the Conditions and Attitudes of Young People, 1938, (273 pages)

- How to Make a Community Youth Survey?, 1939, (45 pages)

- The community and its Young People, 1940, (36 pages)

- Guideposts for Rural Youth, 1940, (167 pages)

- Matching Youth and Jobs: A Study of Occupational Adjustment, 1940, (277 pages)

- Time on Their Hands: A Report on Leisure, Recreation, and Young People, 1941, (266 pages)

- Youth, Family, and Education, 1941, (299 pages)

- Youth-Serving Organizations: National Nongovernmental Associations, 1941, (237 pages)

- Youth Work Programs: Problems and Policies, 1941, (195 pages)

\section{Publications of the NYS by Day:}

- Children of Bondage: The Personality Development of Negro Youth in the Urban South, 1940, (299 pages)

- In Minor Key: Negro Youth in Story and Fact, 1940, (134 pages)

- Negro Youth at the Crossways: Their Personality Development, 1940, (301 pages)

- Color and Human Nature: Negro Personality Development in a Northern City, 1941, (310 pages)

- Color, Class, and Personality, 1942, (135 pages)

- Growing Up in the Black Belt: Negro Youth in the Rural South, 1941, (360 pages)

- Thus, Be Their Destiny: The Personality Development of Negro Youth in Three Communities, 1941, (96 pages). 


\section{Appendix C - 1930 Problems and Plans Committee Minutes.}

A. What is the relation of the problem or plan to the field of education as a whole? Does it fill a present gap? Three major groups of inquiry were envisioned.

i. Number I comprise all studies relating to human beings, as they grow and unfold chiefly from within, their interests and aspirations, abilities and disabilities at various stages of life. These studies are based upon psychology, medicine, psychiatry, anthropometry, nutrition, etc.

ii. Number II comprises all studies that relate to the world without in which the individual must find a place, to collect or cooperative life, particular the needs and problems of the new industrial society into $\mathrm{w}$ which our world is moving, and the preset or prospective freedom, happiness, ad wholesome functioning of the individual in that life. These studies are based on social psychology, anthropology, sociology, economics, law, political sciences, ethics, etc.

iii. Number III comprises all studies relating to the educational process of society, purposed or unpurposed, including the family, church, vocation, press, theatre, monition pictures, libraries, museums, radio, as well as the school, by which the inherent growth of the individual is modified by and for society and the world without. ${ }^{337}$

B. To what degree is the problem possible of solution by the instruments and technique which we possess at present? Preference should be given to problems of plans other things being equal, which our technique and instruments can reach.

C. What will be the cost? There may be wide variations in cost of problems and plans equally important and equally accessible to scientific investigations.

D. What are the best of the possible agencies for doing the work? ${ }^{338}$

\footnotetext{
337 "Minutes of the Meeting of the Committee on Problems and Plans in Education, 21-22 November 1930, Briarcliff Manor, NY," Box 78, Folder Problems and Plans Committee 1930.

${ }^{338}$ Ibid.
} 


\section{Appendix D - November 1935 issue of Occupation: The Vocational Guidance Magazine briefing in the first meeting of the AYC.}

1. A comprehensive study of the youth problem should be made and a composite picture of it formulated.

2. The contribution of the many agencies at work in this field should be studied and evaluated.

3. As suggested by the cooperating committee of the American Council of Education, a study of the characteristics of youth should be immediately undertaken.

4. The goals of our educational system should be critically evaluated, and desirable objectives set up for the whole field of secondary education.

5. The leisure-time activities of youth must be considered, and definite recommendations made to the people of the United States for the development of programs for leisure in their respective communities.

6. The problems of secondary and general education in rural districts and small towns must be studied, for about two-thirds of all students of high-school age are in schools having an enrollment of 100 or less.

7. An investigation of youth's vocational opportunities and requirements is needed, and should include the types of jobs young people enter, their working conditions and progress in the jobs, and the best training methods for such employment. Consideration should be given "to the possibilities of a much greater differentiation of our entire educational program to meet the varying needs and abilities of American youth."

8. The numerous experiments being carried out and should be examined and their tested results recommended to the people of the country. New experiments should be tried wherever it seems desirable and wise to undertake them. ${ }^{339}$

\footnotetext{
${ }^{339}$ November 1935 Issue of Occupations: The Vocational Guidance Magazine in "Unemployed Youth" Source: Monthly Labor Review 42, no. 1 (January 1936): 74-76. Accessed October 27, 2017. http://www.jstor.org/stable/41814702.
} 


\section{Appendix E: Mayor's Commission Recommendations}

- That the city enacts an ordinance to the effect that no future contracts may be given to any firm or corporation that directly or indirectly discriminates against worker on account of race, creed or color.

- That the New York City Housing Authority be empowered to plan a farsighted housing program for Harlem.

- The authorities of the City of New York enforce the housing code and condemn the dwellings unfit for habitation.

- The city continues to support the legislation for the improvement of housing conditions heretofore recommended by this Commission.

- The Federal Government be requested to provide the necessary funds for the immediate launching of an emergency school building program in Harlem.

- The additional school quarters be secured forthwith - temporary in character if necessary - in order that classes by reduced with all possible speed.

- That every effort is made to secure additional playgrounds in cooperation with churches, the park authorities and welfare agencies.

- That the staff of teachers and especially visiting teachers be adequately increased.

- That the contract system of cleaning the schools be abandoned and that the work is done by City employees.

- That the City direct particular attention, through social and governmental agencies, to the problem of deficient or delinquent children in Harlem.

- That I accordance with the law which prohibits racial discrimination in the tax-supported hospitals, appointment be made to all municipal hospital without regard to race, creed or color and the law be observed or enforced.

- That the police in Harlem be instructed - and violation of these instructions should be followed with disciplinary measures - that it is not their duty to interfere with the association of White and colored citizens.

- That the Commissioner of Police arrange for the appointment of a committee of from five to seven Harlem citizens of both races to whom people may make a complaint if mistreated by the police. ${ }^{340}$

\footnotetext{
${ }^{340}$ Frazier Papers, Box 131-117, Folder 3, 118.
} 


\section{Appendix F - "Declaration of Policy" the American Youth Commission selected proposals:}

29. Rapid and unprecedented development of all forms of higher education during the past two decades, mainly publicly supported higher education, not only reflect the distinctive character of our democratic idealism, but also furnishes conclusive proof of the reality of the long-recognized principle of equality of opportunity in America life. From these institutions have come a large portion of the trained personnel of the established professions and the leadership of our complex industrial and social life. Furthermore, the result of scientific research carried on by such institutions have been of well-nigh incalculable worth to the economic life of the nation. When viewed from these two standpoints along the general scheme of higher education of the country must be regarded as a principal, productive asset, the conservation and further development of which are matter of permanent concern for the States and the nation.

38. The conference notes the critical condition of certain underprivileged groups, particularly the Negroes, and the necessity for special solicitude with regard to them. It is obvious that further diminution of educations facilities of this group would handicap them far in excess of the handicap placed upon other children, and would hazard the possibilities of Negroes participant in our future society with a degree of efficiency commensurate with demands. The attention of the country, therefore, is called to the fact that serious consideration should be given the past and present unequal education opportunities before attempting any further retrenchments. ${ }^{341}$

The first structural foundations of the NYS seen are in an AYC folder from 1932

labeled "The Citizens Conference on the Crisis in Education":

The critical condition of certain underprivileged groups particularly Negroes, and the necessity of special solicitude with regard to them. It is obvious that further diminution of education facilities of this group would handicap them far in excess of the handicap placed upon other children, and would hazard the possibilities of Negroes participating in our future society with a degree of efficiency commensurate with demands. The attention of the country, therefore, is called to the fact that serious consideration should be given the past and present unequal education opportunities before attempting any further retrenchments. ${ }^{342}$

\footnotetext{
341 “Citizens Conference on the Crisis in Education,” Washington, D.C., January 5-6, 1932, 29.

342 "Statement of the Current Situation," Folder: Citizens Conference on the Crisis in Education, Washington, D.C., January 5-6, 1932, NYS Papers, Box 44, 1.
} 


\section{Appendix G - Foundation for Planned NYS}

\section{STATEMENT OF PURPOSE.}

What are the Effects, if any, of their Minority Racial Status upon the Personality Development of the Negro Youth?

10. SPECIFIC OBJECTIVES.

a. To define the principal social types which characterize the personality adjustment of Negro youth to his minority racial status.

b. To analyze the relationship between personality type and social type in Negro youth's racial adjustment.

\section{DELIMINATIORS OF THE PROBLEM.}

a. The brief outline of those aspects of is cultural milieu which appears to have bearing upon his socio-racial adjustment will be examined for location ad understating types of cases that are to be studied intensively rather than to define the community and social organization itself.

b. In this study the personality type will, for the most part, be taken "as given" and it will be studied directly in relationship to the social role of the individual."

\section{DEFINITIONS OF TERMS.}

a. Personality refers to the organization of the individual's traits, habits, and attitude which determine his social role.

b. Social type or social role is meant the social position or function which the individual comes to occupy as a result of interaction with society.

c. Of particular interest in this study... will be an analysis of the person's conception of himself insofar as that is a factor in defining his social role.

\section{DIVISION OF THE STUDY}

\section{A. The Ecological Setting of the Study}

1. A strict sampling of communities based upon ecological indices will be impossible within the time limitation; nevertheless, studies of the following communities will cover a wide range of ecological types:

1. Negro Youth in the Metropolitan North: Chicago: New York. 
2. Negro Youth in the Middle States Urban Communities: Washington; Louisville.

3. Negro Youth in the Plantation and Non-Plantation Rural South.

4. Nero Youth in the Urban South: New Orleans: Natchez.

2. A complete description of the ecological setting within a given community will not be attempted, but enough indices will be presented to give at least a rough characterization of the area.

B. The Background of Community and Social Organization.

This analysis will not be thoroughgoing for any given community but data will be presented which have a special bearing upon the socio-racial factor upon the social position of Negro youth for the purpose: (1) of determining where to secure sample cases for further study; and (2) of providing a brief, general orientation in the broader aspects of the problem. This phase of the study will include two major divisions.

1. Organization of Social Life within the Negro Community Itself.

Attention will be given only to factors involved in whatever social stratification may be present.... In each community toward what values the taboos and mores are directed, especially those that have direct racial significances. Among these value-factors in stratification may be considered items such as the following:

i. Color gradation

ii. Family background.

iii. Educational background

iv. Wealth: (1) secured legally, illegally; status of occupation;

1. Mode of spending; income; property ownership esteemed; etc.

v. Social memberships: cliques; fraternal orders; prestige groups, etc.

vi. Relation to particular mores of responsibility.

2. The Relation of Negro Youth to the Larger Community.

a. What can and cannot the individual do in various inter-racial situations

b. How does the Negro's status within his own community affect his participation in the larger Community life? 


\section{THE SOCIO-RACIAL FACTOR in PERSONALITY DEVELOPMENT}

Greater attention will be given to the central question concerning the development of social types within the personality of Negro Youth will be approached through the use of a number of methods:

1. Life history

2. Data secured through unguided, informal interviews, latter to be organized roughly into categories, such as Color preference, patterns of accommodation in employment, reception, etc.

3. Social case histories secured through social agencies.

4. Psychiatric clinical case records

5. Guided interviewers.

6. Questionnaires.

7. Attitude tests.

8. Distinct problems have appropriate methods.

So as far as possible the type of approach used if any one area will be common to the others.

So far as possible, the types of information sought by the above methods will be parallel. ${ }^{343}$

${ }^{343}$ The NYS Study of the AYC, Frazier Papers, Box 131-106, Folder 5. 


\section{Appendix H - "Personal Attitude Test"}

\section{A selection of questions}

1. It seems as if I never can answer my teacher's questions right.

2. When I get mad I like to beat up everybody who comes near me.

3. They never teach us anything useful in school.

4. It is better to be White than colored.

5. I do not have any good clothes.

6. I wouldn't play with a White girl if I could.

7. I wish I were lighter in color than I am.

8. Sometimes I feel so blue that I'd like to kill myself.

9. Talking to White people scares me.

10. My father spends too much money on liquor.

11. I hate my father

12. I wish I could go away and live someplace else.

13. My Father doesn't amount to much.

14. I always get blamed for everything that goes wrong in class.

15. I hate White people.

16. I wish I were White.

17. I keep away from White girls as much as I can.

18. White girls get a lot more from their folks than I do.

19. My father is too lazy to go out and work.

20. I'd like to beat up the policeman just once.

21. Sometimes I wish I was never born.

22. Praying never did any good.

23. If I could, I would rather play with a White girl than with a colored girl.

24. There are some people I'd like to kill if I could.

25. White people are to blame for my father's being out of a job.

26. I wish we had a better place to play.

27. My father beats my mother.

28. People never want to answer my questions.

29. My teacher isn't fair to me.

30. I wish I were dead.

31. Listening to White people talk makes me mad.

32. Most of the things in the Bible aren't true.

33. I am scared of my father.

34. I am going to get even with White folks when I grow up.

35. I'm not smart enough to get into college.

36. I never get enough to eat at home.

37. Religion is a lot of bunk. ${ }^{344}$

${ }^{344}$ Personal Ratings, Frazier Papers, Box 131-106, Folder 5. 


\section{Appendix I - "Occupational Ratings"}

\begin{tabular}{|l|l|l|l|l|}
\hline Column 1 & Column 2 & Column 3 & Column 4 & Column 5 \\
\hline Field Hand & & $\begin{array}{c}\text { Negroes Cannot do this } \\
\text { job as well as Whites }\end{array}$ & $\begin{array}{c}\text { Negroes Can do } \\
\text { this job as well as } \\
\text { Whites }\end{array}$ & $\begin{array}{c}\text { Negroes Cannot } \\
\text { do this job better } \\
\text { than Whites }\end{array}$ \\
\hline Doctor & & & & \\
\hline $\begin{array}{l}\text { Singer or } \\
\text { Musician }\end{array}$ & & & & \\
\hline Aviator & & & & \\
\hline Policeman & & & & \\
\hline Teacher & & & & \\
\hline
\end{tabular}

${ }^{345}$ Occupational Ratings, Frazier Papers, Box 131-106, Folder 5. 


\section{Appendix J - "Race Attitudes Test"}

A 3-page, 64-question (selection):

1. I think White people could do more for colored people but they won't.

2. Sometimes White people make me mad, but they are no worse than other people.

3. White people call Negroes bad names.

4. White people always take care of Negroes who work harder and minds his own business.

5. All Negroes want from White people is to be left alone.

6. I neither like nor dislike White people.

7. Most White people make fun of Negroes and laugh at them.

8. No matter how nicely he treats a colored person, a White man doesn't really mean it.

9. White people never did me any harm or any good.

10. White people are poor Christians.

11. White people are human and have the fault of other human beings.

12. White people don't treat Negroes any words than other Negroes do.

13. The South was a beautiful place before White people came in and ruined it.

14. The White race had produced some of the best and some of the worst men in history.

15. There are all kind of White people - some are good and some are bad.

16. I'd rather be dead than ask a White man for anything.

17. Negroes should hate all White people.

18. White people have done more for the world than any other race.

19. White people have built up the best civilization in the world.

20. White people are mean and stingy.

21. White people are the cruelest people in the world.

22. Negroes would still be heathen savages if it were not for the White people in educating the and bringing the Christianity.

23. The greatest general in history was a Negro.

24. Negros are the best singers and dancers in the world.

25. If you don't know who did the crime, you can usually bet it was a Negro

26. Negroes have done more for the world than any other people.

27. Negroes always work hard and try to improve themselves.

28. Negroes are the meanest people in the world.

29. Negroes drink too much.

30. Negroes are cowards

31. Negroes would be nice looking fi they didn't have bad hair.

32. The United States couldn't have won any wars without the help of Negroes.

33. Negroes think more about singing and playing around than they do making something of themselves.

34. Some of the best athletes in the world are White and some are Negro.

35. Negroes don't have the courage to fight for their rights. 
36. Negroes are as smart as other people but no smarter.

37. Negro doctors re just as good as doctors of other races.

38. Only a few Negros ever become famous but a large number could if given a chance. ${ }^{346}$

${ }^{346}$ Race Attitudes, Frazier Papers, Box 131-106, Folder 5. 
Appendix K - "Guide for Writing Documents on your Experiences, Thoughts, and Behavior Growing out of the Fact that You are Colored or a Negro"

The nine questions to be asked:

1. Tell how you came to know you were colored or a Negro.... Be sure to tell how old you were when you found out you were colored or a Negro.

2. Tell in story form all your contacts with White people. Be sure to include in your story all the pleasant as well as unpleasant contacts... be sure to describe the Whites and tell specifically what they said and did, a how you felt, what you said and what you did.

3. Write a much as you can remember of your day dreams, past and present especially those in which White and colored persons are concerned.

4. Write all you can remember of your dreams during sleep, especially those in which White and colored people are concerned.

5. Stat frankly how you act and feel when you come in contact with White people.

6. State frankly how you act and feel in regard to colored people of different colors. In this section of your story you should include a description including color, of your closet friend, your pals, members of your clique, your sweetheart, and the husband or wife you wish to marry.

7. Tell in what way you feel handicapped because you are colored or a Negro.

8. By which name do you prefer to be called: colored, Negro, Afro-Amer9can, or any other name, and tell why you prefer the name.

9. Tell what your parents have told you about White people and what you should do in your various relations with them. Tell what you have thought in the past ns what you think today of your parents' advice and whether you have followed their advice and why. ${ }^{347}$

The instruction sheet had thirty questions that appear to call for the interviewee to circle an "A" for agreed and a " $\mathrm{D}$ " for disagree. The questions are informative:

1. We ought to try to mingle with Whites in any social way.

2. The White man has clearly shown the dominance of his race over ours and we should continue for a long time to accept his leadership.

3. Aft her Negro had been educated to the level of the White man he is still inferior to the White man.

4. The Negro should expect to be considered inferior until he gets some property, and votes at election time.

${ }^{347}$ Document Instruction Sheet for Negros to Answer a Questionnaire, Frazier Papers, Box 131-106, Folder 5. 
5. The Nero should support his church and preachers for it is only through them that he can hope to get to Heaven - the place where there is no prejudice.

6. We should not expect White men to be punished when a Negro is lynched who had been accuse of attacking a White woman.

7. Negro men should lynch any White man attacks a Negro woman.

8. The Negro should consider such comedians as Bert Williams and Stepin Fetchit as leaders of their race, because of their popularity with White people.

9. Booker T. Washington, because of his educational plans, was the greatest Negros who ever lived.

10. W.E.B Du Bois ideas that the Negroes should be trained to be teachers, doctors, lawyers, and business men before receiving industrial education was all wrong.

11. We out not to expect full-blooded Negros to rise to positions of first rank in our race, because they are not as intelligent as Negroes of mixed blood,

12. We should expect to find prejudice within our race because of our differences in skin color, and the quality of your hair, just the same as the White man is prejudiced against us on account of these things.

13. Negro newspapers ought to devote their entire time to fighting the White man.

14. Negro newspapers should not use any space saying anything about the White man, either good or bad

15. The Negro should not kick against segregation while having his own schools, churches, and business places.

16. The average black man of wealth and education has as much background of American civilization as the average White man of wealth and education.

17. Only when he had White blood ought the Nero to cry out against mistreatment.

18. We out not to say anything wherever one of our race is killed illegally, for fear of making the White man mad.

19. The Negro should have as many social opportunities as the White, but should be limited in enjoying them to the company of other Negroes.

20. The long-run enjoyed the "Green Pastures" proves that Negro actors are superior to White actors.

21. That Paul Robeson, Fritz Pollard, Duke Slater, Eddie Tolen, DeHart Hubbard, Jessie Owens and other Negroes have been outstanding proves that Negroes are better athlete than White people.

22. Negro poets and novelist should stick to writing about Negroes in their poems and novels.

23. We are inferior to White people not only because we were recently slaves but because we were recently savages.

24. Mulattoes are inferior to blacks because their blood is not as pure as that of blacks.

25. Mulattoes are superior to blacks because their blood is mixed with the blood of the White man.

26. We ought not expect the inferior members of our race treated much better than trained apes. 
27. The natural hatred which the White man has for the black man will forever cause the mulatto to fee that he is better than the black man.

28. The Yellow Negro and the Black Negro out to consider themselves different in intelligence as in color.

29. The undereducated Negro does not break the law as often as the educated Negro.

30. No Negro should hold an office of trust, honor or profit for a long time to come. $^{348}$

${ }^{348}$ Revised Scale for Attitude of Negroes Toward the Negro, Frazier Papers, Box 131-106, Folder 5. 


\section{Appendix L - November 1935 issue of Occupation: The Vocational Guidance}

Minutes of ACE's Committee on Problems and Plans in Education, held November

21-22, 1930, in Briarcliff Manor, NY.

A. What is the relation of the problem or plan to the field of education as a whole? Does it fill a present gap? Three significant inquiry groups were envisioned.

Number I comprise all studies relating to human beings, as they grow and unfold chiefly from within, their interests and aspirations, abilities and disabilities at various stages of life. These studies are based upon psychology, medicine, psychiatry, anthropometry, nutrition, etc.

Number II comprises all studies that relate to the world without in which the individual must find a place, to collect or cooperative life, particular the needs and problems of the new industrial society into w which our world is moving, and the present or prospective freedom, happiness, ad wholesome functioning of the individual in that life. These studies are based on social psychology, anthropology, sociology, economics, law, political sciences, ethics, etc.

Number III comprises all studies relating to the educational process of society, purposed or unpurposed, including the family, church, vocation, press, theatre, monition pictures, libraries, museums, radio, as well as the school, by which the inherent growth of the individual is modified by and for society and the world without. ${ }^{349}$

F. To what degree is the problem possible of solution by the instruments and technique which we possess at present? Preference should be given to problems of plans other things being equal, which our technique and instruments can reach.

G. What will be the cost? There may be wide variations in cost of problems and plans equally essential and equally accessible to scientific investigations.

H. What is the best of the possible agencies for doing the work ${ }^{350}$

\footnotetext{
349 "Problems and Plans in Education."

350 "Problems and Plans in Education."
} 
VITA

\section{RANDALL HAINES KAUFMAN}

2019 Florida International University, Ph.D. in Higher Education

2017 Interim Dean of Faculty and Student Service Miami Dade CollegeHomestead, Florida

2012-2017 American Council on Education (ACE), Evaluator, Washington, D.C.

2005-Present Chair, Humanities and Social Sciences Department, Miami Dade CollegeHomestead, Florida

2004-2005 Dean, National School of Technology, Kendall, Florida

2003-2004 Dean, ITT-Technical College, Chantilly, Virginia

2002-2003 Dean, Key College, Fort Lauderdale, Florida

2002-2003 Social Sciences Coordinator, Georgia Military College, Fort Benning, Georgia

2000-2002 Dean, Georgia Military College, Fort Benning, Georgia

1998-2000 Assistant Director, Georgia Military College, Fort Benning, Georgia

1997-2000 History Instructor, Georgia Military College, Fort Benning, Georgia

1996-1997 Adjunct Instructor, Chattahoochee Community College, Phenix City, Alabama

1995 Dowling College, New York, New York State Teaching Certification 7-12 Social Studies

1994 University of Florida, M.A. in History - Germany, Holocaust, and History of Medicine

1989 University of California at Santa Barbara, B.A. in History-Modern Europe, Judaism, and Coaching Certificate 